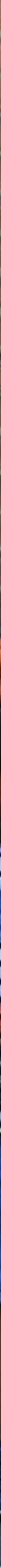

Evaluatie EU Schoolfruit- en groenteprogramma 2018-2019 



\section{Evaluatie EU Schoolfruit- en groenteprogramma 2018-2019}

Angeliek Verdonschot MSc, Anouk Mesch BSc, Prof.dr. Emely de Vet, Dr.ir. Annemien Haveman-Nies

Dit onderzoek werd mede mogelijk gemaakt door financiële steun van:

Het ministerie van Landbouw, Natuur en Voedselkwaliteit en het ministerie van Volksgezondheid, Welzijn en Sport.

Wageningen University \& Research

Wageningen, mei 2020 
Angeliek Verdonschot MSc, Anouk Mesch BSc, Prof.dr. Emely de Vet, Dr.ir. Annemien Haveman-Nies, 2020. Evaluatie EU Schoolfruit- en groenteprogramma 2018-2019. Wageningen, Wageningen University \& Research, Rapport. 72 blz.; 17 fig.; 5 tab.; 70 ref.

Dit rapport is gratis te downloaden op https://doi.org/10.18174/521459.

(C) Wageningen University \& Research, onderdeel van Stichting Wageningen Research, 2020 Alle rechten voorbehouden. Niets uit deze uitgave mag worden verveelvoudigd, opgeslagen in een geautomatiseerd gegevensbestand, of openbaar gemaakt, in enige vorm of op enige wijze, hetzij elektronisch, mechanisch, door fotokopieën, opnamen of enige andere manier zonder voorafgaande schriftelijke toestemming van Wageningen University \& Research.

Foto omslag: Moweena Faber - Roessingh van Iterson (Moweena fotografie) 


\section{Inhoud}

$\begin{array}{ll}\text { Samenvatting } & \mathbf{5}\end{array}$

1

$\begin{array}{ll}\text { Inleiding } & 7\end{array}$

$\begin{array}{lll}1.1 & \text { Gezond eetgedrag bij kinderen } & 7\end{array}$

$\begin{array}{lll}1.2 & \text { Voedseleducatieprogramma's } & 7\end{array}$

$\begin{array}{lll}1.3 & \text { Thuisomgeving } & 8\end{array}$

$\begin{array}{lll}1.4 & \text { Schoolomgeving } & 8\end{array}$

$\begin{array}{lll}1.5 & \text { Doel van het onderzoek } & 8\end{array}$

2

\section{Methode}

2.1 Onderzoeksopzet 11

2.2 Studiepopulatie $\quad 12$

2.3 Procedures $\quad 14$

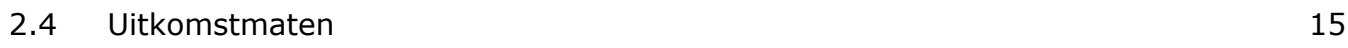

2.4.1 Achtergrondkenmerken 15

2.4.2 Kennis over voeding 15

2.4.3 Groente- en fruitconsumptie 15

2.4.4 Waardering EU-Schoolfruit en Smaaklessen 16

2.4.5 Implementatie van EU-Schoolfruit en Smaaklessen 16

$\begin{array}{ll}2.4 .6 \text { Voedingsbeleid } & 17\end{array}$

2.4.7 Gezondheidsbevorderend gedrag van ouders 17

2.5 Statistische analyses $\quad 19$

$\begin{array}{llr}3 & \text { Resultaten } & \mathbf{2 1}\end{array}$

$\begin{array}{lll}3.1 & \text { Kenmerken van de studiepopulatie } & 21\end{array}$

$\begin{array}{lll}3.2 & \text { Effect op groente- en fruitconsumptie } & 22\end{array}$

$\begin{array}{lll}3.3 & \text { Effect op kennis over gezonde voeding } & 22\end{array}$

3.4 Waardering EU-Schoolfruit en Smaaklessen 23

3.4.1 Waardering EU-Schoolfruit en Smaaklessen van kinderen 23

3.4.2 Waardering EU-Schoolfruit en Smaaklessen van leerkrachten $\quad 24$

3.5 Implementatie EU-Schoolfruit en Smaaklessen $\quad 25$

3.5.1 Implementatie EU-Schoolfruit $\quad 25$

3.5.2 Implementatie Smaaklessen $\quad 26$

$\begin{array}{lll}3.6 & \text { Invloed van voedingsbeleid } & 27\end{array}$

$\begin{array}{lll}3.7 & \text { Invloed van de ouders } & 28\end{array}$

4.1 Samenvatting van de resultaten $\quad 31$

4.2 Discussie van de gevonden resultaten 31

4.2.1 Effect op kennis over voeding $\quad 31$

4.2.2 Effect op groente- en fruitconsumptie 32

4.2.3 Waardering EU-Schoolfruit en Smaaklessen $\quad 32$

4.2.4 Implementatie Smaaklessen $\quad 32$

4.2.5 Invloed van voedingsbeleid 33

4.2.6 Invloed van de ouders $\quad 33$

$\begin{array}{lll}4.3 & \text { Sterke punten en verbeterpunten } & 34\end{array}$

4.4 Conclusie $\quad 34$ 
5.2 Wetenschap

$\begin{array}{ll}\text { Referenties } & 37\end{array}$

Bijlage 1 Vragenlijst voor de kinderen (groep 6-8)

Bijlage 2 Resultaten voor het effect van EU-Schoolfruit en Smaaklessen op GF consumptie op de korte- en lange termijn voor de totale populatie $(n=1386)$

Bijlage 3 Resultaten voor het effect van EU-Schoolfruit en Smaaklessen op kennis op de korte- en lange termijn voor de totale populatie $(n=1386)$

Bijlage 4 Resultaten voor het effect van EU-Schoolfruit en Smaaklessen op GF consumptie in de verschillende categorieën van voedingsbeleid op de korte- en lange termijn voor de totale populatie $(n=1386)$

Bijlage 5 Resultaten voor het effect van EU-Schoolfruit en Smaaklessen op GF consumptie in de verschillende categorieën van GBG op de korte- en lange termijn voor de totale populatie $(n=1386)$ 


\section{Samenvatting}

\section{EU-Schoolfruit en Smaaklessen}

EU-Schoolfruit, ontwikkeld in 2009 en gefinancierd door de Europese Unie, stimuleert kinderen samen in de klas groente en fruit te eten. Deelnemende scholen ontvangen 20 weken lang iedere week 3 porties groente en fruit voor alle kinderen. Het lesprogramma Smaaklessen, ontwikkeld in 2006 door het Voedingscentrum en Wageningen University \& Research, heeft als doel om de interesse en kennis over voeding te verhogen en streeft ernaar dat alle kinderen voedselvaardig worden. De volgende vijf thema's komen daarbij aan bod: 'smaak', 'gezond eten', 'voedselproductie', 'voedselvaardigheden' en 'koken'. Voor elke groep zijn er 5 lessen en leraren kunnen deze lessen flexibel inzetten.

\section{Evaluatiestudie}

Een grootschalige effectmeting met ruim 1300 leerlingen is uitgevoerd in de periode september 2018 - november 2019, om het effect te onderzoeken van EU-Schoolfruit alleen en in combinatie met Smaaklessen, op het kennisniveau over voeding en groente- en fruitconsumptie bij kinderen (7-12 jaar) in groep 6-8 van de basisschool. Daarbij werd ook nagevraagd in welke mate de programma's werden gewaardeerd en hoe de programma's werden ingezet. Ook is er gekeken naar de invloed van de schoolomgeving (het voedingsbeleid van de scholen) en de thuisomgeving (het gezondheidsbevorderend gedrag van de ouders) op het effect van de programma's.

\section{Effect van EU-Schoolfruit en Smaaklessen}

EU-Schoolfruit en Smaaklessen bleken geen effect te hebben op de groente- en fruitconsumptie van de kinderen. Wel aten kinderen na deelname aan EU-Schoolfruit op de korte termijn iets meer groente en fruit dan kinderen die niet deelnamen aan het programma. Een effect was te zien in de kennis over voeding. Terwijl alle kinderen gedurende de tijd kennis opdeden over voeding, verbeterde dit in de groep die EU-Schoolfruit in combinatie met Smaaklessen ontving sterker dan in de groepen die Smaaklessen niet ontvingen. Een half jaar nadat het programma was afgelopen was dit effect nog steeds zichtbaar.

\section{Proces uitkomsten}

Leerlingen en leraren bleken enthousiast over zowel EU-Schoolfruit als Smaaklessen. Hierbij werd EUSchoolfruit hoger gewaardeerd door leerlingen wanneer ook Smaaklessen werd ingezet. Bij Smaaklessen deden vooral 'proeven', 'experimenten' en 'koken' het goed. EU-Schoolfruit werd ingezet in de ochtendpauze, waarbij leerlingen zelf kozen welk fruit ze wilden eten. Op scholen waar ook Smaaklessen werd gegeven, zetten leerkrachten gemiddeld 2.9 (van de totaal 5) lessen in en de lessen over zintuigen en de productiewijze werden het vaakst ingezet. Het aantal uitgevoerde lessen was positief geassocieerd met het kennisniveau van de kinderen.

\section{Invloed schoolbeleid en thuisomgeving}

Naast het effect van de programma's op groente- en fruitconsumptie en kennis over voeding bij kinderen is er ook gekeken naar invloed van het voedingsbeleid op school en het gezondheidsbevorderend gedrag (GBG) van de ouders/verzorgers. Verschillende omgevingsfactoren bleken van invloed op het effect van de schoolprogramma's. Kinderen op scholen zonder voedingsbeleid hadden de grootste verandering in groente- en fruitconsumptie als gevolg van EUSchoolfruit. Op scholen met voedingsbeleid was er weinig effect van de programma's op groente- en fruitconsumptie. Wanneer ouders vaak gezonde snacks meegaven aan hun kind naar school en gezond eten in de thuisomgeving stimuleerden, was de groente- en fruitconsumptie van kinderen ook hoger dan wanneer dit weinig gebeurde. 


\section{Conclusie}

EU-Schoolfruit in combinatie met Smaaklessen is effectief in het verhogen van kennis over gezonde voeding, maar niet in het verhogen van groente- en fruitconsumptie bij kinderen. Wel zagen we dat de programma's kunnen bijdragen aan een toename in groente- en fruitconsumptie bij kinderen op scholen waar nog geen voedingsbeleid wordt ingezet, en bij kinderen uit een thuisomgeving waarbij gezond eetgedrag weinig gestimuleerd wordt. 


\section{$1 \quad$ Inleiding}

\subsection{Gezond eetgedrag bij kinderen}

Gezonde voeding speelt een belangrijke rol in de groei en ontwikkeling van kinderen $(1,2)$. Een gezond voedingspatroon bevat fruit, groente, peulvruchten, noten, volkoren graanproducten en een kleine hoeveelheid aan producten die in hoge mate energie, vet, toegevoegde suikers en zout bevatten (3). Het Voedingscentrum adviseert dat kinderen in de leeftijdsgroep van 9-12 jaar dagelijks 150-200 gram groente en 2 porties fruit zouden moeten eten om aan de Nederlandse richtlijnen voor een gezond voedingspatroon te voldoen (4). Echter laten cijfers van het Centraal Bureau Statistiek zien dat slechts $24.6 \%$ van de kinderen van 8 tot 12 jaar voldoende fruit en $33.5 \%$ voldoende groente eet (5). Om het voedingspatroon van kinderen te verbeteren moeten kinderen aangemoedigd worden om meer groente en fruit te eten.

Scholen zijn een geschikte omgeving voor kinderen om te leren over gezonde voeding en om gezond eetgedrag aan te leren (6). Kinderen met verschillende sociaal-economische achtergronden worden op school bereikt (7). Bovendien biedt de school een educatieve leeromgeving waarin kinderen kennis en vaardigheden opdoen $(8,9,10)$. De fysieke omgeving, gedragsregels en de lesstof hebben potentie om de gezondheid van kinderen positief te beïnvloeden (11). Daarnaast kunnen leerkrachten als rolmodel fungeren voor de kinderen en lessen die geleerd zijn op school kunnen ook buiten school ingezet worden, zoals in de thuisomgeving (24). De thuisomgeving kan betrokken worden door huiswerkopdrachten, of het bespreken van de opdrachten die zijn uitgevoerd op school.

\subsection{Voedseleducatieprogramma's}

Om gezonde voeding bij kinderen meer onder de aandacht te brengen zijn er de afgelopen decennia wereldwijd voedseleducatieprogramma's voor basisscholen ontwikkeld en geëvalueerd $(24,25)$. In de afgelopen decennia zijn in Nederland het EU-Schoolfruitprogramma en Smaaklessen ontwikkeld, waarbij EU-Schoolfruit gericht is op het aanbod van groente en fruit op school en Smaaklessen op het aanbieden van lessen aan over gezonde voeding (zie Figuur 1). Nationale en internationale studies naar de effecten van voedseleducatieprogramma's laten veelal een toename in kennis over voeding zien (12-23). Er is echter weinig bewijs of deze toename in kennis ook daadwerkelijk leidt tot een gezonder voedingspatroon onder kinderen. Daarnaast is het moeilijk om de effecten van de verschillende voedseleducatieprogramma's met elkaar te vergelijken aangezien elk programma zijn eigen aanpak en inhoud heeft. Naast individuele factoren zoals kennis over voeding, hebben ook omgevingsfactoren een belangrijke invloed op de voedselkeuzes van kinderen en hun ouders en de eetpatronen die zij ontwikkelen (26). De impact van de omgeving op gezond eetgedrag is vaak niet meegenomen in evaluaties van voedseleducatieprogramma's $(24,25)$. Omgevingsfactoren zoals de beschikbaarheid, toegankelijkheid en betaalbaarheid van gezonde producten (met name groente en fruit) kunnen bijdragen aan een gezond eetpatroon, waarbij de keuze voor gezonde producten gemakkelijk gemaakt wordt (27). Daarnaast laten andere studies zien dat voedseleducatieprogramma's die zowel individuele als omgevingsfactoren meenemen tot hogere groente- en fruitconsumptie (GF consumptie) leiden $(28,29,30)$. Dit gegeven verschuift de aandacht van individuele factoren (zoals kennis, voedselvaardigheden en motivatie) naar een bredere aanpak waarbij de sociale en fysieke omgeving van kinderen mee wordt genomen (26). Voor kinderen betreft dit voornamelijk de thuis- en schoolomgeving. 


\subsection{Thuisomgeving}

Wat de beschikbaarheid van gezond eten betreft, zijn kinderen grotendeels afhankelijk van hun ouders. Ouders doen de boodschappen en bepalen wat kinderen in de thuisomgeving eten. Onderzoek laat zien dat Nederlandse kinderen in de leeftijdscategorie van 4-12 jaar 59\% van hun fruit en 96\% van hun groente consumptie thuis eten en $36 \%$ van hun fruit en $2 \%$ van hun groente op school (31). Een ander literatuuronderzoek geeft aan dat een stimulerende thuisomgeving positief geassocieerd is met GF consumptie van kinderen (32). Hierin werd een stimulerende thuisomgeving omschreven als een omgeving waar groente en fruit beschikbaar zijn, ouders positieve rolmodellen zijn en waar kinderen aangemoedigd worden om groente en fruit te eten (32). Verschillende studies adviseren om ouders actief te betrekken bij voedseleducatie $(33,34)$. In de praktijk zijn ouders vaak passief betrokken bij voedseleducatieprogramma's via nieuwsbrieven, flyers en thuiswerkopdrachten (33). Tot op heden is de betrokkenheid van ouders alleen in de schoolomgeving meegenomen in evaluatiestudies over voedseleducatieprogramma's en is de thuisomgeving achterwegen gelaten (35).

\section{$1.4 \quad$ Schoolomgeving}

Naast de thuisomgeving speelt de schoolomgeving een belangrijke rol in het bevorderen van gezond eetgedrag bij kinderen. Voedingsbeleid kan een stevige basis leggen voor een gezonde schoolomgeving (36). Verschillende onderzoeken concluderen namelijk dat een voedingsbeleid op scholen positief geassocieerd is met het voedingspatroon van kinderen $(37,38,39)$. Een recente studie over voedingsbeleid op scholen binnen Europa (40) concludeert dat hierbij meerdere soorten beleid gecombineerd moeten worden om gezond eetgedrag bij kinderen te bevorderen. De verschillende soorten beleid die genoemd worden zijn: 1) het verstrekken van gezonde voeding, 2) het verminderen van de beschikbaarheid van ongezonde voeding, 3) het beperken van marketing over ongezonde voeding en 4) het promoten van voedseleducatie. Aansluitend werd genoemd dat het succes afhankelijk is van samenhang van berichtgeving en betrokkenheid van alle stakeholders en sectoren.

\subsection{Doel van het onderzoek}

Bovenstaande studies laten zien dat er veel is bereikt met voedseleducatieprogramma's gericht op educatie over gezonde voeding en groente en fruit aanbod, maar dat er nog verdere winst te behalen is. Het combineren van programma's kan leiden tot sterkere effecten en ook het ontwikkelen van schoolbeleid en het betrekken van de thuisomgeving kunnen een belangrijke invloed hebben op de kennis over en het gedrag ten aanzien van GF consumptie. Hierbij kunnen verschillende soorten voedingsbeleid elkaar versterken. Het doel van huidige onderzoek is:

1. het onderzoeken van het effect van het aanbieden van groente en fruit op school (d.m.v. EUSchoolfruit) al dan niet in combinatie met voedseleducatie (d.m.v. Smaaklessen) op het kennisniveau en de groente- en fruitconsumptie van kinderen in groep 6-8 (7-12 jaar) van de basisschool (zie Figuur 1).

2. het onderzoeken van de invloed van het huidige voedingsbeleid op school en het gezondheidsbevorderend gedrag van ouders/verzorgers op de effecten van beide programma's. 


\section{EU-Schoolfruit}

EU-Schoolfruit is een Nederlands voedseleducatieprogramma voor basisscholen en is ontwikkeld in 2009. EU-Schoolfruit stimuleert kinderen samen in de klas groente en fruit te eten. Deelnemende scholen ontvangen 20 weken lang iedere week 3 porties groente en fruit voor alle kinderen. Aanvullend wordt educatie aangeboden en worden scholen gestimuleerd een schoolfruitbeleid op te stellen. Het programma wordt gefinancierd door de Europese Unie. De afgelopen drie jaar deden er jaarlijks ongeveer 3000 scholen mee (41).

\section{Smaaklessen}

Smaaklessen is ontwikkeld in 2006 en is een Nederlands voedseleducatieprogramma voor basisscholen. Het programma heeft als doel om interesse en kennis over voeding bij kinderen te verhogen en dat alle kinderen voedselvaardig worden, zodat ze gezonde en bewuste keuzes kunnen maken. De lessen zijn gestructureerd in vijf thema's: 'smaak', 'gezond eten', 'voedselproductie', 'voedselvaardigheden' en 'koken'. Er zijn in totaal 5 lessen voor elke groep en leraren kunnen deze lessen flexibel inzetten, wanneer het hen het beste uitkomt. 75\% van de scholen in Nederland maakt gebruik van het aanbod van Smaaklessen (42).

\section{Figuur 1} Omschrijving van EU-Schoolfruit en Smaaklessen. 


\section{$2 \quad$ Methode}

\subsection{Onderzoeksopzet}

Om het effect van EU-Schoolfruit en EU-Schoolfruit in combinatie met Smaaklessen te meten, is in dit onderzoek gebruik gemaakt van een quasi-experimentele studieopzet (zie Figuur 2), waarbij de interventiegroepen bestonden uit scholen die de intentie hadden om het EU-Schoolfruitprogramma uit te voeren en de controlegroep uit scholen die deze intentie niet hadden. Het onderzoek is uitgevoerd bij 1460 kinderen van 69 klassen uit groep 6-8 van 37 basisscholen verspreid over Nederland. Groep 8 is tijdens de eerste twee metingen (T0 en T1) niet meegenomen om de drop-out te beperken, aangezien deze kinderen de basisschool verlaten hebben tijdens de derde meting (T2). In een voormeting (TO) aan het begin van schooljaar 2018/2019 is de uitgangssituatie gemeten. Een eerste nameting (T1) vond plaats in de laatste weken van EU-Schoolfruit om het directe effect vast te stellen. Ongeveer een half jaar na afloop van EU-Schoolfruit is een tweede nameting (T2) uitgevoerd om het effect op de lange termijn te toetsen. De controlescholen zijn gematched met de interventiescholen, op basis van groep en regio. Het effect van EU-Schoolfruit en Smaaklessen is gemeten door veranderingen in GF consumptie en kennis over voeding onder de kinderen van de interventiegroepen te vergelijken met de veranderingen van de controlegroep. Daarnaast is er naar voedingsbeleid gekeken (T1 en T2) en het gezondheidbevorderend gedrag van de ouders (T0, T1 en T2).

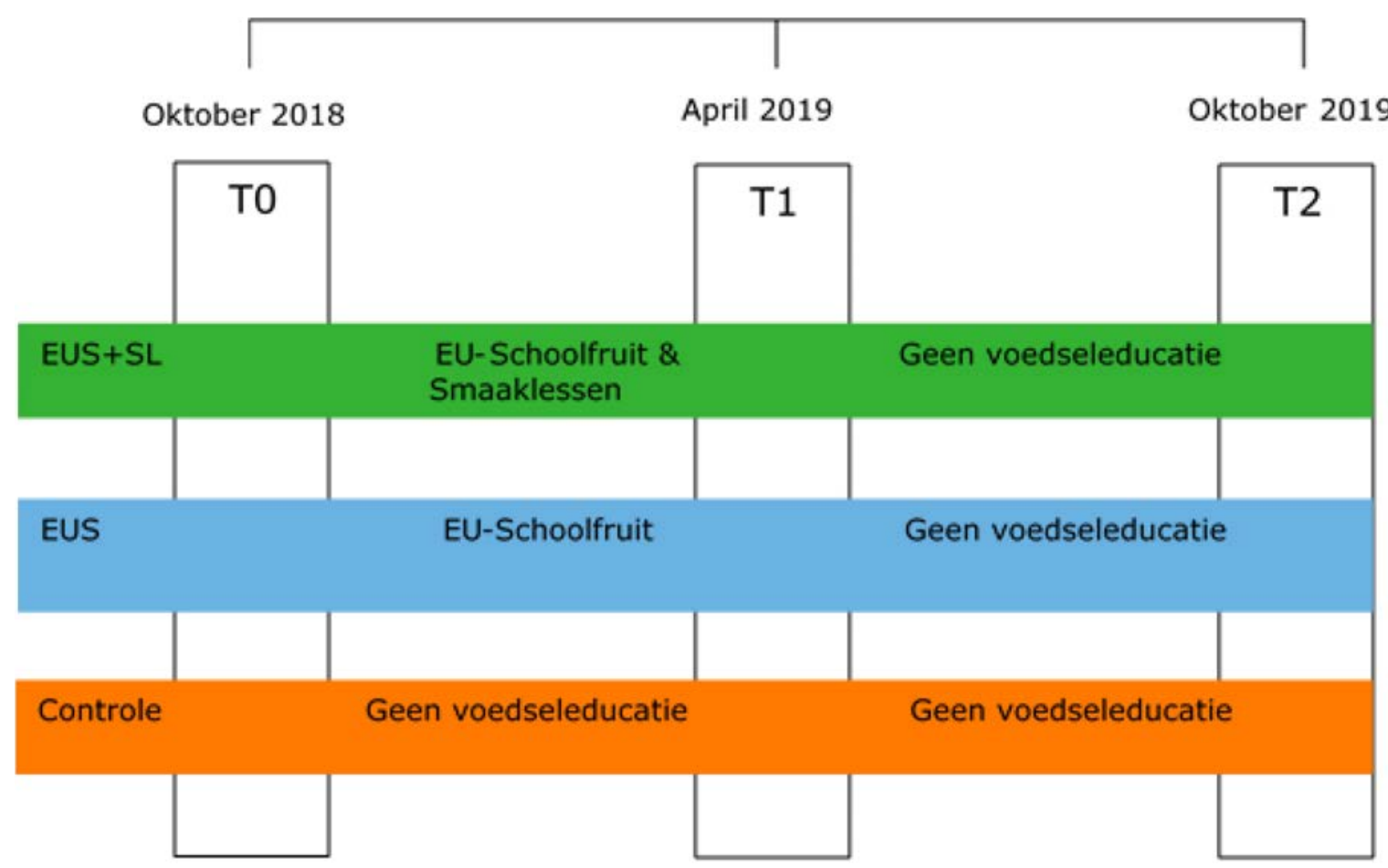

Figuur 2 Gehanteerde onderzoeksopzet bij de effectmeting van EU-Schoolfruit. 


\subsection{Studiepopulatie}

Met informatie van een eerder uitgevoerde effectstudie van Smaaklessen is een noodzakelijke omvang van de studiepopulatie vastgesteld (43). Hierbij is rekening gehouden met de multilevel structuur van het onderzoek, waarbij rekening wordt gehouden met de mogelijke impact van school en klas op de scores van de kinderen. Op basis van eerdere berekeningen zou de effectstudie ongeveer 600 kinderen in de interventiegroep en 600 in de controlegroep moeten hebben om volwaardige analyses uit te kunnen voeren.

Nadat de ethische commissie van Wageningen University \& Research het onderzoek heeft goedgekeurd is de werving gestart. De interventiegroepen (EUS groep en EUS+SL groep) zijn geworven via een oproep in de nieuwsbrief van EU-Schoolfruit, een oproep op de website van zowel EU-Schoolfruit en Smaaklessen en op social media van beide programma's. Scholen werden geïncludeerd in de EUS+SL groep wanneer ze de intentie hadden om mee te doen aan EU-Schoolfruit, in de voorgaande twee jaar Smaaklessen hadden ingezet, de intentie hadden om Smaaklessen in te zetten in schooljaar 2018/2019 en niet van plan waren andere voedingsinterventies in te zetten. Scholen werden geïncludeerd in de EUS groep wanneer ze de intentie hadden om mee te doen aan EU-Schoolfruit, de voorgaande twee jaar geen Smaaklessen hebben ingezet en niet de intentie hadden om Smaaklessen of andere voedingsinterventies in te zetten in schooljaar 2018/2019. 35 scholen hebben zich vrijwillig aangemeld voor deelname aan de effectmeting. Drie scholen konden niet deelnemen in verband met het aanbieden van speciaal onderwijs, wat resulteerde in 32 scholen die voldeden aan de inclusiecriteria voor de EUS en/of EUS+SL groep. Vier scholen hebben zich teruggetrokken in verband met te weinig tijd. Daarnaast zijn twee deelnemende scholen tijdens de effectmeting gefuseerd tot een school en zijn daarom in de analyses als een school gerekend. Dit resulteerde in 27 scholen voor de interventiegroep, waaronder 15 scholen (557 kinderen) in de EUS+SL groep en 12 scholen (474 kinderen) in de EUS groep (zie Figuur 3).

De controlegroep is geworven met behulp van een lijst met alle basisscholen in Nederland $(n=6417)$ (44). Van deze lijst zijn 260 willekeurige scholen geselecteerd. Van die lijst zijn 128 scholen verwijderd aangezien die ooit aan EU-Schoolfruit en Smaaklessen hebben meegedaan. Vervolgens zijn de overige 132 scholen gebeld voor deelname aan de effectmeting. Scholen konden niet meedoen wanneer ze de intentie hadden om andere voedingsinterventies in te zetten, zoals 'Ikeethetbeter' van Albert Heijn of 'Lekker Fit!'. De meestvoorkomende redenen voor geen deelname waren een gebrek aan tijd en deelname aan een ander vergelijkbaar voedseleducatieprogramma. Tien van de 132 benaderde scholen waren bereid deel te nemen in de controlegroep en voldeden aan de inclusiecriteria (7.58\%). De controlegroep bestond aan het begin van de effectmeting uit 10 scholen en 429 kinderen. Met uitzondering van drie provincies (Zeeland, Flevoland en Friesland) zijn alle provincies betrokken bij deze studie (zie Figuur 4).

Nadat er voldoende scholen geworven waren, is er een mail gestuurd naar alle deelnemende leerkrachten met informatie over het onderzoek en een voorstel voor een datum voor het eerste schoolbezoek. Daarnaast ontvingen alle leerkrachten zowel digitaal als schriftelijk een informatiebrief voor de ouders/verzorgers van alle deelnemende kinderen. Deze informatiebrief bevatte informatie over het onderzoek en een formulier met antwoordenvelop die ze konden invullen en terugsturen naar Wageningen Universiteit indien ze bezwaar hadden voor deelname van hun kind. De ouders/verzorgers konden ook een mail naar de hoofdonderzoeker (A. Verdonschot) sturen met bezwaar voor deelname van hun kind. In totaal hebben 14 ouders bezwaar gemaakt voor deelname van hun kind. 

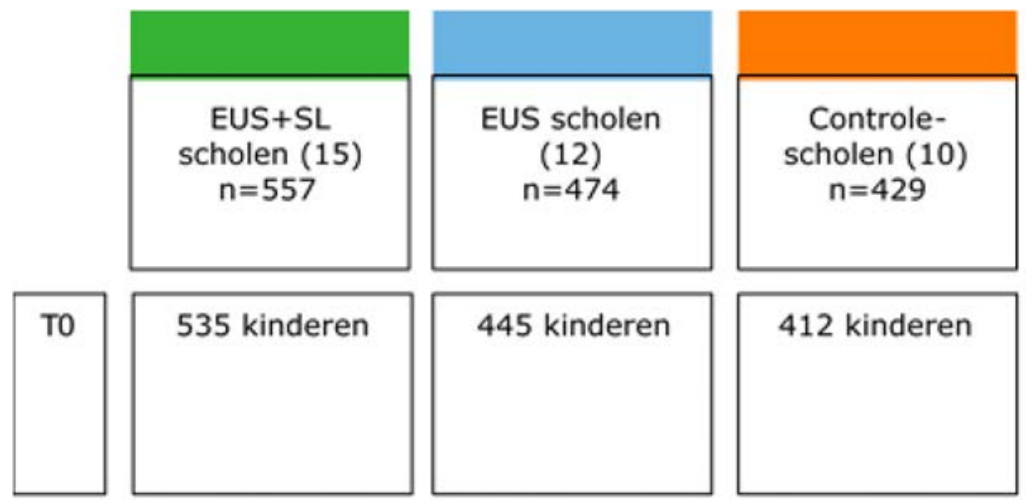

Geen toestemming van

ouders $n=14$

Onvoltooide vragenlijsten

$(<75 \%) n=7$

Uitschieters GF consumptie
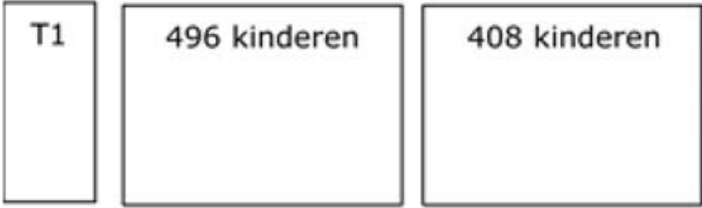

371 kinderen

117 kinderen afwezig tijdens eerste nameting ( $\mathrm{T} 1$ )
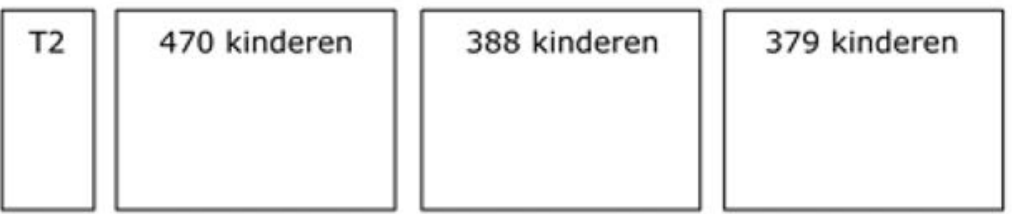

155 kinderen afwezig tijdens tweede nameting ( $T 2$ )

Figuur 3 Aantal deelnemende scholen en kinderen per meeting weergegeven voor de interventiegroepen en controlegroep.

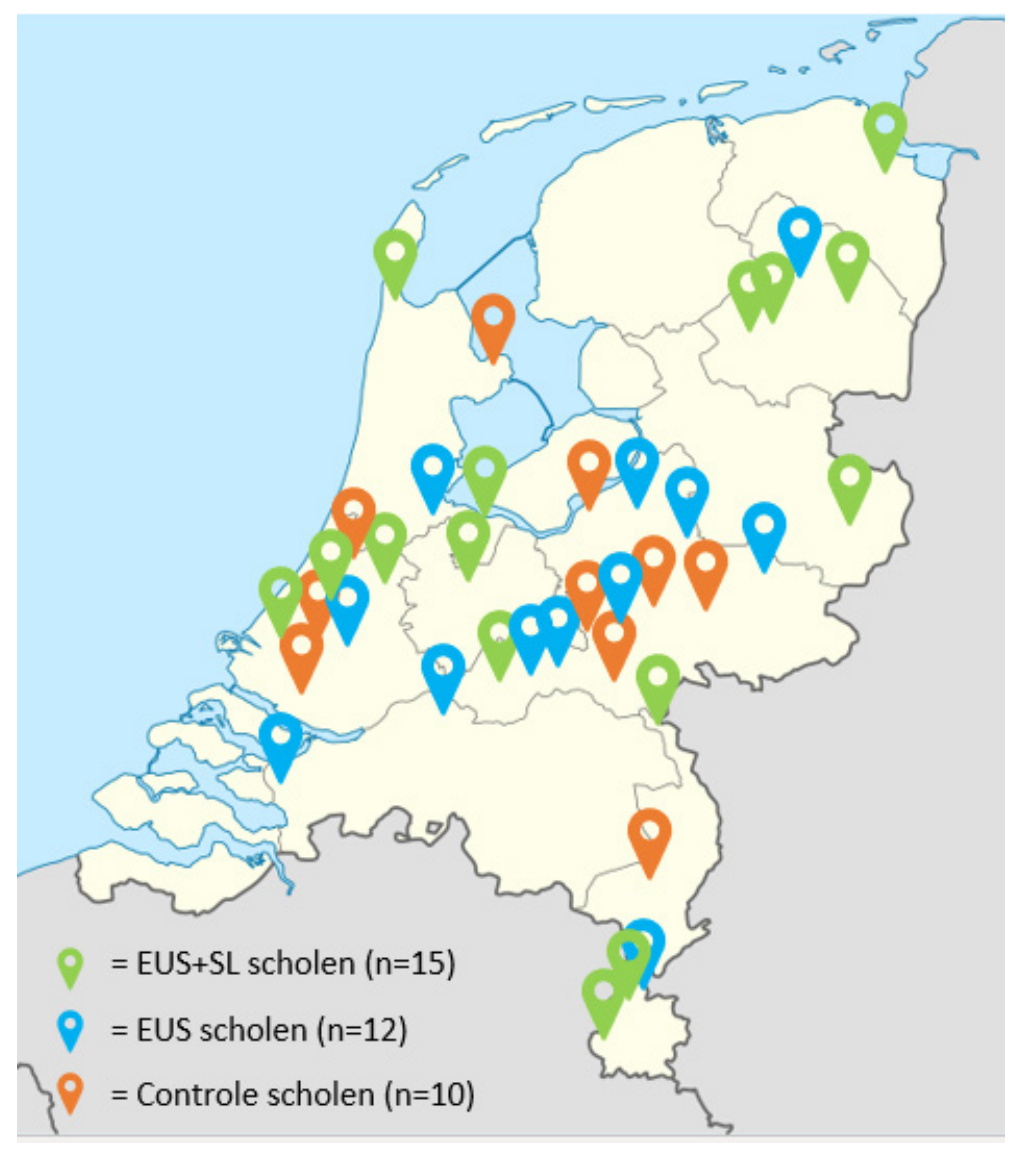

Figuur 4 Verspreiding van deelnemende scholen van de effectmeting in Nederland. 


\subsection{Procedures}

De voormeting (TO) vond plaats aan de start van schooljaar 2018/2019 (oktober t/m november 2018). In deze twee maanden heeft het onderzoeksteam alle deelnemende scholen bezocht ( 1 onderzoeker per school) om de kinderen van groep 6 en 7 een schriftelijke vragenlijst in te laten vullen (zie Bijlage 1 voor de vragenlijst). Scholen met vier deelnemende klassen werden bezocht door twee onderzoekers, zodat meerdere klassen tegelijkertijd de vragenlijst in konden vullen. De onderzoeker gaf een korte introductie van ongeveer 5 minuten over hoe de vragenlijst ingevuld moest worden, waarna de kinderen in klassikale setting zelfstandig de vragenlijst invulden. Het invullen van de vragenlijst duurde ongeveer 30 minuten. De ingevulde vragenlijsten zijn aan het eind zoveel mogelijk gecontroleerd op volledigheid.

Naast de vragenlijst voor de kinderen, was er ook een kortere vragenlijst voor de leerkrachten. De leerkrachten konden deze vragenlijst invullen wanneer de kinderen ook bezig waren met hun vragenlijst. Voor de leerkrachten duurde het ongeveer 10 minuten om de vragenlijst in te vullen tijdens de eerste meting (T0) en ongeveer 20 minuten tijdens de twee daaropvolgende metingen (T1 en T2).

De leerkrachten van de EUS+SL groep werden verzocht om vijf lessen van Smaaklessen met hun groep 6 en 7 uit te voeren in de periode dat EU-Schoolfruit plaatsvond (november 2018 - april 2019). De leerkrachten van de EUS groep werden verzocht om geen voedseleducatie in te zetten met hun groep 6 en 7, en wel mee te doen aan EU-Schoolfruit (zie Figuur 1). Op deze manier werd er een duidelijk onderscheid gemaakt tussen voedseleducatie (Smaaklessen) en de beschikbaarheid en toegankelijkheid van groente en fruit (EU-Schoolfruit). De leerkrachten uit de controlegroep werden verzocht om gedurende het hele onderzoek geen voedseleducatie in te zetten bij hun groep 6 en 7. Nadat dit was uitgelegd tijdens de werving, hebben de leerkrachten nogmaals deze informatie via een schriftelijke brief en een email ontvangen.

De eerste nameting (T1) vond plaats aan het einde van de looptijd van EU-Schoolfruit, zodat het directe effect van het programma getoetst kon worden (april 2019). Ook werden er op dit meetmoment twee pagina's toegevoegd aan de vragenlijst voor de kinderen waarmee hun waardering werd gemeten van EU-Schoolfruit (EUS groep en EUS+SL groep) en Smaaklessen (EUS+SL groep). Daarnaast werd de leerkrachtenvragenlijst aangevuld met vragen over hun waardering van de programma's en het voedingsbeleid op school. Voor de controlegroep waren alleen de vragenlijsten voor de leerkrachten aangevuld met vragen over voedingsbeleid, aangezien er geen voedseleducatie was ingezet.

De tweede nameting (T2) vond plaats in het begin van schooljaar 2019/2020 (oktober t/m november 2019) waarbij zowel de kinderen als de leerkrachten weer dezelfde vragenlijst invulden, maar waarbij er werd gevraagd naar het voedingsbeleid in het lopende schooljaar 2019/2020. Vragen over de waardering van de programma's zijn in deze laatste meting weggelaten. 


\section{$2.4 \quad$ Uitkomstmaten}

\subsubsection{Achtergrondkenmerken}

Kenmerken van de kinderen, leerkrachten en de school zijn gemeten met verschillende vragenlijsten. In de kinderenvragenlijst zijn vragen opgenomen over leeftijd (in jaren), geslacht en in welke groep ze zitten. In de vragenlijst voor de leerkrachten zijn vragen opgenomen over leeftijd, geslacht, het aantal jaar ervaring als leerkracht, het aantal jaar werkzaam op de school en de grootte van de school. Daarnaast is de sociaal-economische positie (SEP) van de buurt van de school weergegeven, afkomstig uit gegevens van het Sociaal en Cultureel Planbureau (45). De SEP is gemeten in waardes van $<0$ (relatief hoog) tot $>0$ (relatief laag) en zijn gebaseerd op opleidingsniveau, inkomen en werkstatus van huishoudens binnen gebieden met een bepaalde postcode. De grondslag, grootte en de plaats van de scholen zijn afkomstig van gegevens van DUO (44).

\subsubsection{Kennis over voeding}

Om het effect van zowel EU-Schoolfruit als Smaaklessen te meten is onder andere kennis over voeding onder de kinderen gemeten. In de vragenlijst voor de kinderen zijn vragen uit eerder onderzoek met Smaaklessen meegenomen (43), en aangevuld met vragen uit een andere vragenlijst waarmee kennis over voeding gemeten wordt (46). In overeenkomst met de leerdoelen van Smaaklessen zijn de volgende zes componenten van kennis over voeding gemeten ( $n=$ aantal vragen in de vragenlijst): 1) gezonde voedingskeuzes $(n=5)$, de 'Schijf van Vijf' $(n=3)$, aanbevolen porties $(n=6)$, vitamines en mineralen $(n=5)$, zintuigen $(n=3)$ en productiewijze $(n=2)$. De juiste antwoorden kregen een score van 1 en de foute antwoorden en de 'weet ik niet' antwoorden kregen een score van 0 . Van elk component $(n=6)$ is een gemiddelde berekend. De scores variëren van 0 (alle antwoorden fout) tot een 6 (alle antwoorden goed).

\subsubsection{Groente- en fruitconsumptie}

De GF consumptie van alle kinderen is gemeten door te meten wat de kinderen de dag van tevoren hebben gegeten aan groente en fruit met behulp van een gevalideerde 24 -uurs recall (47). Deze 24-uurs recall is gebaseerd op eerder onderzoek waarin validatie aantoonde dat dit een valide methode is om GF consumptie van kinderen in kaart te brengen.

De 24-uurs recall deed navraag naar de GF consumptie van de voorgaande (school) dag en werd uitgevoerd op dinsdag tot en met vrijdag. De methode deed navraag naar de consumptie tijdens drie dagdelen en zes eetmomenten: ochtend (ontbijt en ochtend snack), middag (lunch en middag snack) en avond (avondeten en avond snack). Elk dagdeel begon met twee vragen: 1) of er iets gegeten was en 2) of daar groente en/of fruit bij zat. Beide vragen konden beantwoord worden met ja of nee. Deze vragen hadden als doel om het kind na te laten denken over hun daadwerkelijke consumptie gedurende de voorgaande dag. Vervolgens werden de kinderen gevraagd om de groente- en fruitsoorten en de hoeveelheid in een voorgecodeerde tabel in te vullen (zie Figuur 5). Als hun groente- en/of fruitsoort niet in de tabel stond, konden ze dit zelf invullen in de lege ruimtes in dezelfde tabel.

De antwoorden van de 24-uurs recall zijn omgerekend naar grammen op dezelfde manier als in de literatuur (47). Peulvruchten, noten, fruitsappen en smoothies zijn niet meegenomen in de berekeningen. Soepen en groentes als onderdeel van een complete maaltijd (bijvoorbeeld 'boerenkool') zijn wel meegenomen. Om de hoeveelheden om te rekenen naar grammen is gebruik gemaakt van een portiegrootte bestand (48). Wanneer er geen specifiek soort groente of fruit was genoteerd werd de meest voorkomende soort aangehouden (bijvoorbeeld 'bonen'), gebaseerd op de Nederlandse Voedsel Consumptie Peiling (VCP) (49). Deze VCP gegevens zijn ook gebruikt om een portiegrootte passend bij leeftijd en geslacht in te schatten wanneer een bepaalde soort groente en/of fruit genoteerd was zonder de hoeveelheid of portiegrootte te vermelden. 
Voor soepen en gemengde groente maaltijden is het percentage groente per gerecht geschat op basis van de NEVO online recepten database (50). Een omrekening gebaseerd op dit percentage van het totaal aantal grammen van de maaltijd resulteerde in een geschat aantal grammen groente in de maaltijd. Binnen het onderzoeksteam zijn alle codeerafspraken besproken en in een gedeeld document bijgehouden zodat het hele onderzoeksteam alle resultaten (T0, T1 en T2) op een consistente manier kon verwerken.

\begin{tabular}{|c|c|c|c|c|c|}
\hline \multicolumn{3}{|c|}{ Fruit in de ochtend } & \multicolumn{3}{|c|}{ Groente in de ochtend } \\
\hline Appel & .............. & Stuk & Komkommer & f............ & Schijfjes \\
\hline Banaan & n............. & Stuk & Snoeptomaatje & ............... & Stuks \\
\hline Mandarijn & $\ldots \ldots \ldots \ldots$ & Stuk & Paprika & ............... & Reepjes \\
\hline Druiven & ..., $\ldots \ldots$ & Handje & Wortel & $\ldots \ldots \ldots \ldots$ & Stuk \\
\hline Gesneden fruit & f............. & Bakje & Gesneden groente & f............. & Bakje \\
\hline …........ & $\ldots \ldots \ldots \ldots$ & ........ & ............. & .............. & ........ \\
\hline n............. & .............. & ......... & n............. & n............. & $\ldots \ldots \ldots$ \\
\hline$\ldots \ldots \ldots \ldots$ & $\ldots \ldots \ldots \ldots$ & .......... & $\ldots \ldots \ldots \ldots$ & $\ldots \ldots \ldots \ldots$ & ......... \\
\hline$\ldots \ldots \ldots \ldots \ldots$ & $\ldots \ldots \ldots \ldots \ldots$ & .......... & $\ldots \ldots \ldots \ldots$ & $\ldots \ldots \ldots \ldots, \ldots$ & \\
\hline
\end{tabular}

Figuur 5 Een van de voorgecodeerde tabellen uit de vragenlijst voor kinderen.

\subsubsection{Waardering EU-Schoolfruit en Smaaklessen}

Tijdens de eerste nameting (T1) zijn vragen toegevoegd aan de bestaande vragenlijst voor de kinderen $(n=18)$ en de leerkrachten $(n=15)$ uit de EUS- en EUS+SL groep om hun waardering van EU-Schoolfruit in kaart te brengen. Aspecten die gemeten zijn waren onder andere hoe leuk ze het programma vonden, hoeveel ze ervan hebben geleerd (kinderen), of ze het goed georganiseerd vonden en of het geschikt was voor hun klas (leerkrachten).

De waardering van Smaaklessen is alleen gemeten in de EUS+SL groep door vragen aan de vragenlijsten voor de kinderen $(n=18)$ en leerkrachten $(n=15)$ toe te voegen tijdens de eerste nameting (T1). Onder andere vragen over hoe leuk en interessant ze de lessen en bijbehorende activiteiten vonden zijn hierin meegenomen. Deze vragen zijn gebaseerd op eerder onderzoek over Smaaklessen (51).

\subsubsection{Implementatie van EU-Schoolfruit en Smaaklessen}

De implementatie van EU-Schoolfruit is gemeten in de vragenlijst voor de leerkrachten (aantal vragen $\mathrm{n}=12$ ) in zowel de EUS groep als de EUS+SL groep. In de vragenlijst voor de leerkrachten zijn tijdens de eerste nameting ( $\mathrm{T} 1$ ) vragen opgenomen over de verdeling van het fruit en de eetmomenten in de klas. De implementatie van Smaaklessen (aantal vragen $n=25$ ) is alleen gemeten binnen de EUS+SL groep. Vragen over de uitvoering van de lessen en activiteiten die de leerkrachten hebben uitgevoerd zijn meegenomen. De implementatie is alleen tijdens de eerste nameting gemeten (T1) aangezien dit het moment was wanneer beide programma's actief ingezet werden.

Om de associatie tussen de implementatie en het kennisniveau te onderzoeken zijn de resultaten ingedeeld in twee categorieën, namelijk 'lage implementatie' en 'hoge implementatie'. De categorie 'lage implementatie' houdt in dat de leerkrachten twee of minder lessen hebben uitgevoerd en 'hoge implementatie' betekent dat de leerkrachten drie tot vijf lessen hebben uitgevoerd. 


\subsubsection{Voedingsbeleid}

In de vragenlijst voor leerkrachten zijn tijdens de eerste nameting (T1) en de tweede nameting (T2) vragen over voedingsbeleid opgenomen. Aspecten als het soort beleid, de inhoud en de naleving van het beleid zijn gemeten. Resultaten van T1 zijn gebruikt om het voedingsbeleid van schooljaar 2018/2019 te meten en de uitkomsten van T2 geven een overzicht van voedingsbeleid in schooljaar 2019/2020. De uitkomstmaat voedingsbeleid is voor de analyses opgesplitst in drie categorieën: 1) geen voedingsbeleid, 2) pauzehap, 3) pauzehap + een ander groente- en fruit beleid. De optie 'geen voedingsbeleid' houdt in dat de school op dat moment geen actief pauzehap beleid implementeerde. De optie 'pauzehap' houdt in dat de kinderen elke dag in de ochtendpauze een gezonde snack eten (zoals fruit, groente of een volkoren boterham). De optie 'pauzehap + een ander groente- en fruit beleid' houdt in dat de school naast de gezonde pauzehap nog een ander beleid voert op een ander voedingsgebied, zoals 'gezonde traktatie' en/of 'gezonde lunch'. Gezonde traktatie houdt in dat de school de ouders vraagt om traktaties klein te houden en niet te calorierijk te maken (met bijvoorbeeld groente en/of fruit), of een klein cadeautje mee te geven in plaats van iets eetbaars. Gezonde lunch betekent dat de school de ouders vraagt om geen koek, snoep of chips in de broodtrommel te doen. Geschikte voorbeelden zijn onder andere: volkorenbrood, roggebrood of mueslibol met groente en fruit (52).

\subsubsection{Gezondheidsbevorderend gedrag van ouders}

In de vragenlijst voor de kinderen is gezondheidsbevorderend gedrag (GBG) van ouders gemeten, gebaseerd op eerder ontwikkelde vragenlijsten $(53,54)$. De vragen afkomstig uit de vragenlijst van Poelman et al. (53) zijn aangepast en geschikt gemaakt voor kinderen, aangezien de originele vragenlijst gericht was op de voedselvaardigheden van volwassenen. Deze aanpassing leidde tot een verschuiving van het meten van voedselvaardigheden (de oorspronkelijke uitkomstmaat), naar het GBG van ouders. De vragen meten twee aspecten ( $n=$ aantal vragen), namelijk voedselvoorziening $(n=3)$ (bv. wat krijgen de kinderen mee naar school) en het stimuleren van gezond eetgedrag in de thuisomgeving $(n=2)$ (bv. wordt er thuis over gezond eten gepraat). De resultaten zijn vervolgens ingedeeld in twee categorieën, namelijk 'laag GBG' en 'hoog GBG'. De categorie 'laag GBG' houdt in dat GBG op een laag niveau is ingezet door de ouders (bv. het vaak meegeven van snoep/koek) en 'hoog GBG' betekent dat GBG op een hoog niveau gemeten is bij de ouders (bv. het vaak meegeven van groente en fruit) (zie Tabel 1 ). 
Tabel 1 Overzicht van de vragenlijsten voor kinderen en leerkrachten met aantal vragen, voorbeeldvragen en antwoordmogelijkheden per uitkomstmaat.

\begin{tabular}{|c|c|c|c|c|}
\hline \multirow[t]{2}{*}{ Uitkomstmaat } & \multicolumn{2}{|c|}{ Aantal vragen } & \multirow{2}{*}{$\begin{array}{l}\text { Voorbeeldvraag } \\
\text { (L=leerkrachten, } \\
\text { K=kinderen) }\end{array}$} & \multirow{2}{*}{$\begin{array}{l}\text { Antwoordmogelijkheden } \\
\text { (L=leerkrachten, } \\
\text { K=kinderen) }\end{array}$} \\
\hline & Kinderen & Leerkrachten & & \\
\hline \multicolumn{5}{|l|}{ Effect uitkomsten } \\
\hline Kennis over voeding & 24 & - & $\begin{array}{l}\text { 'In volkorenbrood } \\
\text { zitten... (omcirkel het } \\
\text { goede antwoord)' }\end{array}$ & $\begin{array}{l}4 \text { opties: 1) 'minder vitamines en } \\
\text { mineralen dan in wit brood' } \\
\text { 2) 'evenveel vitamines en } \\
\text { minderalen als in wit brood' } \\
\text { 3) 'meer vitamines en minderalen } \\
\text { dan in wit brood' 4) 'ik weet het } \\
\text { niet' }^{\text {ik w }}\end{array}$ \\
\hline Groente- en fruitconsumptie & 15 & - & $\begin{array}{l}\text { 'Wat voor groente of } \\
\text { fruit, en hoeveel heb je } \\
\text { daarvan gegeten?' }\end{array}$ & $\begin{array}{l}\text { Zie Figuur } 5 \text { voor } \\
\text { antwoordcategorieën }\end{array}$ \\
\hline \multicolumn{5}{|l|}{ Proces uitkomsten } \\
\hline Waardering EU-Schoolfruit & 18 & 15 & $\begin{array}{l}\text { L: 'Ik wil EU-Schoolfruit } \\
\text { nog wel eens inzetten' } \\
\text { K: 'Hoe leuk vond je } \\
\text { EU-Schoolfruit?' }\end{array}$ & $\begin{array}{l}\text { L: } 1-5 \text { schaal, van 'helemaal mee } \\
\text { oneens }=1 \text { ' tot 'helemaal mee eens } \\
=5^{\prime} \\
\mathrm{K}: 1-10 \text { schaal, van 'helemaal niet } \\
\text { leuk }=1 \text { ' tot 'heel erg leuk }=10 \text { ' }\end{array}$ \\
\hline Waardering Smaaklessen & 18 & 15 & $\begin{array}{l}\text { L: 'Het aangereikte } \\
\text { materiaal vind ik } \\
\text { bruikbaar voor mijn } \\
\text { klas' } \\
\text { K: 'Hoe leuk vond je de } \\
\text { activiteit proefjes } \\
\text { doen?' }\end{array}$ & $\begin{array}{l}\text { L: } 1-5 \text { schaal, van 'helemaal mee } \\
\text { oneens }=1 \text { ' tot 'helemaal mee eens } \\
=5 \text { ' } \\
\mathrm{K}: 1-6 \text { schaal, van 'helemaal niet } \\
\text { leuk }=1 \text { ' tot 'deze les heb ik niet } \\
\text { gehad }=6 \text { ' }\end{array}$ \\
\hline $\begin{array}{l}\text { Implementatie EU- } \\
\text { Schoolfruit }\end{array}$ & - & 8 & $\begin{array}{l}\text { 'Hoe biedt u groente en } \\
\text { fruit aan, aan de } \\
\text { kinderen?' }\end{array}$ & $\begin{array}{l}3 \text { opties: } 1 \text { ) 'het ligt in een schaal } \\
\text { zichtbaar in de klas' 2) 'Het ligt in } \\
\text { de doos waarin het geleverd is' } \\
\text { 3) 'anders, namelijk...' }\end{array}$ \\
\hline Implementatie Smaaklessen & - & 10 & $\begin{array}{l}\text { 'Tijdens de } \\
\text { lessen/activiteiten heb } \\
\text { ik de doelen van de les } \\
\text { aan de kinderen verteld' }\end{array}$ & $\begin{array}{l}\text { 1-5 schaal, van 'helemaal mee } \\
\text { oneens }=1 \text { ' tot 'helemaal mee eens } \\
=5^{\prime}\end{array}$ \\
\hline \multicolumn{5}{|l|}{ Context factoren } \\
\hline Voedingsbeleid & - & 9 & $\begin{array}{l}\text { 'Indien uw school geen } \\
\text { actief voedingsbeleid } \\
\text { voert, wat is de reden } \\
\text { hiervoor?' }\end{array}$ & Open vraag \\
\hline $\begin{array}{l}\text { Gezondheidsbevorderend } \\
\text { gedrag van ouders }\end{array}$ & 5 & - & $\begin{array}{l}\text { 'Wordt er bij jou thuis } \\
\text { over gezond eten } \\
\text { gepraat?' }\end{array}$ & 3 opties: 1) 'ja', 2) 'soms', 3) 'nee' \\
\hline
\end{tabular}




\subsection{Statistische analyses}

Ten eerste zijn de demografische kenmerken van de leerlingen, scholen en leerkrachten geanalyseerd door gemiddeldes en standaard deviaties te berekenen van de continue variabelen en frequenties van categorische variabelen per studie groep (EUS, EUS+SL en controle).

Om veranderingen in GF consumptie en kennis te evalueren op de korte en lange termijn werden uitkomsten bij start van de interventie (T0) vergeleken met het einde van de interventie (T1) en zes maanden na het einde van de interventie (T2). Hiervoor werden multilevel modellen gebruikt met drie niveaus: school, klas en individu. Multilevel modellen werden gebruikt om te corrigeren voor het feit dat data kan clusteren binnen scholen of binnen klassen. De geschatte regressiecoëfficiënten reflecteren het verschil in verandering van GF consumptie/kennis gedurende de tijd tussen de controlegroep en de interventiegroepen. Om te evalueren of voedingsbeleid op school (T1) en gezondheidsbevorderend gedrag (GBG) van ouders (TO) invloed hadden op het effect van de interventies zijn deze variabelen als effect modifier meegenomen in het model. Daarnaast werd de associatie tussen het GBG van de ouders en GF consumptie/kennis onafhankelijk van de interventie geanalyseerd op T0, waarbij het voedingsbeleid is meegenomen als confounder.

Gemiddeldes van de waardering van EU-Schoolfruit en Smaaklessen zijn berekend voor kinderen en leerkrachten. Daarnaast zijn verschillen in waardering en implementatie van beide programma's tussen de EUS- en de EUS+SL groep vergeleken met een onafhankelijke t-toets. Het effect van de implementatie van Smaaklessen op het kennisniveau van de kinderen is gemeten met behulp van een multilevel model, waarbij de associatie tussen het aantal gegeven lessen en verandering in kennis van kinderen (korte en lange termijn) is onderzocht.

Voor alle analyses werd een p-waarde van minder dan 0.05 beschouwd als significant. Alle analyses zijn gecorrigeerd voor leeftijd en geslacht, om rekening te houden met mogelijke confounding. De lineariteit, normaliteit en homogeniteit (assumpties) van de residuen zijn gecontroleerd, waarbij lichte afwijkingen van normaliteit en homogeniteit zijn waargenomen. De statistische analyses zijn uitgevoerd met software R versie 3.6.1 en SPSS Statistics versie 23.0. 


\section{Resultaten}

\subsection{Kenmerken van de studiepopulatie}

In Tabel 2 zijn de kenmerken van de kinderen, leerkrachten en scholen weergegeven die deel hebben genomen aan de effectmeting. Deze tabel laat zien dat de gemiddelde leeftijd, het percentage meisjes en jongens en het percentage leerlingen in groep 6 en 7 vergelijkbaar is in de drie groepen (EUS+SL-, EUS- en controlegroep) tijdens de eerste meting (TO). Kenmerken van de leerkrachten (tijdens T1) laten zien dat er meer vrouwen deelnamen dan mannen (80.3\% versus $19.7 \%$ ). De gemiddelde ervaring als leerkracht was 17 jaar en de gemiddelde leeftijd was 41 jaar. Daarnaast zijn van de scholen de waardes van de sociaal-economische positie (SEP), het voedingsbeleid (gemeten tijdens het tweede meetmoment T1), grondslag, grootte en locatie weergeven. Hierbij is te zien dat de controlescholen een hogere sociaal-economische positie hadden dan de interventiescholen. Daarnaast hadden meer interventiescholen een voedingsbeleid in vergelijking met scholen uit de controlegroep. De EUS+SL groep had in vergelijking met de EUS- en controlegroep een hoog percentage scholen met openbare grondslag. De EUS groep bevatte een hoog percentage kleine scholen gelegen in dorpen.

Tabel 2 Kenmerken van de deelnemende kinderen, leerkrachten en scholen in de effectmeting.

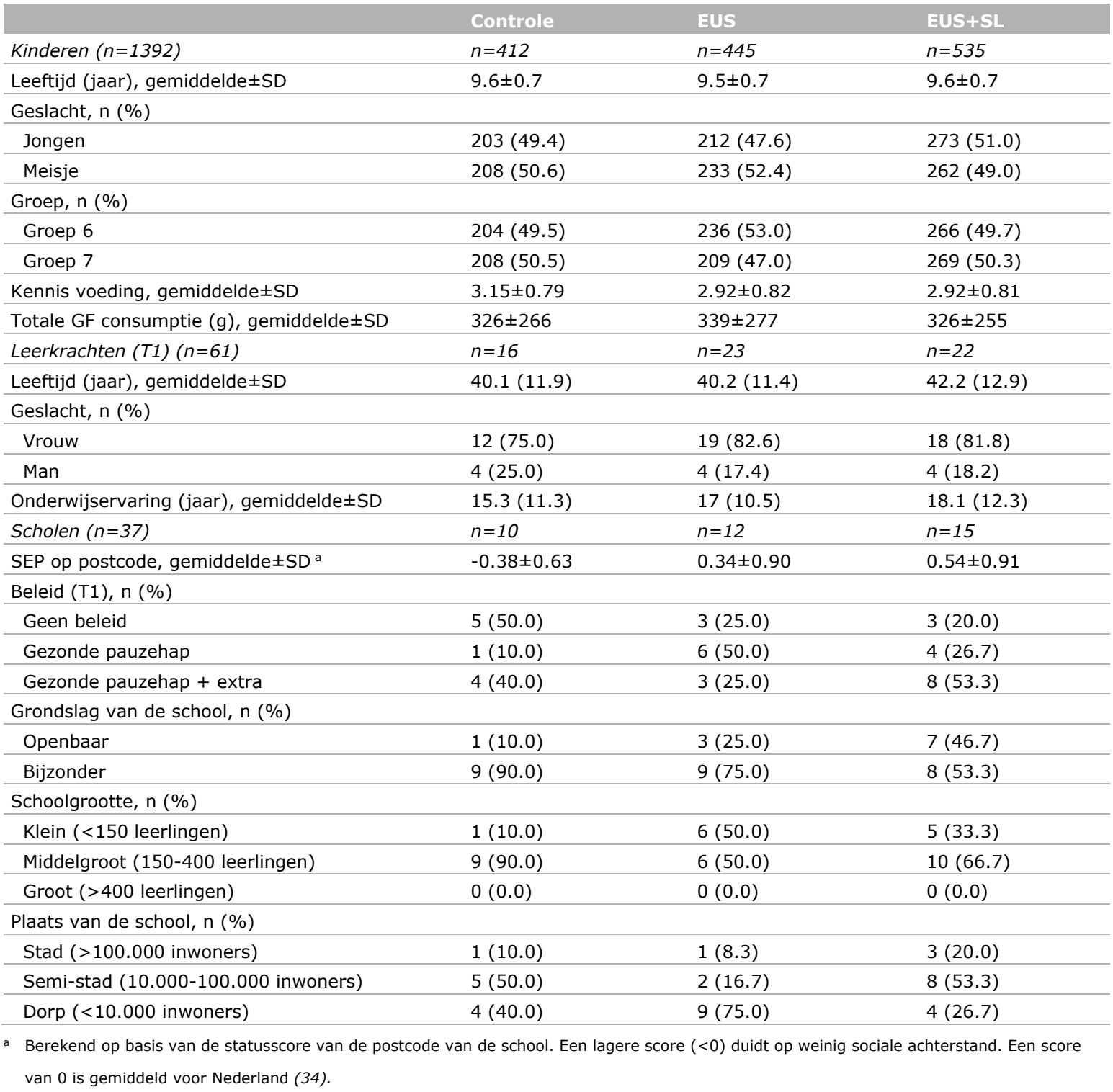




\subsection{Effect op groente- en fruitconsumptie}

Er is geen verschil in groente- en fruitconsumptie bij kinderen waargenomen tussen de interventiegroepen en de controlegroep (zie Figuur 6). Resultaten van de analyses zijn te vinden in Bijlage 2.

Verschil GF consumptie T0 -T1 en T0 -T2

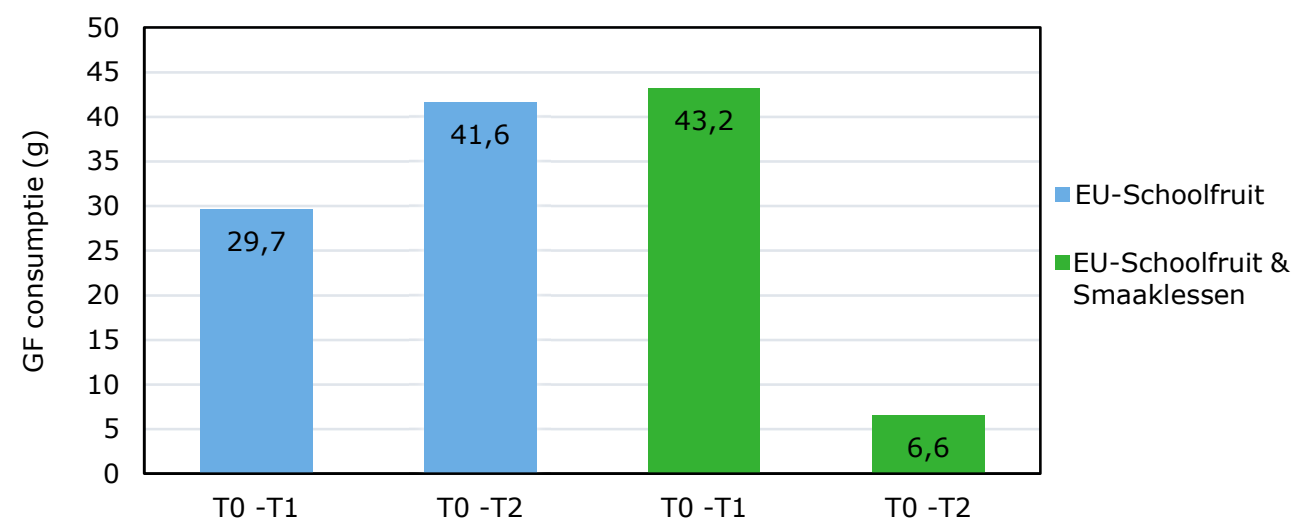

Figuur 6 Verschil in GF consumptie bij kinderen in vergelijking met controlegroep TO-T1 en TO-T2.

\subsection{Effect op kennis over gezonde voeding}

Op scholen waar EU-Schoolfruit gecombineerd werd met Smaaklessen was een significante toename in kennis over voeding van kinderen te zien op zowel korte- als lange termijn (zie Figuur 7). De verandering in kennis was significant hoger wanneer drie tot vijf lessen werden uitgevoerd, dan wanneer twee of minder lessen werden uitgevoerd. Dit gold zowel op de korte termijn $(\beta=0.18$; $95 \% \mathrm{CI}: 0.03,0.33)$ als op de lange termijn ( $\beta=0.23,95 \% \mathrm{CI}: 0.08,0.38)$. EU-Schoolfruit alleen had geen significant effect op de kennis over voeding van kinderen. Resultaten van de analyses zijn te vinden in Bijlage 3.

Verschil Kennis T0 -T1 en T0 -T2

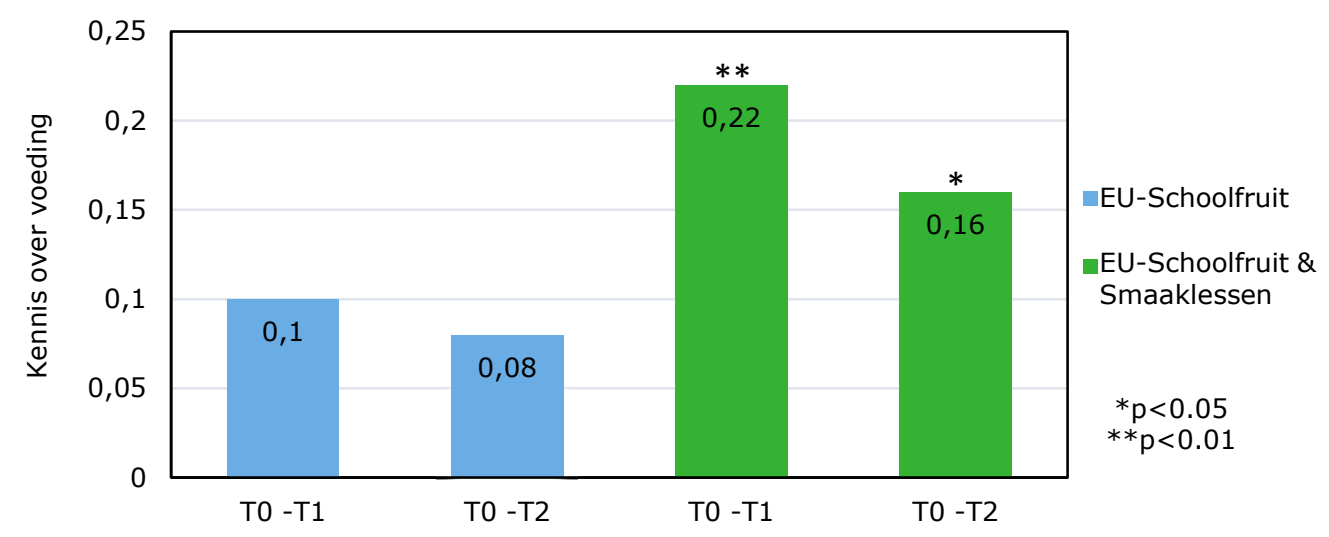

Figuur $7 \quad$ Verschil in kennis over voeding bij kinderen in vergelijking met controlegroep TO-T1 en TO-T2. 


\subsection{Waardering EU-Schoolfruit en Smaaklessen}

\subsubsection{Waardering EU-Schoolfruit en Smaaklessen van kinderen}

Beide programma's waren positief beoordeeld door de kinderen uit de interventiegroepen. EU-schoolfruit was significant hoger gewaardeerd door kinderen die aan EU-Schoolfruit en Smaaklessen meededen (gemiddelde score 3.8, op schaal 1-5) dan door kinderen die alleen aan EU-Schoolfruit meededen (gemiddelde score 3.6). Verder werden kleine verschillen in waardering tussen de interventiegroepen gerapporteerd, waarbij kinderen die meededen aan beide programma's het EU-Schoolfruitprogramma iets interessanter, lekkerder, maar ook minder gemakkelijk vonden dan kinderen die alleen meededen aan EU-Schoolfruit (zie Figuur 8).

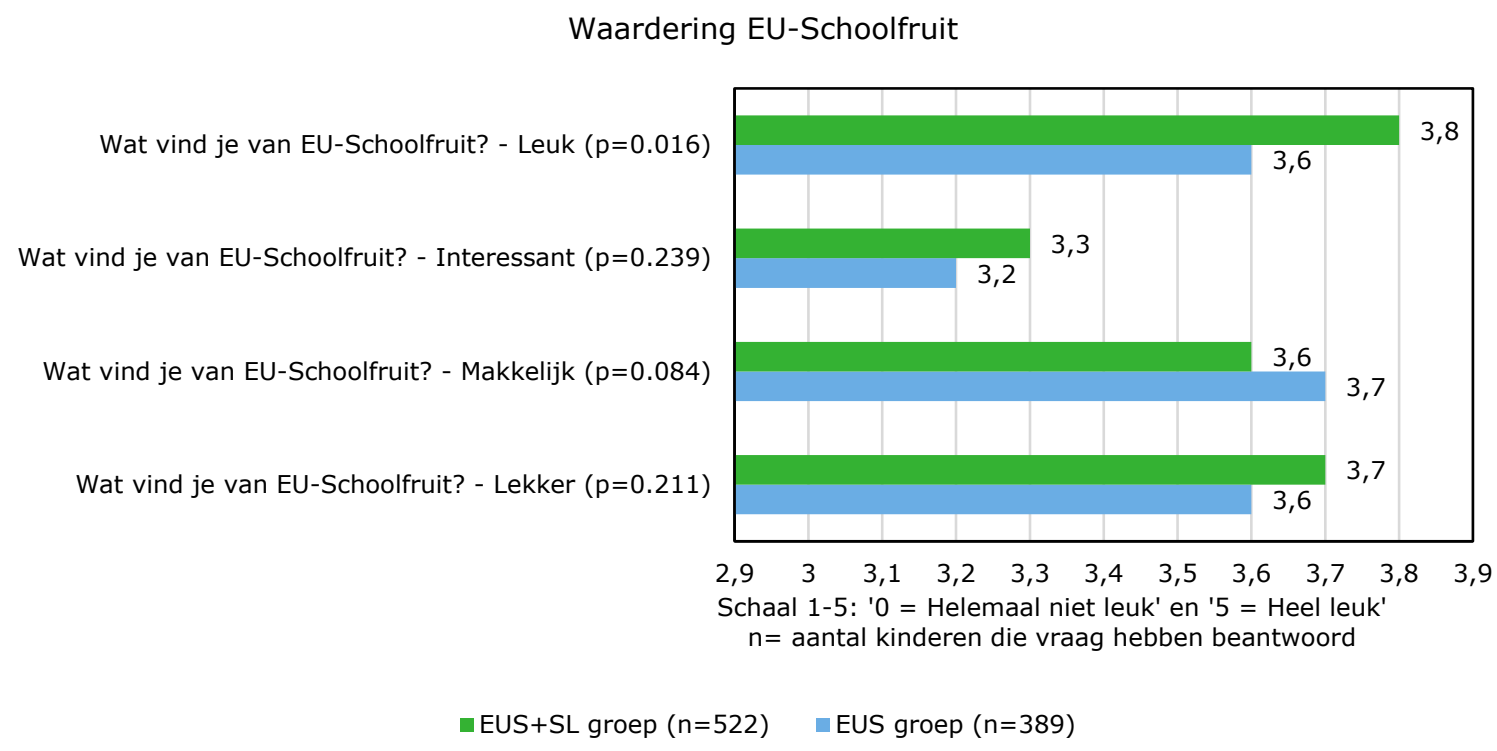

Figuur 8 Waardering van EU-Schoolfruit van kinderen.

De waardering van Smaaklessen werd onder de kinderen in de EUS+SL groep gemeten door te vragen in hoeverre ze de lessen en de activiteiten leuk vonden. De lessen 1-4 zijn gemiddeld met een 3.8 beoordeeld en les 5 over het bereiden van een gezonde snack is beoordeel met een 3.9 (zie Figuur 9). Thuis opdrachten maken werd het minst leuk gevonden (2.5) en proefjes doen werd als leukst beoordeeld (4.3). 
Les 1 - Smaakmakers $(n=208)$

Les 2 - Het komkommerdebat $(n=220)$ Les 3 - Waar komt ons eten vandaan? $(n=154)$ Les 4 - Lekker uit de Schijf van Vijf $(n=148)$ Les 5 - Restaurant in de klas $(n=16)$ Gerechten klaarmaken $(n=305)$ Thuis recepten opzoeken $(n=298)$ Thuis opdrachten maken $(n=297)$ Leren over smaak en eten $(n=310)$ Informatie opzoeken $(n=305)$ Debatteren over eten $(n=310)$ Producten proeven $(n=312)$ Proefjes doen $(n=313)$ Met elkaar praten over eten $(n=317)$

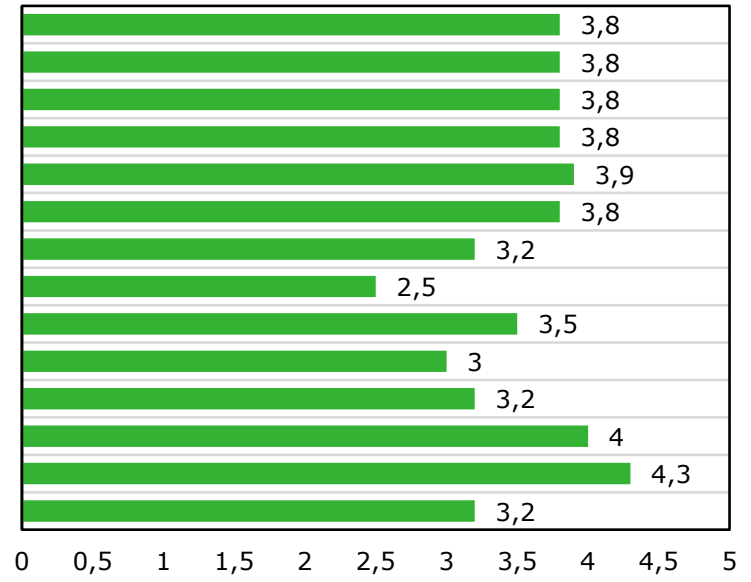

Schaal 1-5: ' $0=$ Helemaal niet leuk' en ' $5=$ Heel leuk' $\mathrm{n}=$ aantal kinderen die vraag hebben beantwoord

Figuur 9 Waardering van lessen en activiteiten van Smaaklessen van kinderen.

\subsubsection{Waardering EU-Schoolfruit en Smaaklessen van leerkrachten}

Van alle 59 leerkrachten die de vragenlijst tijdens de eerste nameting (T1) hebben ingevuld hebben 44 leerkrachten EU-Schoolfruit ingezet (75\%) en van deze leerkrachten hebben 21 ook Smaaklessen ingezet ( $36 \%$ van totaal). De overige 15 leerkrachten (26\%) hebben geen EU-Schoolfruit en Smaaklessen ingezet (controlegroep) (zie Tabel 3). Zowel EU-Schoolfruit als Smaaklessen zijn positief beoordeeld door de leerkrachten. Er werden enkele verschillen in waardering tussen de interventiegroepen gerapporteerd. EU-Schoolfruit kostte meer tijd dan van tevoren gedacht, maar minder voorbereidingstijd dan Smaaklessen. Daarnaast werd EU-Schoolfruit als bruikbaarder voor in de klas ervaren en meer van toegevoegde waarde dan Smaaklessen. Ook gaven de leerkrachten aan dat EU-Schoolfruit meer effect heeft op de kinderen dan Smaaklessen (zie Tabel 3).

Tabel 3 Waardering EU-Schoolfruit en Smaaklessen van leerkrachten (T1).

\begin{tabular}{|c|c|c|}
\hline $\begin{array}{l}\text { Vragen in leerkrachten vragenlijst (schaal } 1-5, ' 1=\text { Helemaal mee } \\
\text { oneens' en ' } 5=\text { Helemaal mee eens') }\end{array}$ & $\begin{array}{l}\text { EU-Schoolfruit } \\
\text { Gemiddelde (SD) } \\
(n=23)\end{array}$ & $\begin{array}{l}\text { Smaaklessen } \\
\text { Gemiddelde (SD) } \\
(n=20)\end{array}$ \\
\hline $\begin{array}{l}\text { Het programma heeft mij meer tijd gekost dan ik van te voren had } \\
\text { verwacht }\end{array}$ & $3.6(0.8)$ & $2.6(0.7)$ \\
\hline $\begin{array}{l}\text { De voorbereiding van het programma heeft mij meer tijd gekost dan ik } \\
\text { van te voren had verwacht }\end{array}$ & $3.7(0.8)$ & $4.0(0.4)$ \\
\hline Ik vond het programma leuk om in te zetten & $4.1(0.3)$ & $4.1(0.4)$ \\
\hline De kinderen vonden het programma leuk & $4.0(0.3)$ & $4.0(0.3)$ \\
\hline Het programma was goed georganiseerd & $3.9(0.7)$ & $3.9(0.6)$ \\
\hline Ik vind het programma van toegevoegde waarde & $4.2(0.4)$ & $4.0(0.3)$ \\
\hline Ik had voldoende kennis om het programma uit te voeren & $4.3(0.4)$ & $4.1(0.4)$ \\
\hline Ik had voldoende vaardigheden om het programma uit te voeren & $4.0(0.4)$ & $4.2(0.3)$ \\
\hline Ik wil het programma nog wel eens inzetten & $4.4(0.5)$ & $4.1(0.3)$ \\
\hline $\begin{array}{l}\text { Ik wil aan de slag blijven gaan met het aanbieden van fruit en groente/het } \\
\text { geven van lessen aan de kinderen }\end{array}$ & $4.3(0.6)$ & $4.1(0.4)$ \\
\hline Het programma heeft effect gehad op de kinderen & $4.1(0.4)$ & $3.7(0.5)$ \\
\hline
\end{tabular}




\subsection{Implementatie EU-Schoolfruit en Smaaklessen}

\subsubsection{Implementatie EU-Schoolfruit}

De groente en het fruit van EU-Schoolfruit werd meestal aangeboden in een fruitschaal tijdens de ochtendpauze, waarbij de kinderen zelf kozen welk groente- en/of fruitsoort ze aten. Leerkrachten besteedden ongeveer 15 minuten per dag aan EU-Schoolfruit. De meeste leerkrachten maakten de groente en het fruit zelf klaar en namen zelf ook vaak fruit en/of groente tijdens het groente- en fruitmoment. Ruim $25 \%$ van de leerkrachten gaf aan belemmeringen te ervaren met het inzetten van EU-Schoolfruit. De meestgenoemde obstakels waren gerelateerd aan tijd en de kwaliteit van de verstrekte groente en fruit van EU-Schoolfruit. Ondanks deze belemmeringen gaven vrijwel alle leerkrachten (96\%) aan volgend jaar weer EU-Schoolfruit in te willen zetten (zie Tabel 4).

Tabel 4 Implementatie van EU-Schoolfruit en Smaaklessen (T1).

\begin{tabular}{|c|c|c|c|c|}
\hline \multirow[t]{2}{*}{ Implementatie } & \multicolumn{2}{|c|}{ EUS groep $(N=23)$} & \multicolumn{2}{|c|}{ EUS+SL groep $(N=22)$} \\
\hline & $\mathbf{N}$ & Gemiddelde (SD)/ \% & $\mathbf{N}$ & Gemiddelde (SD)/ \% \\
\hline \multicolumn{5}{|l|}{ Het aanbieden van $G F^{*}$} \\
\hline In de doos van levering & 1 & 4.5 & 7 & 31.2 \\
\hline Anders.. & 8 & 36.4 & 5 & 22.7 \\
\hline Tijdens de ochtendpauze & 22 & 100 & 20 & 90.9 \\
\hline Tijdens de lunchpauze & 4 & 18.2 & 9 & 40.9 \\
\hline Tijdens de middagpauze & 0 & 0 & 1 & 4.5 \\
\hline Anders.. & 2 & 9.1 & 2 & 9.1 \\
\hline Leerkracht verdeelt GF & 10 & 45.5 & 5 & 22.7 \\
\hline Anders.. & 4 & 18.2 & 3 & 13.6 \\
\hline \multicolumn{5}{|l|}{ Implementatie EU-Schoolfruit* } \\
\hline Kinderen maken GF klaar & 5 & 22.7 & 6 & 27.3 \\
\hline Leerkrachten maken GF klaar & 11 & 50 & 11 & 50 \\
\hline GF is klaar met levering & 0 & 0 & 2 & 9.1 \\
\hline Anders.. & 8 & 36.4 & 7 & 31.2 \\
\hline \multicolumn{5}{|l|}{ Implementatie EU-Schoolfruit* } \\
\hline Kinderen moeten GF proeven & 7 & 31.8 & 7 & 31.2 \\
\hline$>15$ minuten per dag & 1 & 4.3 & 0 & 0 \\
\hline \multicolumn{5}{|l|}{ Leerkracht neemt zelf ook GF } \\
\hline Altijd & 15 & 68.2 & 18 & 82 \\
\hline Soms & 7 & 31.8 & 3 & 14 \\
\hline Nooit & 0 & 0 & 1 & 4.0 \\
\hline \multicolumn{5}{|l|}{ Implementatie Smaaklessen } \\
\hline Gedurende het hele schooljaar & & & 10 & 47.6 \\
\hline Tijdens een projectweek & & & 6 & 28.6 \\
\hline Tijdens een vak & & & 1 & 4.8 \\
\hline Anders.. & & & 4 & 19.0 \\
\hline \multicolumn{5}{|l|}{ Implementatie Smaaklessen } \\
\hline Door mijzelf & & & 11 & 61,1 \\
\hline Met anderen & & & 7 & 38.9 \\
\hline Volgend jaar weer EUS - 'Ja' & 22 & 96 & 20 & 91 \\
\hline Volgend jaar weer SL- 'Ja' & & & 20 & 91 \\
\hline
\end{tabular}

* Sommige leerkrachten hebben bij deze vraag meerdere antwoorden gegeven. 


\subsubsection{Implementatie Smaaklessen}

De leerkrachten uit de EUS+SL groep werden verzocht om vijf Smaaklessen in de periode van EU-Schoolfruit in te zetten bij hun groep 6 en/of 7. Leerkrachten hadden gemiddeld 2.9 (SD=0.9) lessen ingezet met een gemiddelde duur van 53 minuten. De eerste twee Smaaklessen over zintuigen en productiewijze zijn het vaakst ingezet. Smaakles 5, een les over het bereiden van een gezonde snack, is het minst vaak ingezet. In totaal bestonden de vijf lessen uit 28 verschillende activiteiten: 17 basis les elementen, 6 online elementen, 4 toegevoegde elementen en een afsluitende toets. Leerkrachten hadden gemiddeld 9.2 activiteiten $(S D=3.6)$ uitgevoerd, waarvan vooral de basiselementen zijn ingezet (zie Figuur 10). De eindtoets is door geen enkele leerkracht ingezet. Meer dan de helft van de leerkrachten heeft Smaaklessen zelf ingezet en de meeste leerkrachten kozen ervoor Smaaklessen in te zetten door het jaar heen. De belemmeringen die het meest genoemd werden hadden te maken met de voorbereidingstijd en de inzet van de lessen binnen het schoolcurriculum.

Aantal activiteiten Smaaklessen

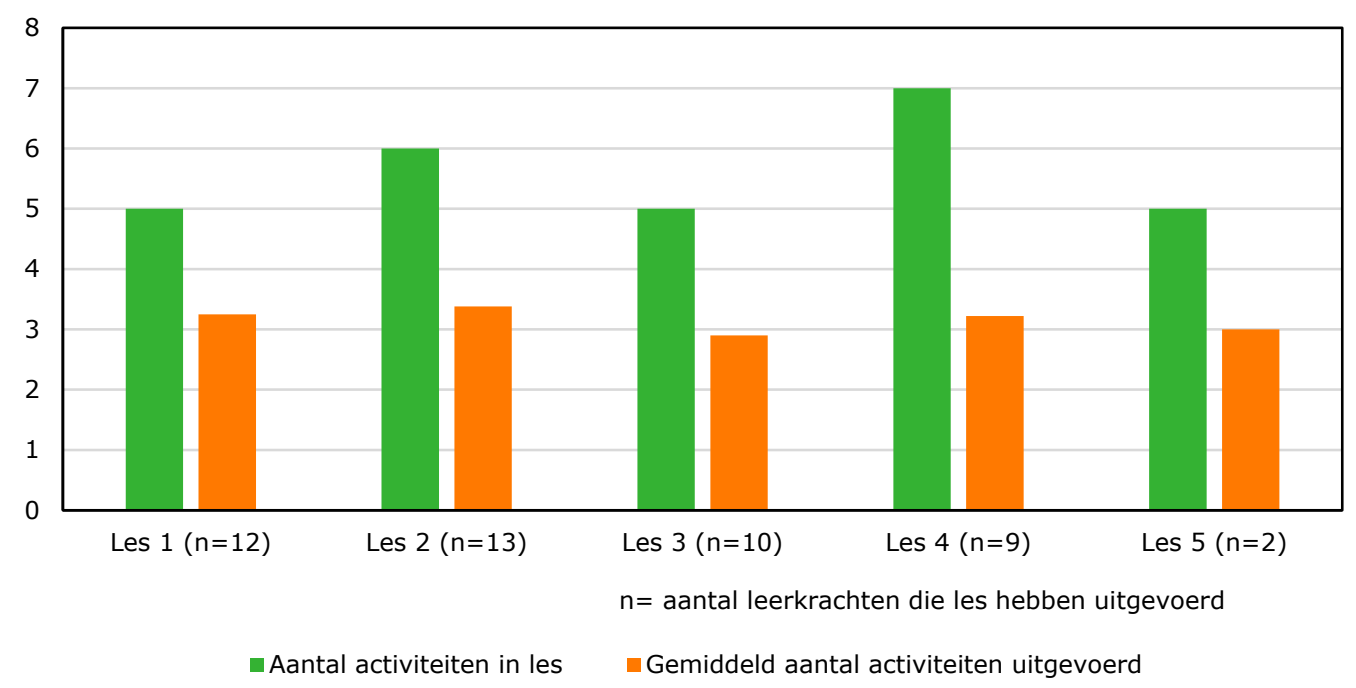

Figuur 10 Aantal activiteiten per les en gemiddeld aantal uitgevoerde activiteiten per les. 


\subsection{Invloed van voedingsbeleid}

Figuur 11 en 12 laten de veranderingen in GF consumptie in de loop van de tijd zien per categorie voedingsbeleid, waarbij de beleidscategorieën zijn gebaseerd op bevindingen van de tweede meting (T1). Verschillen in GF consumptie tussen de metingen waren het grootst in scholen zonder voedingsbeleid. De resultaten laten zien dat de GF consumptie van de EUS groep op scholen zonder beleid significant positief veranderde ten opzichte van de controlegroep (zie Figuur 11). Deze positieve verandering was zowel te zien op de korte termijn (T1) als op de lange termijn (T2). Bij de EUS+SL groep (zie Figuur 12) is op de korte termijn een vergelijkbare toename in GF consumptie zichtbaar, maar dit is niet significant. Daarnaast is dit effect ook niet zichtbaar op de lange termijn. Ook laten de resultaten zien dat op scholen met voedingsbeleid geen significante verschillen zijn gevonden in de veranderingen in GF consumptie tussen de interventiegroepen en de controlegroep. Resultaten van de analyses zijn te vinden in Bijlage 4. Er werd geen verschil in effect van de programma's op kennis gevonden tussen de verschillende beleidscategorieën. Daarom zijn deze resultaten niet meegenomen in het huidige rapport.

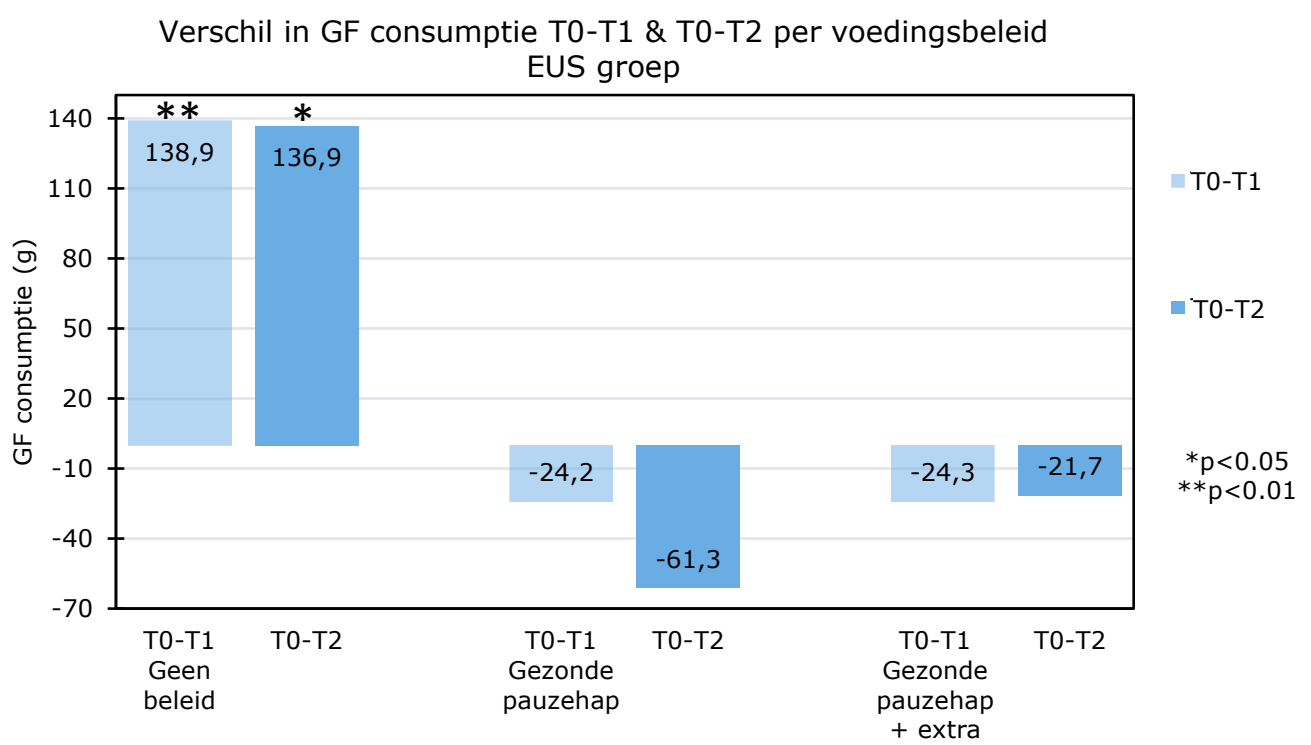

Figuur 11 Verschil in groente- en fruitconsumptie bij kinderen per voedingsbeleid in vergelijking met de controlegroep (TO-T1 \& TO-T2).

Verschil in GF consumptie T0-T1 \& T0-T2 per voedingsbeleid EUS+SL groep

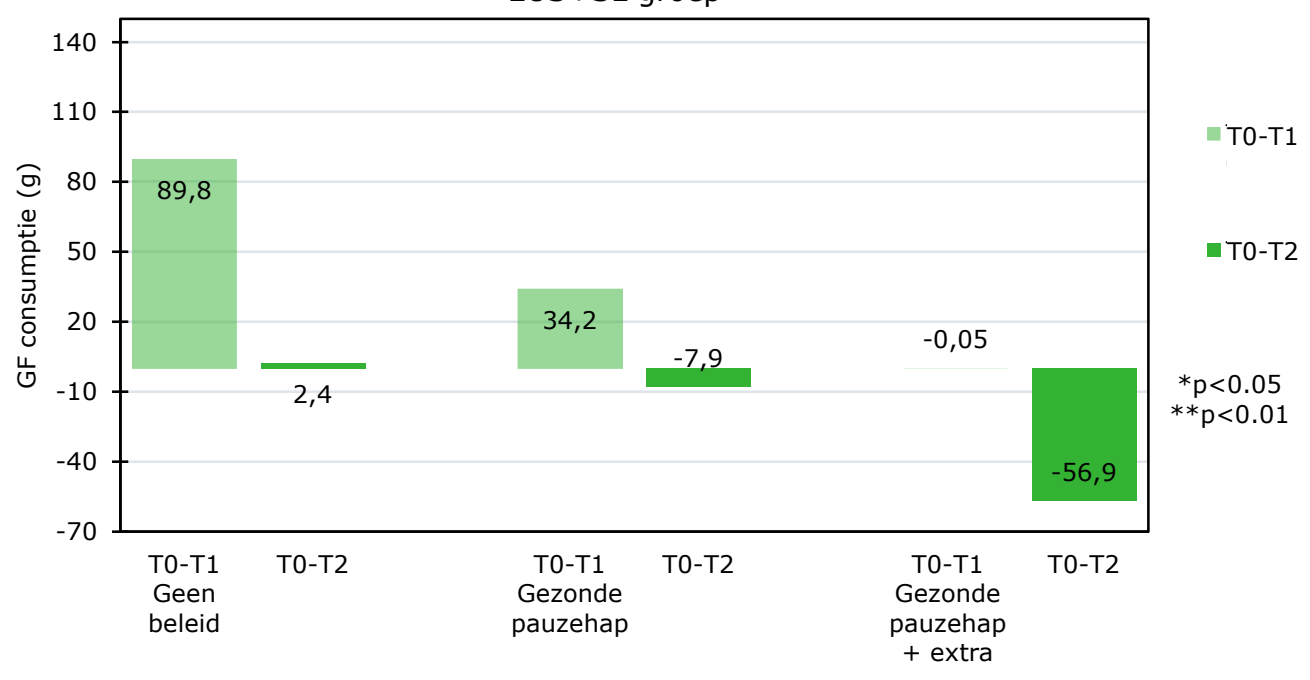

Figuur 12 Verschil in groente- en fruitconsumptie bij kinderen per voedingsbeleid in vergelijking met de controlegroep (TO-T1 \& TO-T2). 


\subsection{Invloed van de ouders}

Het gezondheidsbevorderend gedrag (GBG) van de ouders is ingedeeld in twee categorieën, namelijk meegeefgedrag (meegeven van (1) GF, (2) frisdrank/limonade en (3) snoep/koek) en het stimuleren van gezond eetgedrag in de thuisomgeving (thuis meehelpen met koken (1) en thuis praten over gezond eten (2)). Tabel 5 laat de gemiddelde GF consumptie en kennis van kinderen zien op T0 voor de verschillende categorieën van de vijf vormen van GBG. De resultaten laten zien dat er een associatie is tussen het meegeefgedrag van de ouders en GF consumptie/kennis van het kind. Het vaker meegeven van groente en fruit is significant geassocieerd met een hogere GF consumptie en hogere kennis, terwijl het (elke dag) meegeven van frisdrank/limonade en koek/snoep geassocieerd is met lagere GF consumptie bij kinderen. Het meegeven van koek/snoep is ook geassocieerd met een lagere kennis over gezonde voeding bij kinderen. Daarnaast laten de resultaten zien dat er een associatie is tussen het stimuleren van gezond eten in de thuisomgeving en GF consumptie/kennis. Kinderen die worden betrokken bij het koken rapporteerden een hogere GF consumptie en hogere kennis. Ook het praten over gezond eten was positief geassocieerd met GF consumptie en kennis over gezonde voeding bij kinderen. Figuren 13-17 laten de invloed van het GBG van ouders op het effect van de programma's zien. Bij het opsplitsen van de populatie in kinderen van ouders met laag GBG en kinderen van ouders met hoog GBG werden verschillen gevonden in de effecten van de interventie op GF consumptie. De resultaten laten zien dat er significante veranderingen in GF consumptie waren in de groep met een laag GBG, maar niet in de groep met een hoog GBG. De toename in kennis verschilde niet tussen kinderen van ouders met hoog en laag GBG. Resultaten van de analyses zijn te vinden in Bijlage 5.

Tabel 5 Associatie tussen gezondheidsbevorderend gedrag van de ouders en GF consumptie en kennis van de kinderen, resultaten van de eerste meting (TO).

\begin{tabular}{|c|c|c|c|c|c|c|}
\hline \multirow[b]{2}{*}{ Meegeefgedrag GF } & \multirow{2}{*}{$\begin{array}{c}N \\
1376\end{array}$} & \multicolumn{2}{|c|}{ Totale GF consumptie, g } & \multirow{2}{*}{$\frac{N}{1368}$} & \multicolumn{2}{|c|}{ Kennis, score } \\
\hline & & gemiddelde $[95 \% \mathrm{CI}]$ & $\beta[95 \% \mathrm{CI}]^{\mathrm{b}}$ & & gemiddelde $[95 \% \mathrm{CI}]$ & $\beta[95 \% \mathrm{CI}]^{\mathrm{b}}$ \\
\hline Nooit & 164 & $209[165,254]$ & ref & 162 & $2.76[2.62,2.90]$ & ref \\
\hline 1 keer per week & 137 & $297[249,345]$ & $87.5[28.4,146.6]^{* *}$ & 136 & $2.90[2.75,3.05]$ & $0.14[-0.04,0.32]$ \\
\hline 2-3 keer per week & 177 & $350[307,393]$ & $140.7[84.5,196.9]^{* *}$ & 177 & $2.87[2.73,3.00]$ & $0.11[-0.06,0.28]$ \\
\hline 3-4 keer per week & 268 & $333[297,368]$ & $123.6[72.3,175.0]^{* *}$ & 268 & $3.09[2.97,3.21]$ & $0.33[0.17,0.49]^{* *}$ \\
\hline Elke dag & 630 & $357[331,383]$ & $147.8[101.6,194.1]^{* *}$ & 625 & $3.04[2.95,3.13]$ & $0.28[0.14,0.42]^{* *}$ \\
\hline $\begin{array}{l}\text { Meegeefgedrag } \\
\text { frisdrank/limonade }\end{array}$ & 1361 & & & 1353 & & \\
\hline Nooit & 549 & $339[312,367]$ & ref & 546 & $3.02[2.93,3.11]$ & ref \\
\hline 1 keer per week & 154 & $403[357,449]$ & $63.6[17.0,110.2]^{* *}$ & 153 & $3.01[2.87,3.16]$ & $-0.01[-0.15,0.13]$ \\
\hline 2-3 keer per week & 139 & $376[328,423]$ & $36.5[-12.0,85.0]$ & 137 & $3.01[2.86,3.16]$ & $-0.01[-0.16,0.14]$ \\
\hline 3-4 keer per week & 110 & $352[299,405]$ & $12.5[-41.0,66.0]$ & 109 & $3.01[2.84,3.17]$ & $-0.02[-0.18,0.15]$ \\
\hline Elke dag & 409 & $267[236,298]$ & $-72.5[-107.1,-37.9] * *$ & 408 & $2.89[2.79,2.99]$ & $-0.13[-0.23,-0.02]^{*}$ \\
\hline $\begin{array}{l}\text { Meegeefgedrag } \\
\text { snoep/koek }\end{array}$ & 1367 & & & 1359 & & \\
\hline Nooit & 453 & $333[303,363]$ & ref & 450 & $3.10[3.00,3.19]$ & ref \\
\hline 1 keer per week & 338 & $363[330,396]$ & $30.5[-7.1,68.1]$ & 335 & $2.94[2.83,3.05]$ & $-0.16[-0.27,-0.04]^{* *}$ \\
\hline 2-3 keer per week & 252 & $351[314,388]$ & $18.3[-23.3,59.9]$ & 251 & $2.95[2.84,3.07]$ & $-0.14[-0.27,-0.02]^{*}$ \\
\hline 3-4 keer per week & 146 & $293[246,340]$ & $-40.2[-90.3,9.9]$ & 146 & $2.97[2.82,3.12]$ & $-0.12[-0.28,0.03]$ \\
\hline Elke dag & 178 & $250[207,293]$ & $-82.7[-129.5,-35.9] * *$ & 177 & $2.78[2.64,2.91]$ & $-0.32[-0.46,-0.18]^{* *}$ \\
\hline Helpen met koken & 1368 & & & 1360 & & \\
\hline Nooit & 157 & $259[214,304]$ & ref & 155 & $2.73[2.58,2.87]$ & ref \\
\hline Soms & 745 & $301[277,326]$ & $42.3[-2.8,87.4]$ & 742 & $2.97[2.88,3.05]$ & $0.24[0.10,0.38]^{* *}$ \\
\hline 1 keer per week & 106 & $363[309,417]$ & $103.9[39.6,168.1]^{* *}$ & 106 & $3.14[2.97,3.30]$ & $0.41[0.22,0.61]^{* *}$ \\
\hline 2-3 keer per week & 128 & $415[366,464]$ & $155.8[94.6,217.0]^{* *}$ & 128 & $3.31[3.16,3.46]$ & $0.58[0.40,0.77]^{* *}$ \\
\hline 3-4 keer per week & 78 & $364[303,426]$ & $105.4[34.9,175.8]^{* *}$ & 77 & $3.07[2.88,3.26]$ & $0.34[0.13,0.55]^{* *}$ \\
\hline Elke dag & 154 & $395[349,441]$ & $135.6[77.3,193.9]^{* *}$ & 152 & $2.86[2.71,3.00]$ & $0.13[-0.05,0.31]$ \\
\hline Praten over eten & 1371 & & & 1363 & & \\
\hline Nee & 299 & $272[239,306]$ & ref & 298 & $2.76[2.65,2.87]$ & ref \\
\hline Soms & 744 & $322[298,345]$ & $49.5[14.4,84.6]^{* *}$ & 738 & $2.98[2.90,3.07]$ & $0.22[0.11,0.32]^{* *}$ \\
\hline $\mathrm{Ja}$ & 328 & $392[359,424]$ & $119.5[78.1,160.8]^{* *}$ & 327 & $3.17[3.06,3.28]$ & $0.41[0.28,0.53]^{* *}$ \\
\hline
\end{tabular}


Hoeveel GF mee van huis? Verschil T0-T1 \& T0-T2

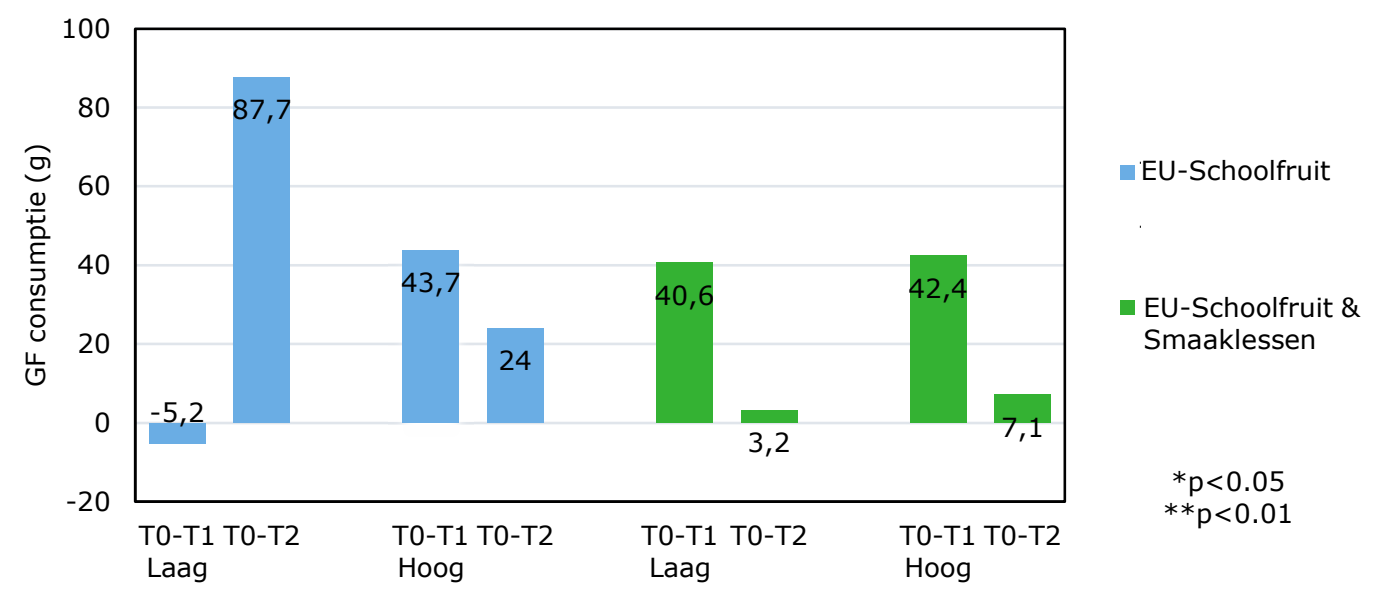

Figuur 13 Verschil in groente- en fruitconsumptie bij kinderen per categorie gezondheidsbevorderend gedrag (GBG) van ouders in vergelijking met de controlegroep (TO-T1 \& TO-T2).

Hoe vaak frisdrank/limonade mee van huis? Verschil T0-T1 \& T0-T2

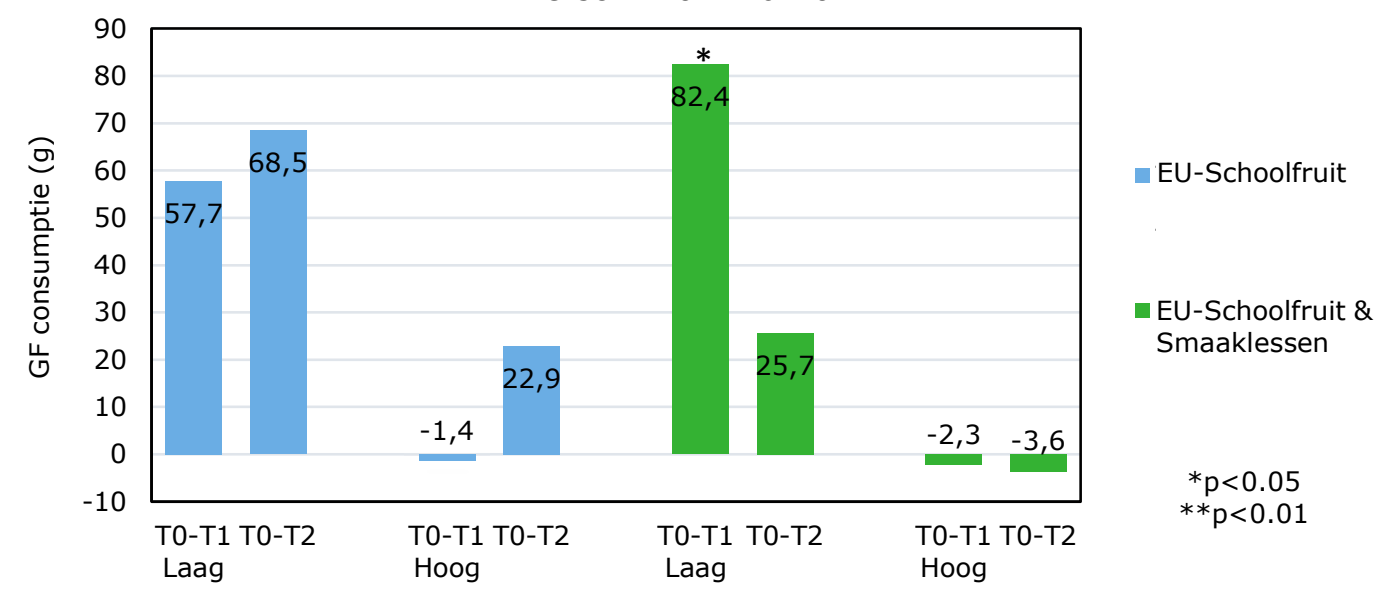

Figuur 14 Verschil in groente- en fruitconsumptie bij kinderen per categorie gezondheidsbevorderend gedrag (GBG) van ouders in vergelijking met de controlegroep (TO-T1 \& TO-T2).

Hoe vaak snoep/koek mee van huis? Verschil T0-T1 \& T0-T2

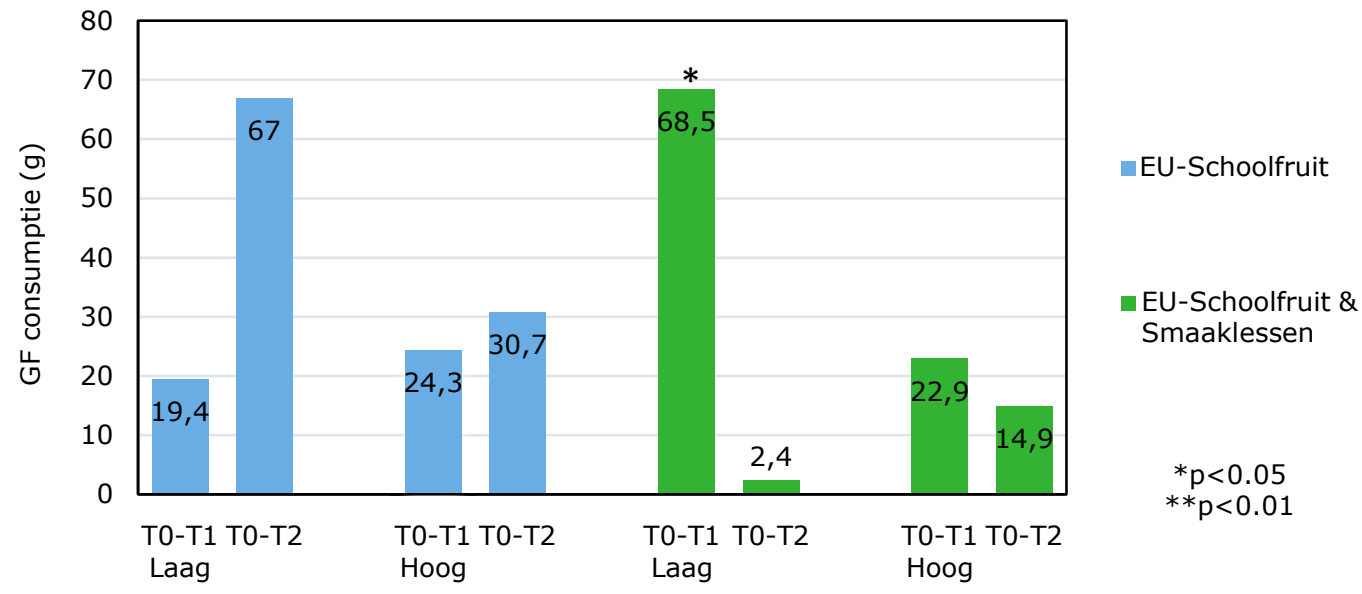

Figuur 15 Verschil in groente- en fruitconsumptie bij kinderen per categorie gezondheidsbevorderend gedrag (GBG) van ouders in vergelijking met de controlegroep (TO-T1 \& TO-T2). 
Hoe vaak help je met koken? Verschil T0-T1 \& T0-T2

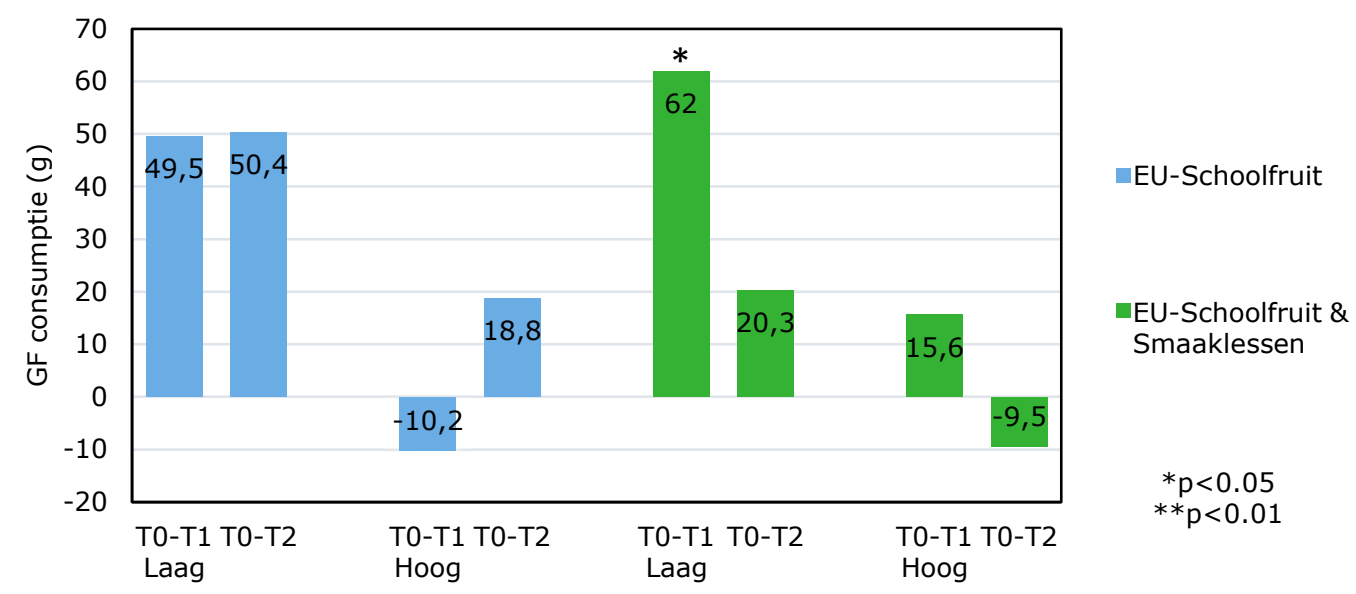

Figuur 16 Verschil in groente- en fruitconsumptie bij kinderen per categorie gezondheidsbevorderend gedrag (GBG) van ouders in vergelijking met de controlegroep (TO-T1 \& TO-T2).

Hoe vaak praat je thuis over gezond eten? Verschil T0-T1 \& T0-T2

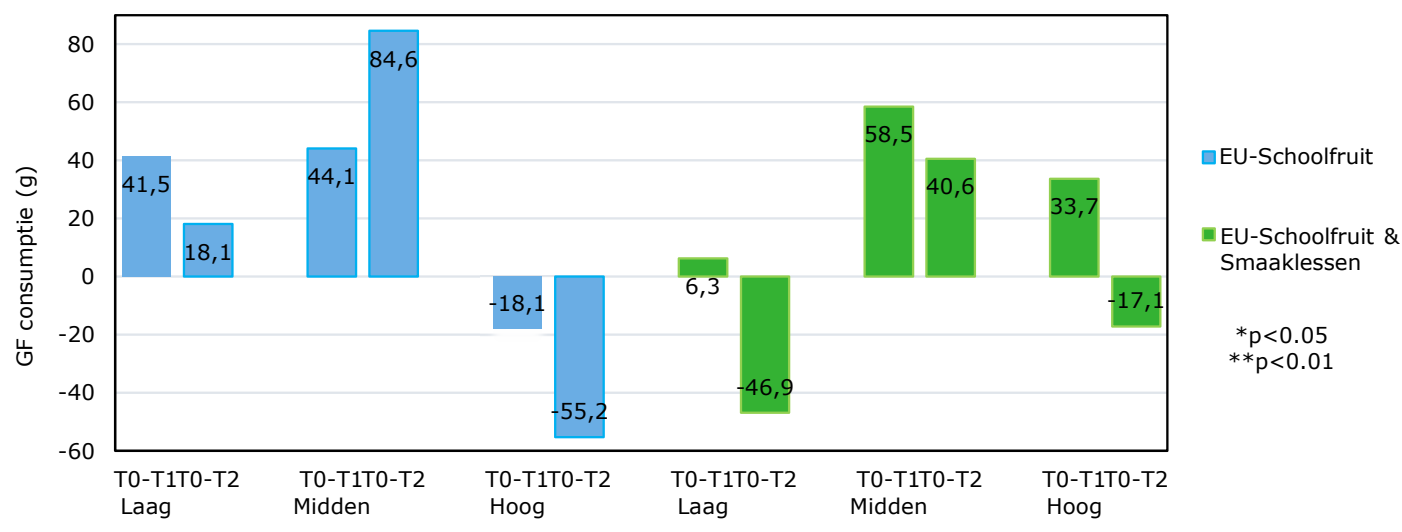

Figuur 17 Verschil in groente- en fruitconsumptie bij kinderen per categorie gezondheidsbevorderend gedrag (GBG) van ouders in vergelijking met de controlegroep (TO-T1 \& TO-T2). 


\section{Discussie}

\subsection{Samenvatting van de resultaten}

Het doel van deze studie was het effect van EU-Schoolfruit alleen, en in combinatie met Smaaklessen te onderzoeken op kennis over gezonde voeding en GF consumptie onder kinderen in groep 6 en 7. Daarnaast is er gekeken naar de waardering en implementatie van de programma's en de invloed van schoolbeleid en thuisomgeving op het effect van beide programma's.

De resultaten laten zien dat de kennis over gezonde voeding significant toenam bij kinderen die EUSchoolfruit en Smaaklessen hebben gehad, in vergelijking met kinderen die geen EU-Schoolfruit en Smaaklessen hebben gehad. Deze toename in kennis beklijfde zes maanden na blootstelling aan de programma's, en sluit aan bij eerder onderzoek naar de effectiviteit van Smaaklessen wat resulteerde in een significante toename in kennis door Smaaklessen (43). Daarnaast hadden EU-Schoolfruit en Smaaklessen geen direct significant effect op de GF consumptie van kinderen, maar er lijkt wel een effect te zijn binnen bepaalde subgroepen met betrekking tot de schoolomgeving (voedingsbeleid) en de thuisomgeving (gezondheidsbevorderend gedrag van ouders). Op scholen die geen voedingsbeleid hadden, was er een significant effect van het EU-Schoolfruitprogramma te zien op GF consumptie, terwijl op scholen met een voedingsbeleid geen effect gevonden werd. Daarnaast leek het effect van EU-Schoolfruit in combinatie met Smaaklessen op GF consumptie sterker bij kinderen met ouders die laag scoorden op gezondheidsbevorderend gedrag dan bij kinderen met ouders die hier hoog op scoorden.

Beide programma's zijn zowel door de kinderen als de leerkrachten positief beoordeeld, waarbij EUSchoolfruit hoger werd gewaardeerd wanneer Smaaklessen ook werd ingezet. Gemiddeld werden 2.9 lessen (van de totaal 5 aangeboden) ingezet en 33\% van de activiteiten van Smaaklessen, waaruit bleek dat het aantal uitgevoerde Smaaklessen positief geassocieerd is met het kennisniveau van de kinderen.

\subsection{Discussie van de gevonden resultaten}

Hieronder worden resultaten van het huidige onderzoek per uitkomstmaat besproken en vergeleken met de resultaten van eerder uitgevoerde vergelijkbare studies.

\subsubsection{Effect op kennis over voeding}

Uit de resultaten blijkt dat deelname aan Smaaklessen leidt tot een significante toename van kennis over gezonde voeding bij kinderen. De toename in kennis van kinderen bleek ook te beklijven op de langere termijn. Deze bevinding sluit aan bij de eerdere evaluatiestudie van Smaaklessen, waar de implementatie van Smaaklessen ook resulteerde in verhoging in kennis over voeding (43). Daarnaast was de verandering in kennis significant hoger wanneer er meer Smaaklessen zijn uitgevoerd, dan wanneer er minder lessen zijn uitgevoerd. Ook dit was op zowel de korte- als de lange termijn zichtbaar. Ondanks dat er gemiddeld 2.9 lessen van de aangeboden 5 lessen zijn uitgevoerd van Smaaklessen, heeft dit tot significant effect geleid. Er wordt daarom verwacht dat Smaaklessen een sterker effect op het kennisniveau zal hebben wanneer alle vijf aangeboden lessen uitgevoerd zouden zijn door de scholen in de EUS+SL groep. 
EU-Schoolfruit alleen heeft volgens huidig onderzoek geen effect op het kennisniveau van de kinderen. In tegenstelling tot de originele vorm van EU-Schoolfruit is in dit onderzoek het lesmateriaal van EU-Schoolfruit achterwege gelaten om de effecten van de afzonderlijke componenten (educatie en GF aanbod) te kunnen onderzoeken. EU-Schoolfruit zonder lesmateriaal bleek geen effect te hebben op kennis, terwijl de combinatie van EU-Schoolfruit met Smaaklessen wel een toename in kennis liet zien. Diverse studies laten vergelijkbare positieve effecten van voedseleducatie op kennis over voeding zien $(55,56,57,58)$. Echter konden de effecten van deze eerdere studies niet vergeleken worden aangezien de effecten anders zijn gerapporteerd. Daarnaast sluiten de resultaten van huidige studie aan bij een systematische review, waaruit bleek dat ongeveer een derde van de evaluatiestudies $(n=49)$ significante effecten van voedseleducatie op kennis over voeding rapporteerden (59).

\subsubsection{Effect op groente- en fruitconsumptie}

Voor zowel EU-Schoolfruit als Smaaklessen was geen significant effect op de groente- en fruitconsumptie bij kinderen gevonden. Resultaten van de 24-uurs recall laten aan het eind van het programma (T1 t.o.v. T0) echter een stijging van 29.7 gram (EUS groep) en 43.2 gram (EUS+SL groep) in de GF consumptie zien (zie Figuur 6). Hoewel deze resultaten niet significant waren, komt dit wel overeen met eerder onderzoek (25), waarbij werd gevonden dat dergelijke interventies op scholen gemiddeld een toename van 20 tot 30 gram in GF consumptie tot gevolg hebben.

Om de GF consumptie van kinderen te meten is gebruik gemaakt van de 24-uurs recall methode. Deze methode is volgens de literatuur een gevalideerde methode om GF inname te meten bij kinderen (47). Desondanks hadden veel kinderen moeite met het rapporteren van hun groente- en fruit inname van de voorgaande dag. Tijdens de meetmomenten gaven kinderen vaak aan het zich niet meer te herinneren en/of moeite te hebben met het inschatten van de porties. Andere methodes die in de literatuur worden gebruikt om de GF inname van kinderen nauwkeuriger te meten maken gebruik van weegmethodes (weighed records) of nemen de 24-uurs recall mondeling af (60).

Daarnaast zien we in de laatste meting (T2) dat bij scholen die alleen aan EU-Schoolfruit meededen de toename in GF consumptie bij kinderen beklijft. Daarentegen zien we bij scholen die meededen aan beide programma's (EUS+SL groep) juist een afname van GF consumptie. Dit verschil tussen de interventiegroepen is met de huidige resultaten niet te verklaren.

\subsubsection{Waardering EU-Schoolfruit en Smaaklessen}

Kinderen waardeerden EU-Schoolfruit en Smaaklessen positief, waaruit bleek dat ze het leuk vonden om deel te nemen aan de programma's. Er waren kleine verschillen in waardering tussen de interventiegroepen. Kinderen in de EUS+SL groep vonden EU-Schoolfruit iets interessanter, lekkerder, maar minder gemakkelijk in vergelijking met kinderen uit de EUS groep.

De leerkrachten waren ook positief over beide programma's, waarbij werd aangegeven dat ze het een leuk programma vonden om in te zetten en dat het goed georganiseerd was met voldoende informatie vooraf. De grootste belemmering die men noemde was dat het inzetten van de programma's tijd kost. Dit sluit aan bij eerder vergelijkbaar onderzoek wat ook liet zien dat leerkrachten aangaven weinig tijd te hebben om Smaaklessen in te zetten binnen het huidige curriculum (43). Alsnog gaven vrijwel alle leerkrachten aan door te willen gaan met beide programma's. Deze positieve waardering sluit aan bij het hoge aantal scholen die jaarlijks EU-Schoolfruit en/of Smaaklessen inzet.

\subsubsection{Implementatie Smaaklessen}

Smaaklessen is minder ingezet dan was voorgesteld, waarbij gemiddeld 2.9 lessen zijn ingezet van de aangeboden 5 lessen voor groep 6 en 7 . Van de 5 lessen zijn de eerste twee lessen (over zintuigen en productiewijze) het meest ingezet. Een verklaring hiervoor zou kunnen zijn dat deze lessen vooraan in het lesboek zaten en daardoor mogelijk het eerst uitgevoerd zijn. De lage inzet van lessen ten opzichte van het aanbod komt overeen met eerder onderzoek wat resulteerde in een implementatie van 3-4 lessen ten opzichte van de totaal 10-12 aangeboden lessen (54). 


\subsubsection{Invloed van voedingsbeleid}

De resultaten laten zien dat voedingsbeleid een rol lijkt te spelen in het effect van EU-Schoolfruit op GF consumptie. Alleen op scholen zonder voedingsbeleid werd een significant effect van EU-Schoolfruit op GF consumptie gevonden op de korte- en lange termijn. Op scholen met voedingsbeleid werden er geen significante veranderingen gevonden als gevolg van EU-Schoolfruit. Dit is niet in lijn met eerdere studies, waarin werd gesuggereerd dat voedingsinterventies effectiever zouden kunnen zijn wanneer deze worden ondersteund door voedingsbeleid $(51,61)$. Een verklaring hiervoor zou kunnen zijn dat bij EU-Schoolfruit het fruit dat wordt geleverd het anders zelf meegebrachte fruit vervangt. Fruit van EU-Schoolfruit dat wordt gegeten in de ochtendpauze brengt bij die kinderen dan weinig veranderingen teweeg in totale GF consumptie. Voor kinderen op scholen met geen actief voedingsbeleid zou EUSchoolfruit andere snacks in de ochtendpauze kunnen vervangen en daarbij kunnen bijdragen aan een hogere totale GF consumptie. Op deze scholen zou daarnaast gestimuleerd moeten worden dat ouders kinderen ook zelf groente en fruit meegeven naar school na afloop van het EU-Schoolfruitprogramma om te voorkomen dat kinderen terugvallen in oude gewoonten. Dit zou na EU-Schoolfruit gestimuleerd kunnen blijven worden door middel van een voedingsbeleid. Het is waarschijnlijk dat de effectiviteit van het voedingsbeleid daarbij sterk samenhangt met de mate waarmee het verankerd is in de school en wordt nageleefd door de ouders/verzorgers (36). Dit is niet meegenomen in het huidige onderzoek.

\subsubsection{Invloed van de ouders}

De resultaten van de eerste meting (TO) laten zien dat het meegeefgedrag van ouders en het stimuleren van gezond eten in de thuisomgeving een rol spelen bij de GF consumptie en voedingskennis van kinderen. Het vaak meegeven van GF was geassocieerd met een hogere GF consumptie en een hogere voedingskennis. Dit komt overeen met eerder onderzoek waaruit bleek dat de beschikbaarheid van groente en fruit een determinant is die positief gerelateerd is aan GF consumptie bij kinderen (62). Daarnaast wordt dit ook onderbouwd in een eerder literatuuronderzoek wat resulteerde in een positieve associatie tussen beschikbaarheid van GF en de GF consumptie bij kinderen (32).

Daarnaast was het beperkt meegeven van frisdrank/limonade geassocieerd met een hogere GF consumptie en een hogere voedingskennis bij kinderen. Dit komt overeen met een eerdere studie waaruit bleek dat kinderen in het hoogste tertiel van het drinken van frisdrank en/of limonade 0.5 portie minder fruit aten in vergelijking met kinderen die geen frisdrank en/of limonade dronken (63). Dit werd bevestigd door een ander literatuuronderzoek wat aantoonde dat het drinken van frisdrank geassocieerd is met een lagere fruit consumptie (64).

In lijn met de resultaten van frisdrank/limonade, is het beperkt meegeven van snoep/koek door ouders geassocieerd met een hogere GF consumptie bij kinderen. Eerder onderzoek liet een vergelijkbare associatie zien, waarbij kinderen die onbeperkt op school kunnen snacken minder vaak GF eten (65). Helpen met koken was ook geassocieerd met een hogere GF consumptie en een hogere voedingskennis. Deze resultaten worden ondersteund door eerdere studies waarin aangetoond werd dat het helpen bij koken in de thuisomgeving geassocieerd is met hogere GF consumptie bij kinderen $(66,67,68)$. Chu et al. (67) rapporteerden dat kinderen die dagelijks helpen met koken gemiddeld een portie groente of fruit meer eten in vergelijking met kinderen die nooit helpen met koken. In de huidige studie vonden we een verschil van $132 \mathrm{gram}$, wat overeenkomt met ongeveer 1.7 portie. Als laatst was praten over gezond eten ook geassocieerd met een hogere GF consumptie en een hogere voedingskennis bij kinderen. Ook dit komt overeen met eerder onderzoek, waarin praten over gezond eten in de thuisomgeving positief geassocieerd is met een verhoogde fruitconsumptie bij kinderen (69). Een andere vergelijkbare studie resulteerde in een zelfde positieve associatie voor zowel fruit- als groenteconsumptie bij kinderen (70).

Het onderzoek naar de invloed van gezondheidsbevorderend gedrag (GBG) op het effect van de programma's laat zien dat er met name een effect zichtbaar is bij kinderen van wie de ouders laag scoren op GBG. Een significante toename in GF consumptie als gevolg van EU-Schoolfruit in combinatie met Smaaklessen waren zichtbaar bij kinderen met ouders met laag GBG wat betreft het meegeven frisdrank/limonade, het meegeven van snoep/koek en het betrekken van kinderen bij het koken. Dit betekent dat EU-Schoolfruit in combinatie met Smaaklessen bijdragen aan een verhoging in GF consumptie bij kinderen die over het algemeen minder worden gestimuleerd om GF te eten in de thuisomgeving. 
Betreft de invloed van de thuisomgeving en voedingskennis was zowel in de laag als in de hoog GBG categorie een significante toename in kennis gevonden. Dit laat zien dat de invloed van beide programma's op kennis minder beïnvloed wordt door het GBG van ouders.

\subsection{Sterke punten en verbeterpunten}

Een sterk punt van dit onderzoek is dat er gebruik gemaakt is van veelal gevalideerde vragenlijsten $(43,46,47,53)$. De vragenlijst van Poelman et al. (53) om voedselvaardigheden van volwassenen te meten is aangepast, waarbij de nadruk is komen te liggen op het gezondheidsbevorderende gedrag van ouders ten aanzien van hun kinderen.

Een ander sterk punt is dat de vragenlijst door veel kinderen is ingevuld. Alle scholen en klassen die meededen aan T0 hebben ook aan de twee daaropvolgende metingen (T1 en T2) meegedaan. De vragenlijst is klassikaal afgenomen waardoor veel kinderen de vragenlijst hebben ingevuld. Ondanks dat sommige kinderen zijn uitgevallen door afwezigheid, het niet compleet invullen van de vragenlijst of bezwaar van ouders voor deelname, is de respons hoog.

In huidig onderzoek is gebruik gemaakt van een quasi-experimentele studieopzet met een controlegroep en een voormeting (TO). Het is daardoor aannemelijk dat gevonden resultaten toe te schrijven zijn aan EU-Schoolfruit en/of Smaaklessen. De deelnemende scholen zijn echter niet willekeurig ingedeeld aan de interventiegroep (EUS groep en/of EUS+SL groep) of de controlegroep. De controlegroep is namelijk op een andere manier geworven dan de scholen voor de interventiegroep. Ondanks deze verschillende manier van werven bleken de scholen vergelijkbaar op basis van de gemiddeldes in leeftijd, groep ( 6 en 7 ) en geslacht. Wel waren kleine verschillen zichtbaar in sociaal-economische positie, het soort voedingsbeleid, de grondslag, de grootte en de plaats van de school.

Op basis van eerder vergelijkbaar onderzoek is besloten dat er ongeveer 1200 kinderen aan het onderzoek mee zouden moeten doen om eventuele effecten statistisch aan te kunnen tonen (43), waarbij 600 kinderen in de interventiegroep en 600 kinderen in de controlegroep. Deze aantallen zijn nagenoeg gehaald, waarbij de controlegroep iets kleiner is en de twee interventiegroepen groter zijn dan de aanbevolen groottes. De analyses per subgroep zijn echter uitgevoerd met kleinere aantallen waardoor verbanden moeilijker zijn aan te tonen. Enige voorzichtigheid is daarom op zijn plaats bij het trekken van conclusies van de analyses die gestratificeerd zijn naar voedingsbeleid en GBG van ouders.

\subsection{Conclusie}

EU-Schoolfruit in combinatie met Smaaklessen is effectief in het verhogen van kennis over gezonde voeding, maar niet in het verhogen van GF consumptie bij kinderen. Wel zagen we dat de programma's kunnen bijdragen aan een toename in GF consumptie bij kinderen op scholen waar nog geen voedingsbeleid wordt ingezet, en bij kinderen uit een thuisomgeving waarbij gezond eetgedrag weinig gestimuleerd wordt. 


\section{Aanbevelingen}

\subsection{Praktijk}

- Smaaklessen als aanvulling op EU-Schoolfruit is nodig om effect te bereiken op kennis. Hogere implementatiegraad van lessen leidt tot sterker effect op kennis.

- In lijn met eerder onderzoek leidt een inzet van EU-Schoolfruit tot een verhoging van ongeveer 0,30 portie. Deze toename in de totale onderzoeksgroep is niet significant en spitst zich toe op specifieke groepen, namelijk scholen die geen voedingsbeleid hebben en kinderen waarbij ouders laag GBG vertonen.

- De verschillende componenten GF aanbod, beleid en educatie vullen elkaar maar gedeeltelijk aan. Educatie vormt een aanvulling op GF aanbod, maar voedingsbeleid is dat niet. EU-Schoofruit lijkt vooral een meerwaarde te hebben op scholen en in gezinnen waar verder niet veel aandacht is voor gezonde (op)voeding.

- Dit kan zich vertalen in:

1. het stimuleren van volledige implementatie van Smaaklessen op scholen

2. gerichte inzet van EU-Schoolfruit voor specifieke groepen

3. scholen stimuleren om meer aandacht te besteden aan de ontwikkeling van een voedingsbeleid.

\subsection{Wetenschap}

We bevelen aan om verder onderzoek te doen naar de volgende punten:

- De implementatie van voedingsbeleid: beter begrip van de verankering van beleid in de school (communicatie, naleving).

- De invloed van de thuisomgeving op kennis en GF consumptie bij kinderen.

- Het meten van de daadwerkelijke groente- en fruitconsumptie op school en thuis. 


\section{Referenties}

1. Bammann K, Peplies J, Pigeot I, Ahrens W. IDEFICS: a multicenter European project on diet- and lifestyle-related disorders in children. Medizinische Klinik (Munich, Germany: 1983). 2007;102(3):230-5.

2. Sahoo, K., et al., Childhood obesity: Causes and consequences. Journal of Family Medicine and Primary Care, 2015. 4(2): p. 187-192.

3. World Health Organisation (WHO). (2018) Healthy Diet. Retrieved February 10, 2019 from: https://www.who.int/news-room/fact-sheets/detail/healthy-diet

4. Voedingscentrum. (2020.). Schijf van Vijf. Geraadpleegd op 9 april 2020, van: https://www.voedingscentrum. nl/nl/gezond-eten-met-de-schijf-van-vijf/hoeveel-en-wat-kan-ikper-dag-eten-.aspx

5. Centraal Bureau voor de Statistiek. (2018). Ervaren gezondheid, zorggebruik en leefstijl bij kinderen tot 12 jaar. Geraadpleegd op 9 april 2020, van: https://opendata.cbs.nl/statline/\#/CBS/nl/dataset/83716NED/table?ts=1580730293011

6. Scriven, A., \& Hodgins, M. (Eds.). (2011). Health promotion settings: principles and practice. Sage.

7. FAO. (2005). Nutrition Education in Primary Schools (Vol. 1). https://doi.org/10.1177/15648265050262S208

8. Dehghan, M., Akhtar-Danesh, N., Merchant, A. (2005). Childhood obesity, prevalence and prevention. Nutrition Journal., 4(1), 24. doi: 10.1186/1475-2891-4-24

9. Bartholomew, L.K. Planning. (2011). Health Promotion Programs: An Intervention Mapping Approach. San Francisco, CA: Jossey-Bass

10. Black, J.L., Velazquez, C.E., Ahmadi, N., Chapman, G.E., Carten, S., Edward, J., Shulhan, S., Stephens, T., \& Rojas, A. (215). Sustainability and public health nutrition at school: assessing the integration of healthy and environmentally sustainable food initiatives in Vancouver schools. Public Health Nutrition, 18(13), 1-13, doi: 10.1017/S1368980015000531.

11. Dudley, D., Cotton, W., Peralta, L. (2015). Teaching approaches and strategies that promote healthy eating in primary school children: a systematic review and meta-analysis. International Journal of Behavioral Nutrition and Physical Activity, 12(1), 28. doi: 10.1186/s12966-015-0182-8

12. Wall DE, Least C, Gromis J, Lohse B. Nutrition education intervention improves vegetable-related attitude, self-efficacy, preference, and knowledge of fourth-grade students. Journal of School Health. 2012;82(1):37-43.

13. Baranowski T, Davis M, Resnicow K, Baranowski J, Doyle C, Lin LS, et al. Gimme 5 fruit, juice, and vegetables for fun and health: outcome evaluation. Health Education \& Behavior. 2000;27(1): 96-111.

14. Keihner AJ, Meigs R, Sugerman S, Backman D, Garbolino T, Mitchell P. The power play! Campaign's school idea \& resource kits improve determinants of fruit and vegetable intake and physical activity among fourth- and fifth-grade children. Journal of Nutrition Education and Behavior. 2011;43(4, Supplement 2):S122-S9.

15. Liquori T, Koch PD, Contento I, Castle J. The cookshop program: outcome evaluation of a nutrition education program linking lunchroom food experiences with classroom cooking experiences. Journal of Nutrition Education. 1998;30(5):302-13.

16. Auld GW, Romaniello C, Heimendinger J, Hambidge C, Hambidge M. Outcomes from a schoolbased nutrition education program using resource teachers and cross-disciplinary models. Journal of Nutrition Education. 1998;30(5):268-80.

17. Morris JL, Zidenberg-Cherr S. Garden-enhanced nutrition curriculum improves fourth-grade school children's knowledge of nutrition and preferences for some vegetables. Journal of the American Dietetic Association. 2002;102(1):91-3.

18. Prelip M, Kinsler J, Thai CL, Erausquin JT, Slusser W. Evaluation of a school-based multicomponent nutrition education program to improve young children's fruit and vegetable consumption. Journal of Nutrition Education and Behavior. 2012;44(4):310- 18. 
19. DelCampo D, Baca JS, Jimenez D, Sánchez PR, DelCampo R. Just be it! Healthy and fit increases fifth graders' fruit and vegetable intake, physical activity, and nutrition knowledge. Journal of Extension. 2011;49(1).

20. Bere E, Veierød MB, Bjelland M, Klepp K-I. Outcome and process evaluation of a Norwegian school-randomized fruit and vegetable intervention: Fruits and Vegetables Make the Marks (FVMM). Health Education Research. 2006;21(2):258-67.

21. Anderson A, Porteous L, Foster E, Higgins C, Stead M, Hetherington M, et al. The impact of a school-based nutrition education intervention on dietary intake and cognitive and attitudinal variables relating to fruits and vegetables. Public Health Nutrition. 2005;8(06):650-6.

22. Bontrager Yoder AB, Liebhart JL, McCarty DJ, Meinen A, Schoeller D, Vargas C, et al. Farm to elementary school programming increases access to fruits and vegetables and increases their consumption among those with low intake. Journal of Nutrition Education and Behavior. 2014;46(5):341-9.

23. Contento IR, Manning AD, Shannon B. Research perspective on school-based nutrition education. Journal of Nutrition Education. 1992;24(5):247-60.

24. Mak, T. N., Storcksdieck Genannt Bonsmann, S., \& Caldeira, S. (2016). How to promote fruit and vegetable consumption in schools: A toolkit (No. EUR 27946). https://doi.org/10.2788/33817

25. Evans, C. E., Christian, M. S., Cleghorn, C. L., Greenwood, D. C., \& Cade, J. E. (2012). Systematic review and meta-analysis of school-based interventions to improve daily fruit and vegetable intake in children aged 5 to 12 y. The American journal of clinical nutrition, 96(4), 889-901. https://doi.org/10.3945/ajcn.111.030270

26. Story, M., Kaphingst, K. M., Robinson-O'Brien, R., \& Glanz, K. (2008). Creating healthy food and eating environments: policy and environmental approaches. Annu. Rev. Public Health, 29, 253-272. doi:10.1146/annurev.publhealth.29.020907.090926

27. Larson, N., \& Story, M. (2009). A review of environmental influences on food choices. Annals of Behavioral Medicine, 38(suppl_1), s56-s73. doi: 10.1007/s12160-009-9120-9.

28. Song, H. J., Grutzmacher, S., \& Munger, A. L. (2016). Project ReFresh: Testing the Efficacy of a School-Based Classroom and Cafeteria Intervention in Elementary School Children. Journal of School Health, 86(7), 543-551. https://doi.org/10.1111/josh.12404

29. Kristjansdottir, A. G., Johannsson, E., \& Thorsdottir, I. (2010). Effects of a school-based intervention on adherence of 7-9-year-olds to food-based dietary guidelines and intake of nutrients. Public Health Nutrition, 13(8), 1151-1161. https://doi.org/10.1017/S1368980010000716

30. Te Velde, S. J., Brug, J., Wind, M., Hildonen, C., Bjelland, M., Pérez-Rodrigo, C., \& Klepp, K. I. (2008). Effects of a comprehensive fruit- and vegetable-promoting school-based intervention in three European countries: the Pro Children Study. British Journal of Nutrition, 99(04), 893-903. https://doi.org/10.1017/S000711450782513X

31. Van Rossum, C. T. M, Buurma-Rethans, E. J. M., Vennemann, F. B. C., Beukers, M., Brants, H. A. M., De Boer, E. J., \& Ocké, M. C. (2016). The diet of the Dutch: Results of the first two years of the Dutch National Food Consumption Survey 2012-2016 (RIVM Letter report No. 2016-0082). Bilthoven: RIVM

32. Pearson, N., Biddle, S. J., \& Gorely, T. (2008). Family correlates of fruit and vegetable consumption in children and adolescents: a systematic review. Public health nutrition, 12(2), 267-283. doi:10.1017/S1368980008002589

33. Racey, M., O’Brien, C., Douglas, S., Marquez, O., Hendrie, G., \& Newton, G. (2016). Systematic review of school-based interventions to modify dietary behavior: does intervention intensity impact effectiveness? Journal of School Health, 86(6), 452-463. https://doi.org/10.1111/josh.12396

34. Van Cauwenberghe, E., Maes, L., Spittaels, H., van Lenthe, F. J., Brug, J., Oppert, J. M., \& De Bourdeaudhuij, I. (2010). Effectiveness of school-based interventions in Europe to promote healthy nutrition in children and adolescents: systematic review of published and 'grey' literature. British journal of nutrition, 103(6), 781-797. doi:10.1017/S0007114509993370

35. Morgan, E. H., Schoonees, A., Sriram, U., Faure, M., \& Seguin-Fowler, R. A. (2020). Caregiver involvement in interventions for improving children's dietary intake and physical activity behaviors. Cochrane Database of Systematic Reviews, (1). https://doi.org/10.1002/14651858.CD012547.pub2 
36. Van Ansem, W.J.C., Schrijvers, C.T.M., Rodenburg, G., Schuit, A.J., \& Van de Mheen, D. (2013). School food policy at Dutch primary schools: room for improvement? Cross-sectional findings from the INPACT study. BMC Public Health, 13(339). doi: 10.1186/1471-2458-13-339

37. Haddad, J., Ullah, S., Bell, L., Leslie, E., \& Magarey, A. (2018). The influence of home and school environments on children's diet and physical activity, and body mass index: a structural equation modelling approach. Maternal and child health journal, 22(3), 364-375.

38. Chriqui, J. F., Pickel, M., \& Story, M. (2014). Influence of school competitive food and beverage policies on obesity, consumption, and availability: a systematic review. JAMA pediatrics, 168(3), 279-286. doi: 10.1001/jamapediatrics.2013.4457

39. Micha R, Karageorgou D, Bakogianni I et al. (2018) Effectiveness of school food environment policies on children's dietary behaviors: A systematic review and meta-analysis. PLoS One, 13, e0194555-e0194555

40. Kovacs, V. A., Messing, S., Sandu, P., Nardone, P., Pizzi, E., Hassapidou, M., ... \& Abu-Omar, K. (2020). Improving the food environment in kindergartens and schools: An overview of policies and policy opportunities in Europe. Food Policy. https://doi.org/10.1016/j.foodpol.2020.101848

41. Steunpunt Smaaklessen \& EU-Schoolfruit (2018). EU-Schoolfruit- en groenteprogramma, Werkblad beschrijving interventie. Wageningen: Wageningen UR

42. Van Coeverden, E. B., \& Schaap, A. (2017). Procesevaluatie Smaaklessen \& Smaakmissies: Onderzoek naar gebruik en waardering. Wageningen: Steunpunt Smaaklessen

43. Battjes-Fries, M., Dongen, E. van, \& Haveman-Nies, A. (2013). Evaluatie van smaaklessen: heeft smaaklessen effect op determinanten van gezond en bewust eetgedrag? Wageningen: Wageningen UR, Leerstoelgroep Humane Voeding

44. Dienst Uitvoering Onderwijs. (2018). Adressen alle schoolvestigingen in het basisonderwijs. Opgehaald op 01-06-2018 via:

https://duo.nl/open_onderwijsdata/databestanden/po/adressen/adressen-po-3.jsp

45. Sociaal en Cultureel Planbureau (SCP). (2012). Statusscores. Geraadpleegd in 2016, van: www.scp.nl

46. Vereecken, C., De Pauw, A., Van Cauwenbergh, S., \& Maes, L. (2012). Development and testretest reliability of a nutrition knowledge questionnaire for primary-school children. Public health nutrition, 15(9), 1630-1638.

47. Haraldsdóttir, J., Thórsdóttir, I., de Almeida, M. D. V., Maes, L., Pérez Rodrigo, C., Elmadfa, I., \& Frost Andersen, L. (2005). Validity and reproducibility of a precoded questionnaire to assess fruit and vegetable intake in European 11- to 12-year-old schoolchildren. Annals of Nutrition \& Metabolism, 49(4), 221-227. https://doi.org/10.1159/000087276

48. Donders-Engelen, M., Van der Heijden, L., \& Hulshof, K. F. A. M. (2003). Maten, gewichten en codenummers 2003. Wageningen: Division of Human Nutrition; Wageningen UR, Leerstoelgroep Humane Voeding en Zeist: TNO

49. Van Rossum, C., Fransen, H., Verkaik-Kloosterman, J., Buurma-Rethans, E., \& Ocke, M. (2011). Dutch National Food Consumption Survey 2007-2010: Diet of children and adults aged 7 to 69 years. Bilthoven: RIVM

50. RIVM. (2016). Overzicht recepten NEVO - online 2016 / List of recipes NEVO online 2016. Geraadpleegd op 20 november 2018, van https://www.rivm.nl/sites/default/files/201811/Recepten\%20NEVO-online\%202016.pdf

51. Battjes-fries, M. C. E., Dongen, E. J. I. Van, Renes, R. J., Meester, H. J., \& Veer, P. Van. (2016). Unravelling the effect of the Dutch school-based nutrition programme Taste Lessons: the role of dose, appreciation and interpersonal communication. BMC Public Health, 16(737), 1-8. https://doi.org/10.1186/s12889-016-3430-1

52. Voedingscentrum (2020). Voedingsbeleid op de basisschool. Geraadpleegd op 15 april 2020, van https://www.voedingscentrum.nl/professionals/gezond-op-school/basisonderwijs/voedingsbeleidop-de-basisschool.aspx

53. Poelman, M. P., Dijkstra, S. C., Sponselee, H., Kamphuis, C. B., Battjes-Fries, M. C., Gillebaart, M., \& Seidell, J. C. (2018). Towards the measurement of food literacy with respect to healthy eating: the development and validation of the self perceived food literacy scale among an adult sample in the Netherlands. International Journal of Behavioral Nutrition and Physical Activity, 15(1), 54. https://doi.org/10.1186/s12966-018-0687-z 
54. Battjes-Fries, M. C., Haveman-Nies, A., Renes, R. J., Meester, H. J., \& van't Veer, P. (2015). Effect of the Dutch school-based education programme 'Taste Lessons' on behavioural determinants of taste acceptance and healthy eating: a quasi-experimental study. Public health nutrition, 18(12), 2231-2241. https://doi.org/10.1017/S1368980014003012

55. Warren JM, Henry CJ, Lightowler HJ, Bradshaw SM, Perwaiz S. Evaluation of a pilot school programme aimed at the prevention of obesity in children. Health Promot Int. 2003;18(4):287-96.

56. Reynolds, K.D., Franklin, F.A., Binkley, D., Raczynski, J.M., Harrington, K.F., Kirk, K.A., Person, S. (2000). Increasing the fruit and vegetable consumption of fourth-graders: results from the High 5 project. Preventive Medicine, 30(4), 309-319. doi: 10.1006/pmed.1999.0630

57. Caballero B, Clay T, Davis SM, Ethelbah B, Rock BH, Lohman T, et al. Pathways: a schoolbased, randomized controlled trial for the prevention of obesity in American Indian schoolchildren. The American Journal of Clinical Nutrition. 2003;78(5):1030-8.

58. De Villiers, A., Steyn, N. P., Draper, C. E., Hill, J., Gwebushe, N., Lambert, E. V., \& Lombard, C. (2016). Primary school children's nutrition knowledge, self-efficacy, and behavior, after a threeyear healthy lifestyle intervention (HealthKick). Ethnicity \& disease, 26(2), 171.

59. Dudley, D., Cotton, W., Peralta, L. (2015). Teaching approaches and strategies that promote healthy eating in primary school children: a systematic review and meta-analysis. International Journal of Behavioral Nutrition and Physical Activity, 12(1), 28. doi: 10.1186/s12966-015-0182-8

60. Rutishauser, I. H. E. (2005). Dietary intake measurements. Public Health Nutrition, 8(7A), 1100-1107. https://doi.org/10.1079/PHN2005798

61. Beenackers M., Nusselder, W., Oude Groeniger, J., \& Van Lenthe, F. (2015). Het terugdringen van gezondheidsachterstanden: een systematisch overzicht van kansrijke en effectieve interventies. Rotterdam: Erasmus MC Universitair Medisch Centrum

62. Blanchette, L., \& Brug, J. (2005). Determinants of fruit and vegetable consumption among 6-12-year-old children and effective interventions to increase consumption. Journal of human nutrition and dietetics, 18(6), 431-443. https://doi.org/10.1111/j.1365-277X.2005.00648.x

63. Cullen, K. W., Ash, D. M., Warneke, C., \& De Moor, C. (2002). Intake of soft drinks, fruit-flavored beverages, and fruits and vegetables by children in grades 4 through 6 . American Journal of Public Health, 92(9), 1475-1477.

64. Vartanian, L. R., Schwartz, M. B., \& Brownell, K. D. (2007). Effects of soft drink consumption on nutrition and health: a systematic review and meta-analysis. American journal of public health, 97(4), 667-675.

65. Gonzalez, W., Jones, S. J., \& Frongillo, E. A. (2009). Restricting snacks in US elementary schools is associated with higher frequency of fruit and vegetable consumption. The Journal of Nutrition, 139(1), 142-144. https://doi.org/10.3945/jn.108.099531

66. Berge, J. M., MacLehose, R. F., Larson, N., Laska, M., \& Neumark-Sztainer, D. (2016). Family food preparation and its effects on adolescent dietary quality and eating patterns. Journal of Adolescent Health, 59(5), 530-536.

67. Chu, Y. L., Storey, K. E., \& Veugelers, P. J. (2014). Involvement in meal preparation at home is associated with better diet quality among Canadian children. Journal of nutrition education and behavior, 46(4), 304-308.

68. De Jong, E., Visscher, T. L. S., HiraSing, R. A., Seidell, J. C., \& Renders, C. M. (2015). Home environmental determinants of children's fruit and vegetable consumption across different SES backgrounds. Pediatric obesity, 10(2), 134-140.

69. Vereecken, C. A., Keukelier, E., \& Maes, L. (2004). Influence of mother's educational level on food parenting practices and food habits of young children. Appetite, 43(1), 93-103.

70. Verjans-Janssen, S., Van Kann, D., Kremers, S., Vos, S., Jansen, M., \& Gerards, S. (2019). A cross-sectional study on the relationship between the family nutrition climate and children's nutrition behavior. Nutrients, 11(10), 2344. 


\section{Bijlage 1 Vragenlijst voor de kinderen (groep 6-8)}

\section{Vragenlijst over eten en drinken}

\section{Hoi!}

Je gaat wat vragen invullen over eten en drinken. Dat wordt in deze vragen producten genoemd.

Dit is geen toets, dus er zijn geen goede of foute antwoorden. Geef daarom een eerlijk antwoord op elke vraag en vul hem voor jezelf in. Je mag niet overleggen met je klasgenootjes!

Bij elke vraag wordt uitgelegd hoe je de vraag moet invullen. Je moet bijvoorbeeld het juiste antwoord omcirkelen.

Als voorbeeld: Wat is jouw lievelingsdier?

- Hond

- Poes

- Konijn

- Hamster

Wanneer je een antwoord wilt veranderen, geef je dit zo aan:

CHond

- Poes

- Konijn

- Hamster

Veel plezier met het invullen! 


\section{Informatie over jou}

Hoe heet je?

Ik heet:

Op welke school zit je?

Mijn school heet:

Ben je een jongen of een meisje?

- Jongen

- Meisje

In welke groep zit je?

- groep 5

- groep 6

- groep 7

- groep 8

\section{Hoe oud ben je?}

Ik ben jaar oud 


\section{Wat is het meest gezond?}

Wat is het meest gezond? Met gezonde producten bedoelen we producten die goed zijn voor je lichaam.

Omcirkel het goede antwoord:

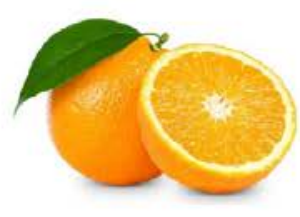

- Sinaasappel

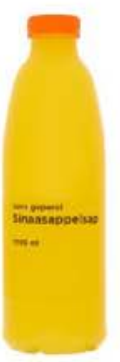

- Sinaasappelsap

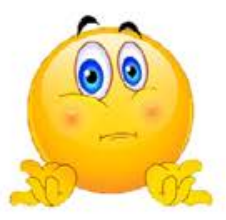

- Ik weet het niet

Wat is het meest gezond om in te bakken? Omcirkel het goede antwoord:

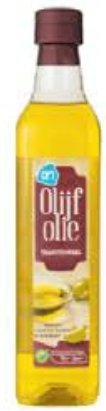

- Olijfolie

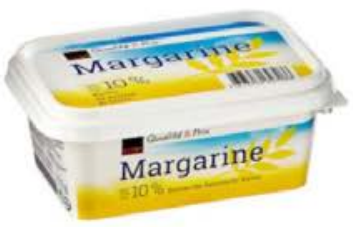

- Margarine
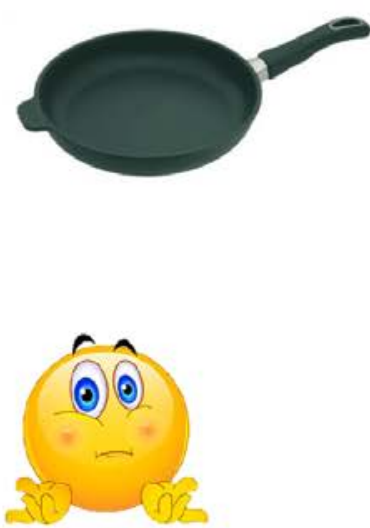

- Ik weet het niet 
Wat is het meest gezond om te snacken?

Omcirkel het goede antwoord:

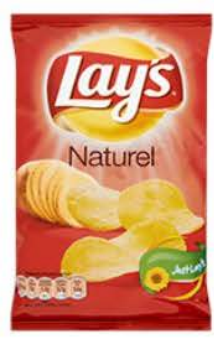

- Chips

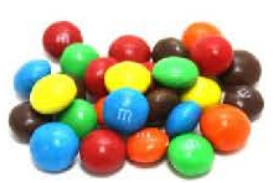

- $M \& M^{\prime} s$

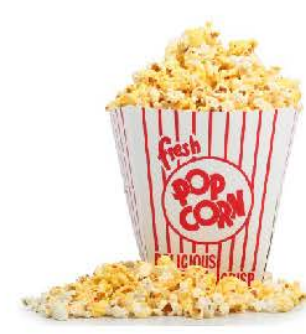

- Popcorn

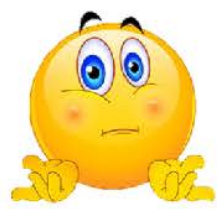

- Ik weet het niet

Wat is het meest gezond om te drinken?

Omcirkel het goede antwoord:

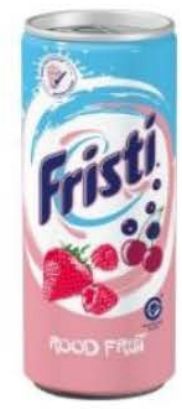

- Fristi

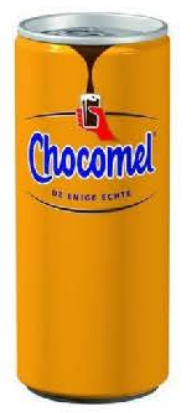

- Chocolademelk

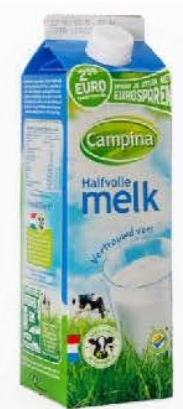

- Melk

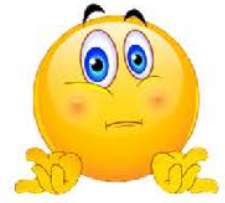

- Ik weet het niet 


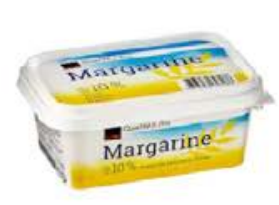

- Margarine

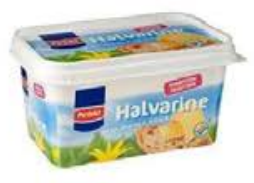

- Halvarine

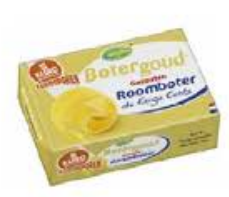

- Roomboter

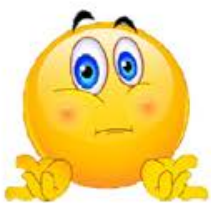

- Ik weet het niet

\section{De Schijf van Vijf}

\section{Ken je de Schijf van Vijf?}

- Ja, die ken ik en ik weet wat er in staat

- Ja, daar heb ik wel eens van gehoord

- Nee, die ken ik niet

\section{Uitleg}

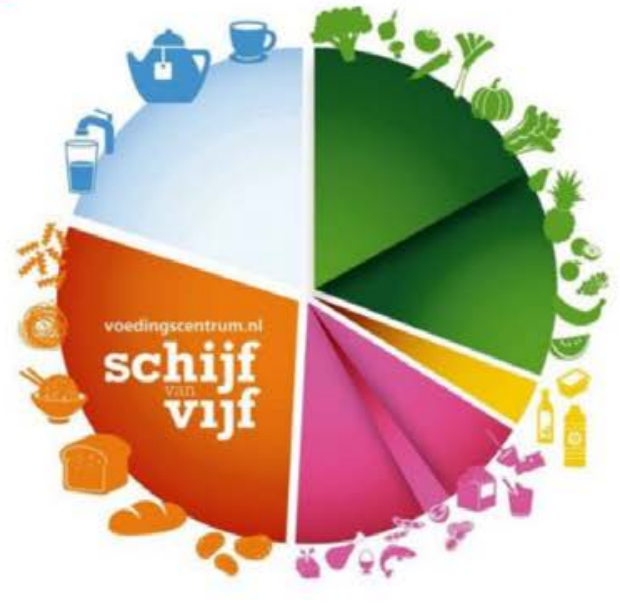

De Schijf van Vijf bevat 5 vakken met groepen gezonde producten. Bijvoorbeeld: in het groene vak zitten groente en fruit en in het blauwe vak zit het drinken, zoals water en melk. Je hebt deze producten nodig om te groeien en gezond te blijven. Bij elk vak staat hoeveel je ervan nodig hebt. 


\section{Hoeveel heb jij nodig?}

Hoeveel fruit heb jijzelf (leeftijd 8-11 jaar) elke dag nodig om te groeien en gezond te blijven volgens de Schijf van Vijf?

Omcirkel het goede antwoord:

- een half stuk fruit

- 1 stuk fruit

- 1.5 - 2 stuks fruit

- 2 - 3 stuks fruit

- 4 stuks fruit

- Ik weet het niet

Hoeveel groente heb jijzelf (leeftijd 8-11 jaar) elke dag nodig om te groeien en gezond te blijven volgens de Schijf van Vijf?

Omcirkel het goede antwoord:

- 0-50 gram groente

- 50-100 gram groente

- 100-200 gram groente

- 200-300 gram groente

- 300-350 gram groente

- Ik weet het niet

Hoeveel water moet jijzelf (leeftijd 8-11 jaar) elke dag drinken om te groeien en gezond te blijven volgens de Schijf van Vijf?

Omcirkel het goede antwoord:

- 0.5 liter tot 1 liter drinken

- 1 liter tot 1.5 liter drinken

- 1.5 liter tot 2 liter drinken
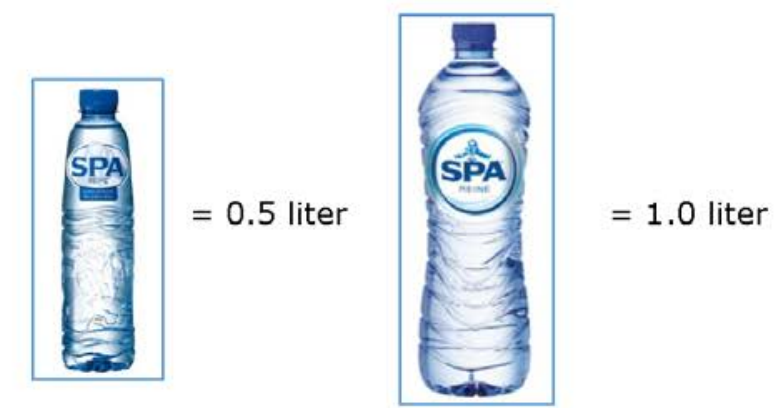

- Ik weet het niet 
Als je brood eet, hoeveel sneetjes brood heb jijzelf (8-11 jaar) per dag nodig om te groeien en gezond te blijven volgens de Schijf van Vijf?

Omcirkel het goede antwoord:

- 1-2 sneetjes

- 2-4 sneetjes

- 4-6 sneetjes

- 6-7 sneetjes

- 7-8 sneetjes

- Ik weet het niet

Als je aardappelen eet, hoeveel aardappelen heb jijzelf (8-11 jaar) per dag nodig om te groeien en gezond te blijven volgens de Schijf van Vijf?

Omcirkel het goede antwoord:

- 1-2 stuks

- 2-3 stuks

- 3-5 stuks

- 5-6 stuks

- 6-7 stuks

- Ik weet het niet

\section{Wat lijkt jou het meest gezonde bord met avondeten?}

Omcirkel het goede antwoord:

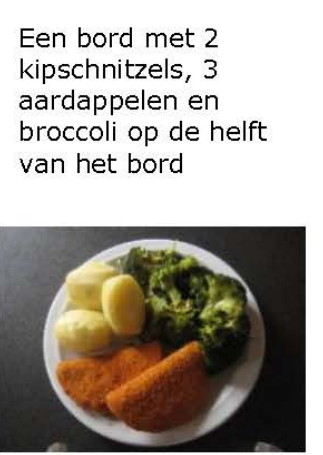

- bord 1
Een bord met 1 kipschnitzel, 3 aardappelen en broccoli op een kwart van het bord

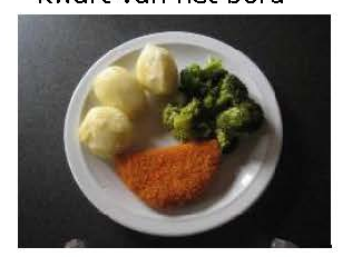

- bord 2

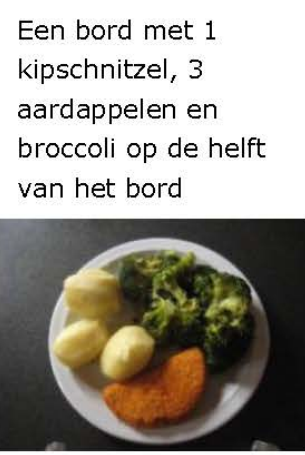

- bord 3
Een bord met 2 kipschnitzels, 2 aardappelen en broccoli op een kwart van het bord

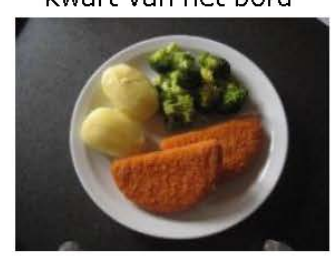

- bord 4 


\section{Vitamines en Mineralen}

\section{Uitleg}

Vitamines en mineralen zijn stoffen die in kleine hoeveelheden in eten en drinken zitten. Je hebt ze nodig om goed te groeien.

In volkorenbrood zitten ...

Omcirkel het goede antwoord:

- Minder vitamines en mineralen dan in wit brood

- Evenveel vitamines en mineralen als in wit brood

- Meer vitamines en mineralen dan in wit brood

- Ik weet het niet

\section{Waarom is het belangrijk om melk te drinken?}

Omcirkel het goede antwoord:

- Melk is goed voor een gezonde huid en ogen

- Melk is goed voor je botten en tanden

- Door melk word je minder snel ziek

- Ik weet het niet

\section{Waarom zijn vitamines in fruit en groente belangrijk?}

Omcirkel het goede antwoord:

- In vitamines zit veel energie

- Vitamines zorgen ervoor dat je goed kunt poepen

- Door vitamines word je minder snel ziek

- Ik weet het niet 


\section{Waarom zijn vezels (uit bijvoorbeeld volkorenbrood) belangrijk?}

Omcirkel het goede antwoord:

- In vezels zit veel energie

- Van vezels krijg je veel spieren

- Vezels zorgen ervoor dat je goed kunt poepen

- Ik weet het niet

\section{Waarom is het belangrijk om aardappelen te eten?}

Omcirkel het goede antwoord:

- In aardappelen zit veel energie

- Van aardappelen krijg je veel spieren

- Aardappelen zijn goed voor een gezonde huid en ogen

- Ik weet het niet 


\section{Groepen in de Schijf van Vijf}

De Schijf van Vijf bevat 5 vakken met groepen gezonde producten. De volgende vragen gaan over welke producten in welke vakken horen.

\section{Welk plaatje hoort er niet bij?}

Omcirkel het goede antwoord:
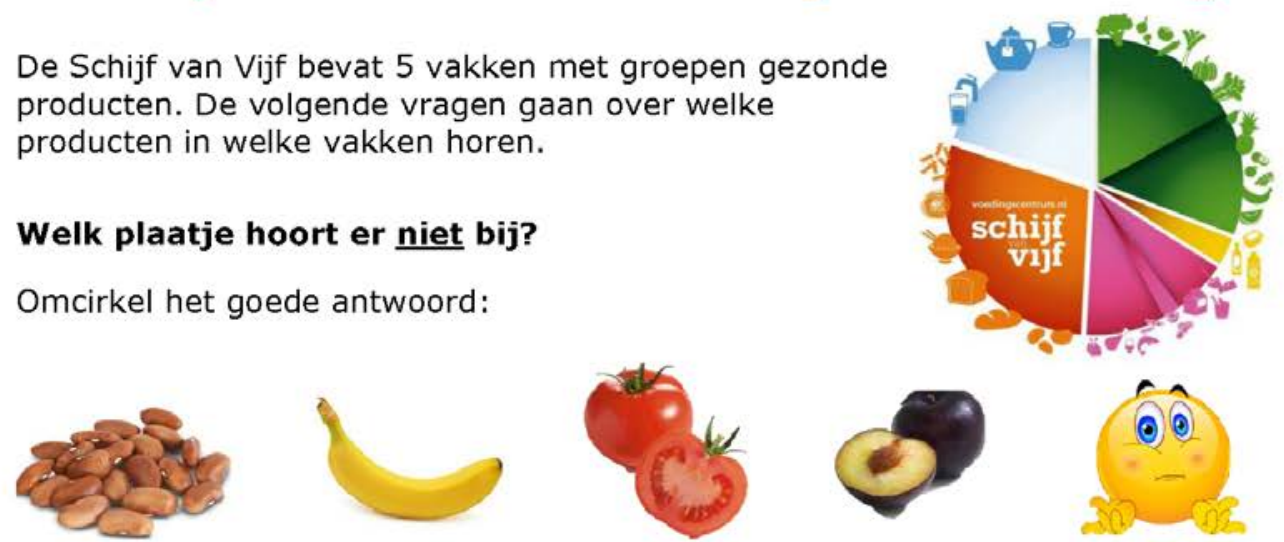

- Bruine bonen

- Banaan

- Tomaat

- Pruim

- Ik weet het niet

\section{Welk plaatje hoort er niet bij?}

Omcirkel het goede antwoord:
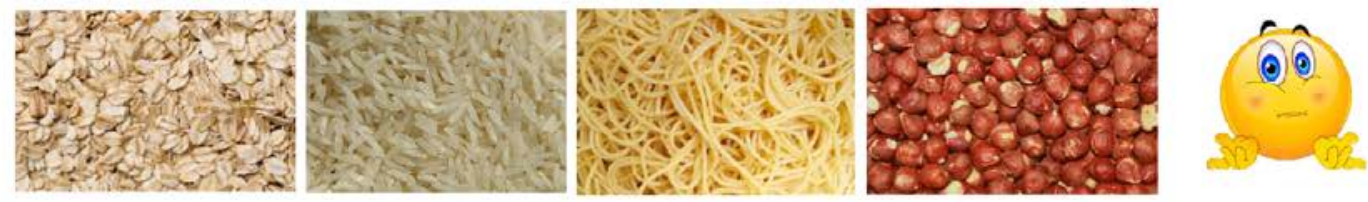

- Havermout

- Rijst

- Pasta

- Hazelnoten

- Ik weet het niet

\section{Welk plaatje hoort er niet bij?}

Omcirkel het goede antwoord:

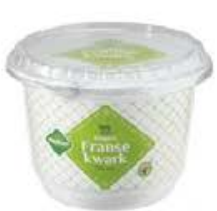

- Kwark

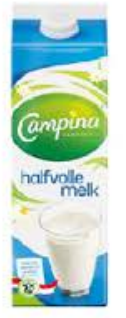

- Melk

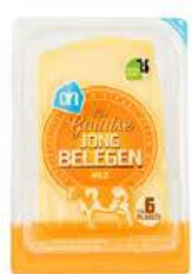

- Kaas

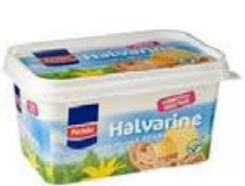

- Halvarine

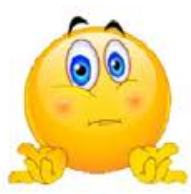

- Ik weet het niet 


\section{Zintuigen}

Met je tong kun je proeven of ergens zout in zit

Omcirkel het goede antwoord:
- Waar
- Niet waar
- Weet ik niet

Het maakt niet uit of je neus open of dicht zit, je proeft altijd evenveel Omcirkel het goede antwoord:
- Waar
- Niet waar
- Weet ik niet

Als iets lekker ruikt, gaat het speeksel in je mond lopen Omcirkel het goede antwoord:
- Waar
- Niet waar
- Weet ik niet

Als ik iets proef, kan ik zeggen of het zoet, zuur, bitter of zout is Omcirkel het goede antwoord:

- Ja $\bullet$ Een beetje Nee

\section{Biologisch}

Op biologische producten zitten dezelfde bestrijdingsmiddelen als op gewone producten

Omcirkel het goede antwoord:

- Waar - Niet waar - Weet ik niet

Welk keurmerk past niet goed bij de rest?

Omcirkel het goede antwoord:

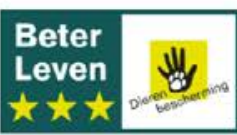

- Keurmerk 1

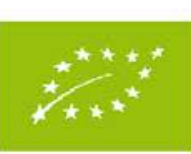

- Keurmerk 2

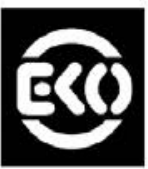

- Keurmerk 3

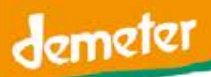

- Keurmerk 4 Ik weet het niet

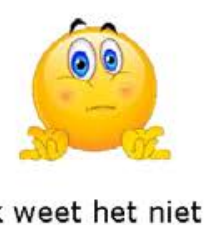




\section{Wat heb jij gisteren gegeten?}

\section{Welke dag was het gisteren?}

Gisteren was het

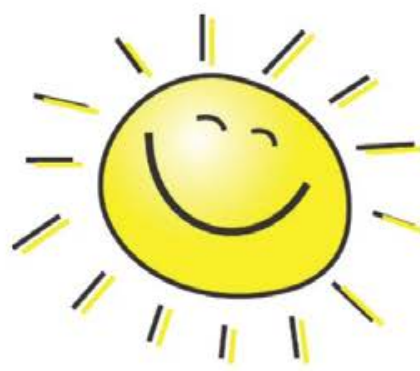

\section{In de}

Heb je gisteren ontbijt gehad of iets in de kleine pauze gegeten?

- Ja

- Nee

Zo ja, heb je gisteren tijdens je ontbijt of in de kleine pauze fruit of groente gegeten?

- Ja Nee

\section{Zo ja, wat voor fruit of groente? En hoeveel heb je daarvan gegeten?}

Schrijf 1 als je 1 hele appel hebt gegeten, schrijf een half als je een halve appel hebt gegeten. Als jouw fruit of groente niet in de tabel staat, kun je dat in de tabel zelf invullen.

\begin{tabular}{|c|c|c|c|c|c|}
\hline \multicolumn{3}{|c|}{ Fruit in de ochtend } & \multicolumn{3}{|c|}{ Groente in de ochtend } \\
\hline Appel & $\ldots$ & Stuk & Komkommer & .............. & Schijfjes \\
\hline Banaan & ............... & Stuk & Snoeptomaatje & ............... & Stuks \\
\hline Mandarijn & .............. & Stuk & Paprika & .......... & Reepjes \\
\hline Druiven & ........... & Handje & Wortel & $\ldots$ & Stuk \\
\hline Gesneden fruit & $\ldots \ldots$. & Bakje & Gesneden groente & & Bakje \\
\hline n.......... & n............ & ......... & n.......... & .............. & ........ \\
\hline n........... & ............. & ........ & n........... & ............... & ........ \\
\hline 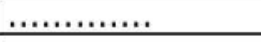 & ............. & ........ & . & ............. & ........ \\
\hline n.............. & n............... & ......... & n............... & n............... & .......... \\
\hline
\end{tabular}




\section{In de middag...}

Heb je gisteren lunch gehad of iets tussendoor in de middag gegeten?

- Ja Nee

Zo ja, heb je gisteren bij je lunch of tussendoor in de middag fruit of groente gegeten?

- Ja - Nee

Zo ja, wat voor fruit of groente? En hoeveel heb je daarvan gegeten?

Schrijf 1 als je 1 hele appel hebt gegeten, schrijf een half als je een halve appel hebt gegeten. Als jouw fruit of groente niet in de tabel staat, kun je dat in de tabel zelf invullen.

\begin{tabular}{|c|c|c|c|c|c|}
\hline \multicolumn{3}{|c|}{ Fruit in de middag } & \multicolumn{3}{|c|}{ Groente in de middag } \\
\hline Appel & & Stuk & Komkommer & & Schijfjes \\
\hline Banaan & $\ldots$. & Stuk & Snoeptomaatje & & Stuks \\
\hline Mandarijn & f........... & Stuk & Paprika & $\ldots$ & Reepjes \\
\hline Druiven & n.......... & Handje & Wortel & n..., & Stuks \\
\hline Gesneden fruit & f............ & Bakje & Gesneden groente & $\cdots$ & Bakje \\
\hline 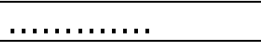 & f.............. & n......... & (2) & $\ldots$. & …..... \\
\hline & & f........ & & & f....... \\
\hline n............, & f............. & ........ & .............., & an.......... & n....... \\
\hline & & & & & \\
\hline
\end{tabular}




\section{In de avond...}

Heb je gisteren avondeten gehad of iets als snack na het avondeten gegeten?

- Ja Nee

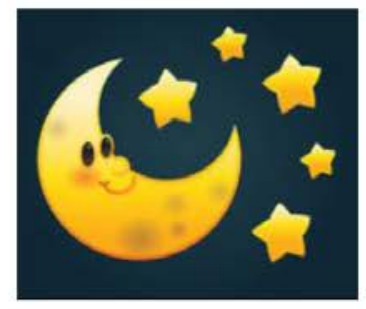

Zo ja, heb je gisteren bij je avondeten of als snack na het avondeten fruit of groente gegeten?

- Ja Nee

\section{Zo ja, wat voor fruit of groente? En hoeveel heb je daarvan gegeten?}

Schrijf 1 als je 1 hele appel hebt gegeten, schrijf een half als je een halve appel hebt gegeten. Als jouw fruit of groente niet in de tabel staat, kun je dat in de tabel zelf invullen.

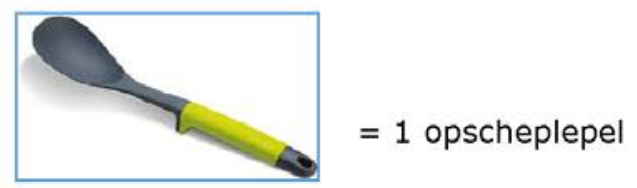

\begin{tabular}{|c|c|c|c|c|c|}
\hline \multicolumn{3}{|c|}{ Fruit in de avond } & \multicolumn{3}{|c|}{ Groente in de avond } \\
\hline Appel & & Stuk & Komkommer & & Schijfies \\
\hline Banaan & & Stuk & Sperziebonen & & Opscheplepels \\
\hline Mandarijn & & Stuk & Broccoli & & Opscheplepels \\
\hline Peer & $\ldots \ldots \ldots \ldots \ldots$ & Stuk & Bloemkool & ......... & Opscheplepels \\
\hline Frambozen & & Handje & Spinazie & & Opscheplepels \\
\hline Druiven & & Handje & Gemengde salade & & Opscheplepels \\
\hline ............... & ........ & $\ldots .$. & …........... & ....... & \\
\hline & & & $\ldots$. & & \\
\hline$\ldots \ldots$ & & & & & $\ldots$. \\
\hline & & & & & \\
\hline
\end{tabular}




\section{Eetgewoontes}

\section{Hoe vaak eet je vers fruit?}

- Nooit

- Minder dan $1 \times$ per week

- 1x per week

- 2-4x per week

- 5-6x per week

- $1 \times$ per dag

- 2x per dag

- Meer dan 2x per dag

Hoe vaak eet je salade met groente? Bijvoorbeeld een salade met sla, komkommer en tomaat.
- Nooit
- Minder dan $1 \times$ per week
- 1x per week
- 2-4x per week
- 5-6x per week
- 1x per dag
- 2x per dag
- Meer dan 2x per dag

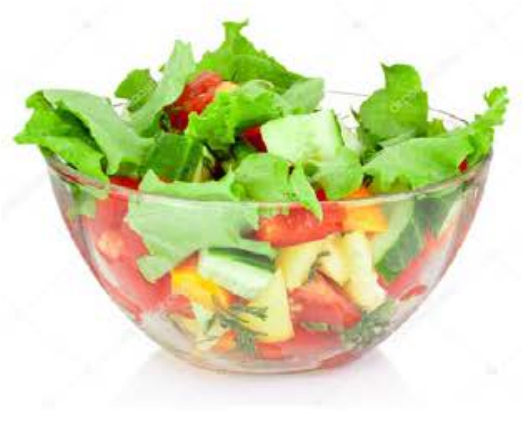


Hoe vaak eet je rauwe groente? Bijvoorbeeld een snoeptomaatje.

- Nooit

- Minder dan $1 \times$ per week

- $1 x$ per week

- 2-4x per week

- 5-6x per week

- 1x per dag

- 2x per dag

- Meer dan 2x per dag

Hoe vaak eet je aardappelen?

- Nooit

- Minder dan 1x per week

- 1x per week

- 2-4x per week

- 5-6x per week

- 1x per dag

- 2x per dag

- Meer dan 2x per dag

Hoe vaak eet je gekookte groente (aardappelen horen hier niet bij!)

- Nooit

- Minder dan 1x per week

- 1x per week

- 2-4x per week

- 5-6x per week

- 1x per dag

- 2x per dag

- Meer dan 2x per dag 


\section{Wat krijg jij mee van huis?}

Hoe vaak krijg je fruit of groente mee van huis?

- Elke dag

- 3-4x per week

- 2-3x per week

- 1x per week

- Nooit

Hoe vaak krijg je snoep of koek mee van huis?

- Elke dag

- 3-4x per week

- 2-3x per week

- 1x per week

- Nooit

Hoe vaak krijg je frisdrank of limonade mee van huis?

- Elke dag

- 3-4x per week

- 2-3x per week

- $1 x$ per week

- Nooit 


\section{Vragen over eten...}

Kijk je wel eens op een verpakking welke ingrediënten er in producten zitten?

- Ja, altijd

- Ja, meestal wel

- Soms wel, soms niet

- Nee, meestal niet

- Nee, nooit

Als je zelf mocht kiezen, wat neem je dan het liefst mee naar school voor in de kleine pauze?

Omcirkel één antwoord:

- Snoep

- Chips

- Fruit

- Boterham

- Groente

- Koek

- Anders, namelijk

\section{Help je je ouders/verzorgers wel eens met koken?}

- Elke dag

- 3-4x per week

- 2-3x per week

- 1x per week

- Soms

- Nooit 
Vinden je ouders/verzorgers gezond eten belangrijk?
- Ja
- Een beetje
- Nee

Vraag je je ouders/verzorgers wel eens om bepaalde soorten groente of fruit te kopen?
- Ja
- Soms
- Nee

Wordt er bij jou thuis over gezond eten gepraat?
- Ja
- Soms
- Nee

Gebruik je wel eens een recept om mee te koken?
- Ja
- Soms
- Nee

Maak je wel eens samen met anderen eten klaar?
- Ja
- Soms
- Nee

Maak je wel eens een gezonde snack?
- Ja
- Soms
- Nee

Heb je alle vragen ingevuld?

Dan ben je kla ar!

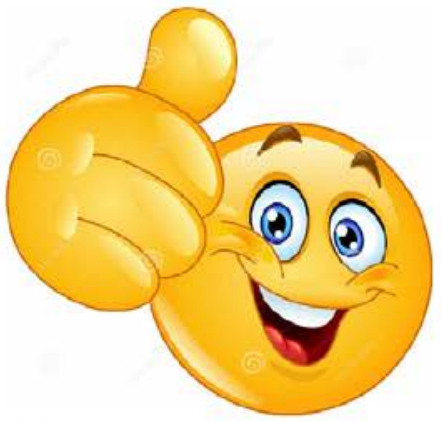

Dankjewel voor het invullen! 


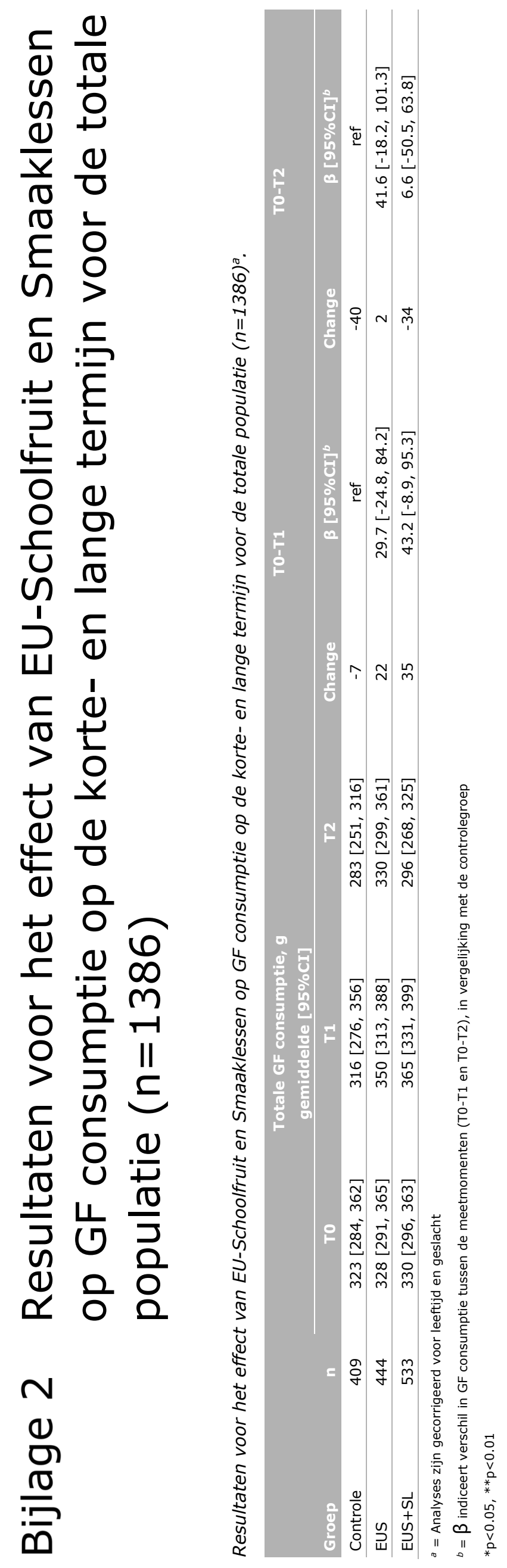




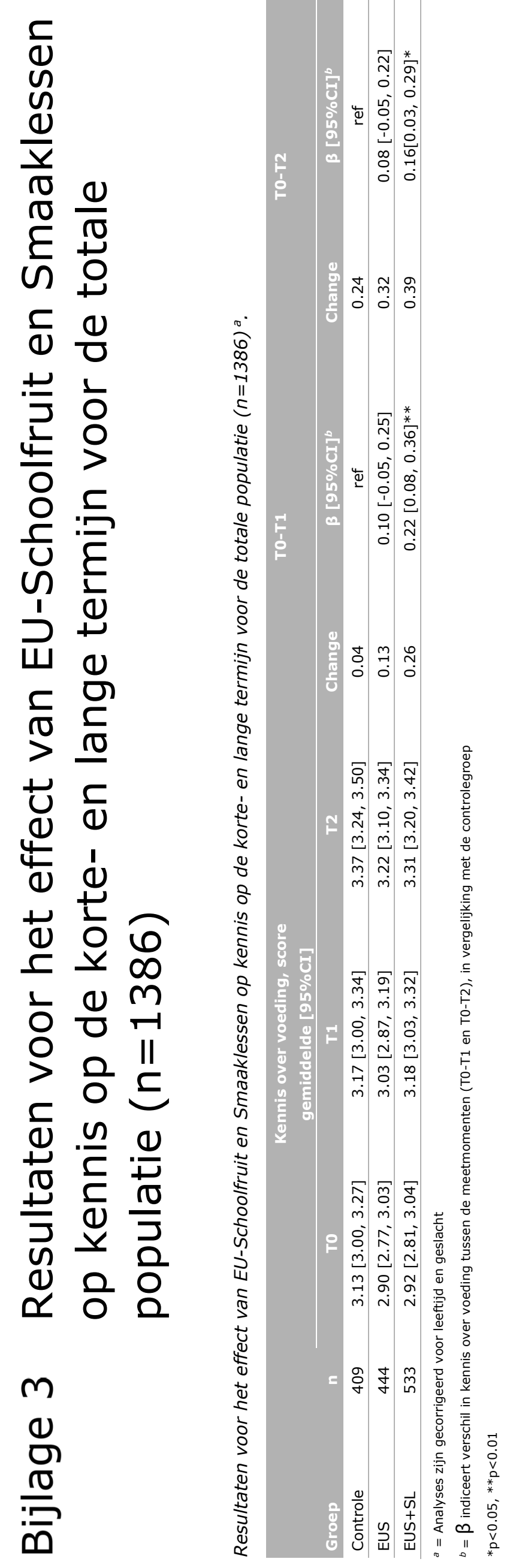



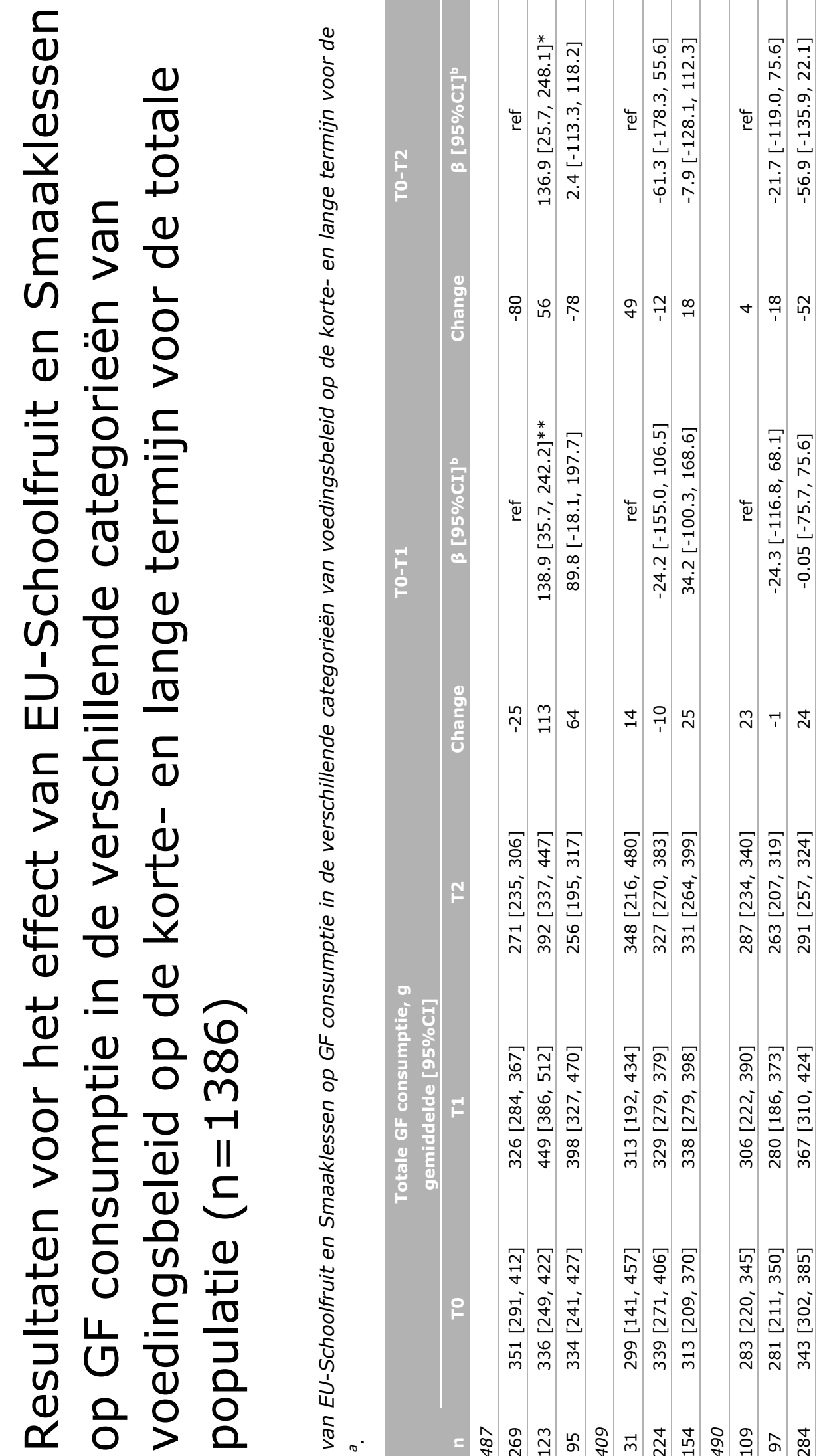

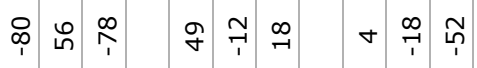

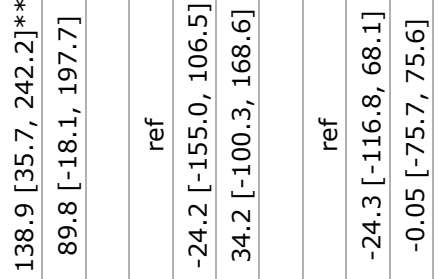

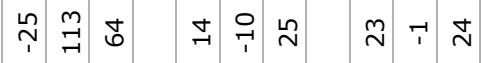
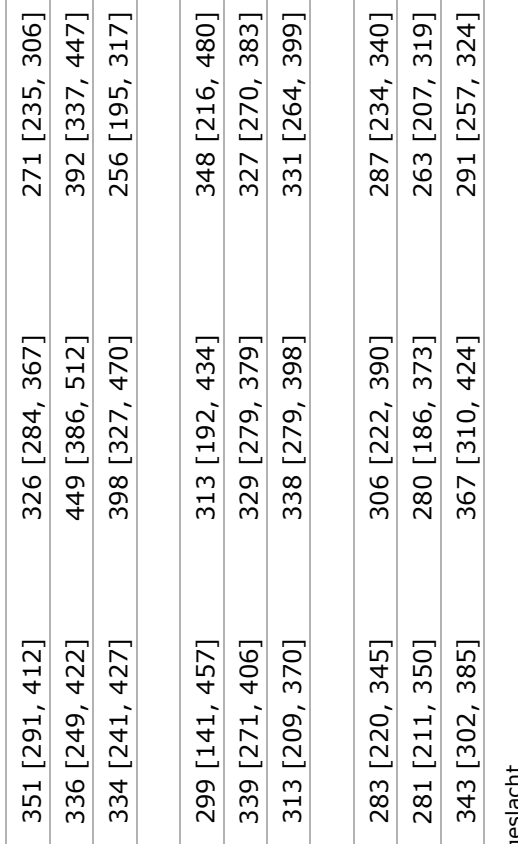

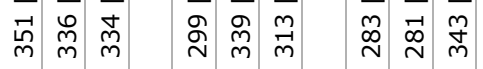

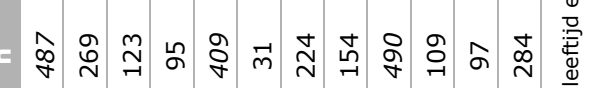
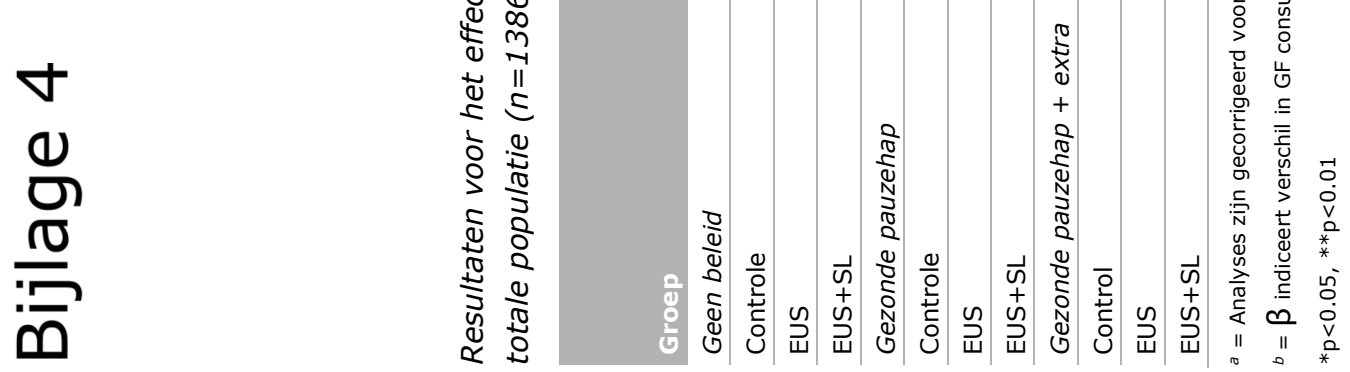


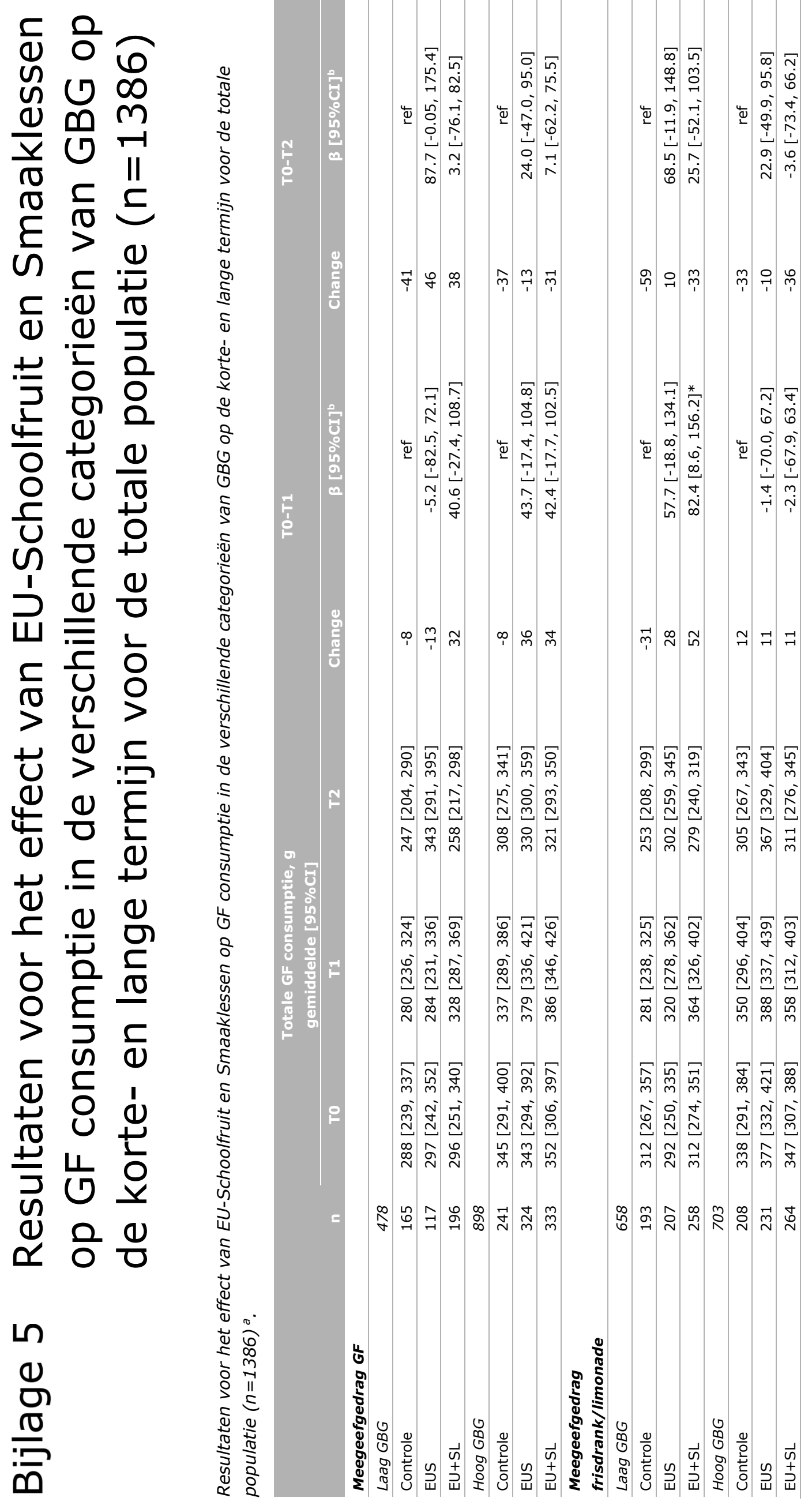




\begin{tabular}{|c|c|c|c|c|c|c|c|}
\hline 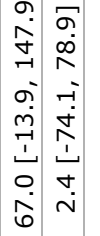 & 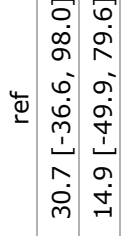 & 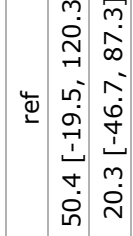 & 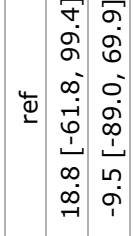 & 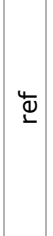 & 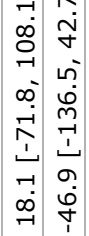 & $\mathbb{L}$ & 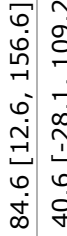 \\
\hline
\end{tabular}

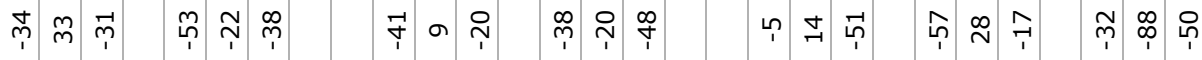

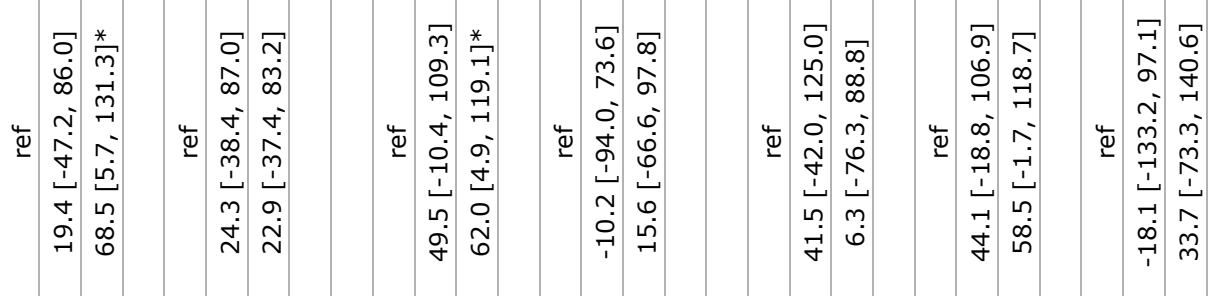

뉭

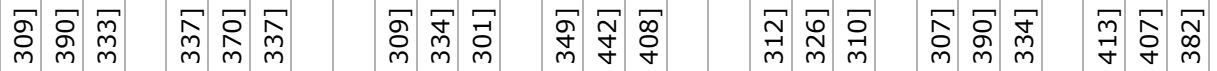

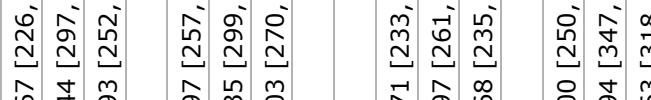

స̇ं

ڤ્仓

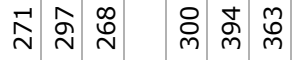

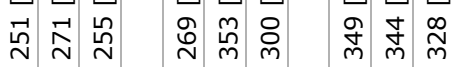

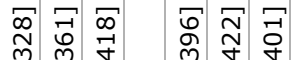

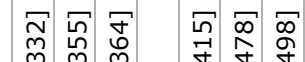

ป্র

文

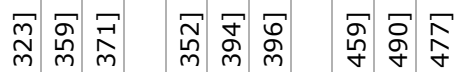

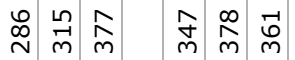

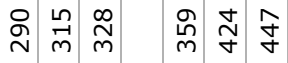

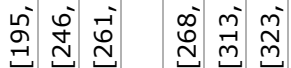

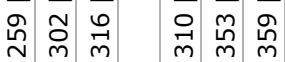

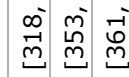

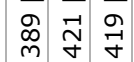

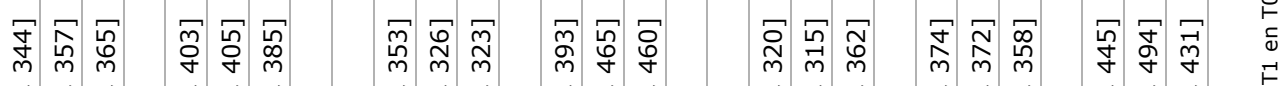




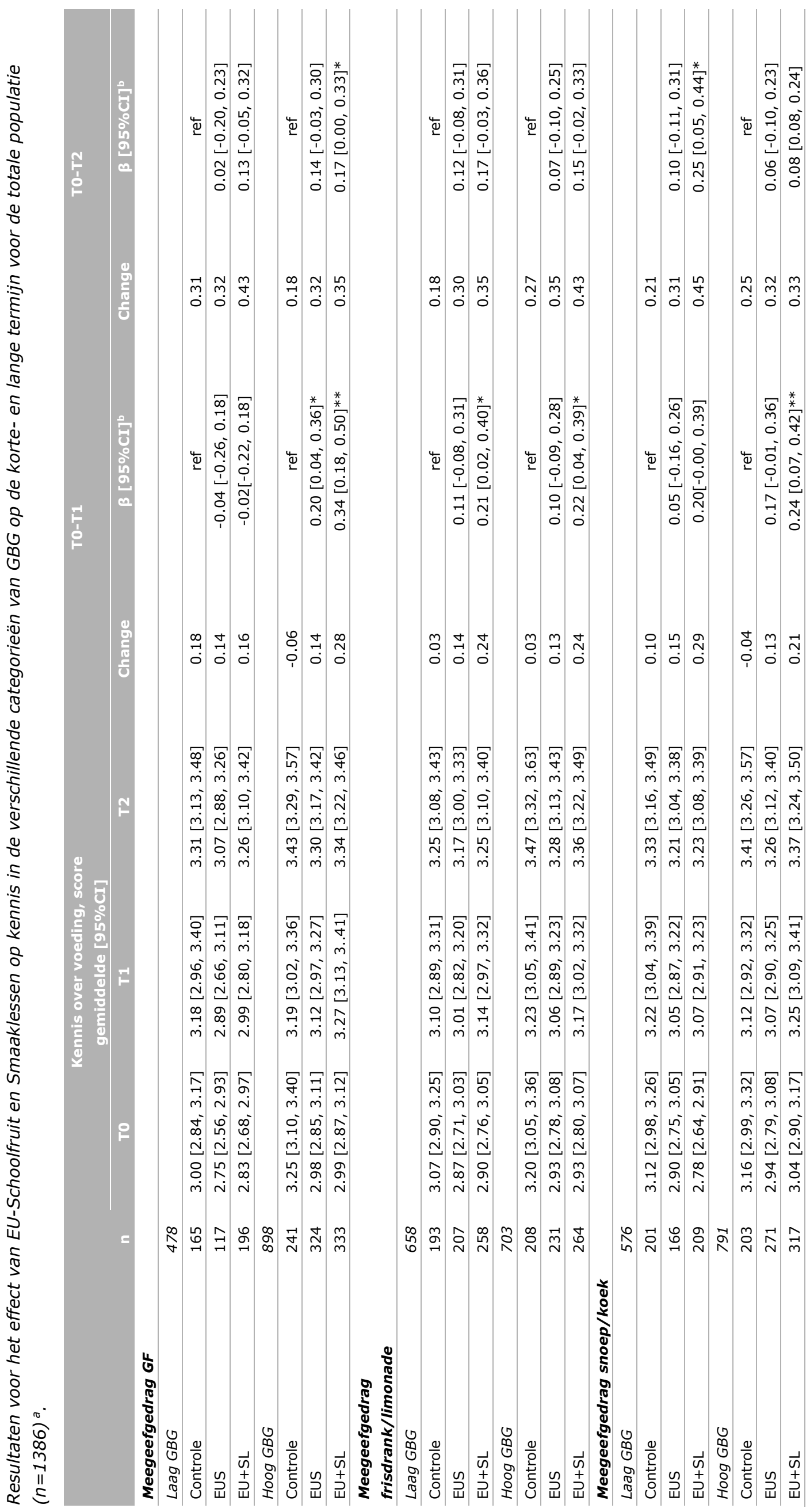




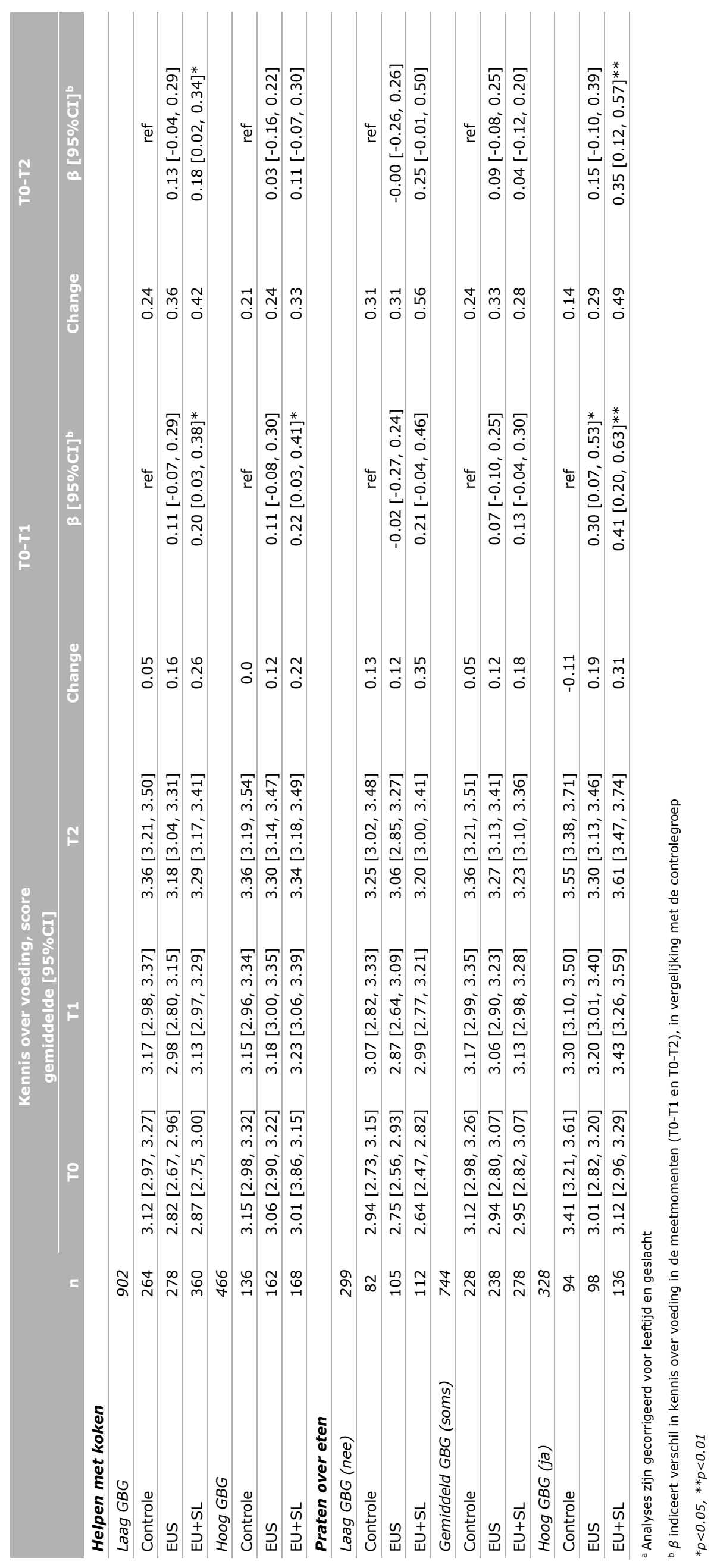


Wageningen University \& Research Leerstoelgroep Consumptie en Gezonde Leefstijl

Postbus 8129

6700 EV Wageningen

T 0317483505

office.chl@wur.nl

www.wur.nl
De missie van Wageningen University \& Research is 'To explore the potential of nature to improve the quality of life'. Binnen Wageningen University \& Research bundelen Wageningen University en gespecialiseerde onderzoeksinstituten van Stichting Wageningen Research hun krachten om bij te dragen aan de oplossing van belangrijke vragen in het domein van gezonde voeding en leefomgeving. Met ongeveer 30 vestigingen, 5.000 medewerkers en 12.000 studenten behoort Wageningen University \& Research wereldwijd tot de aansprekende kennisinstellingen binnen haar domein. De integrale benadering van de vraagstukken en de samenwerking tussen verschillende disciplines vormen het hart van de unieke Wageningen aanpak. 



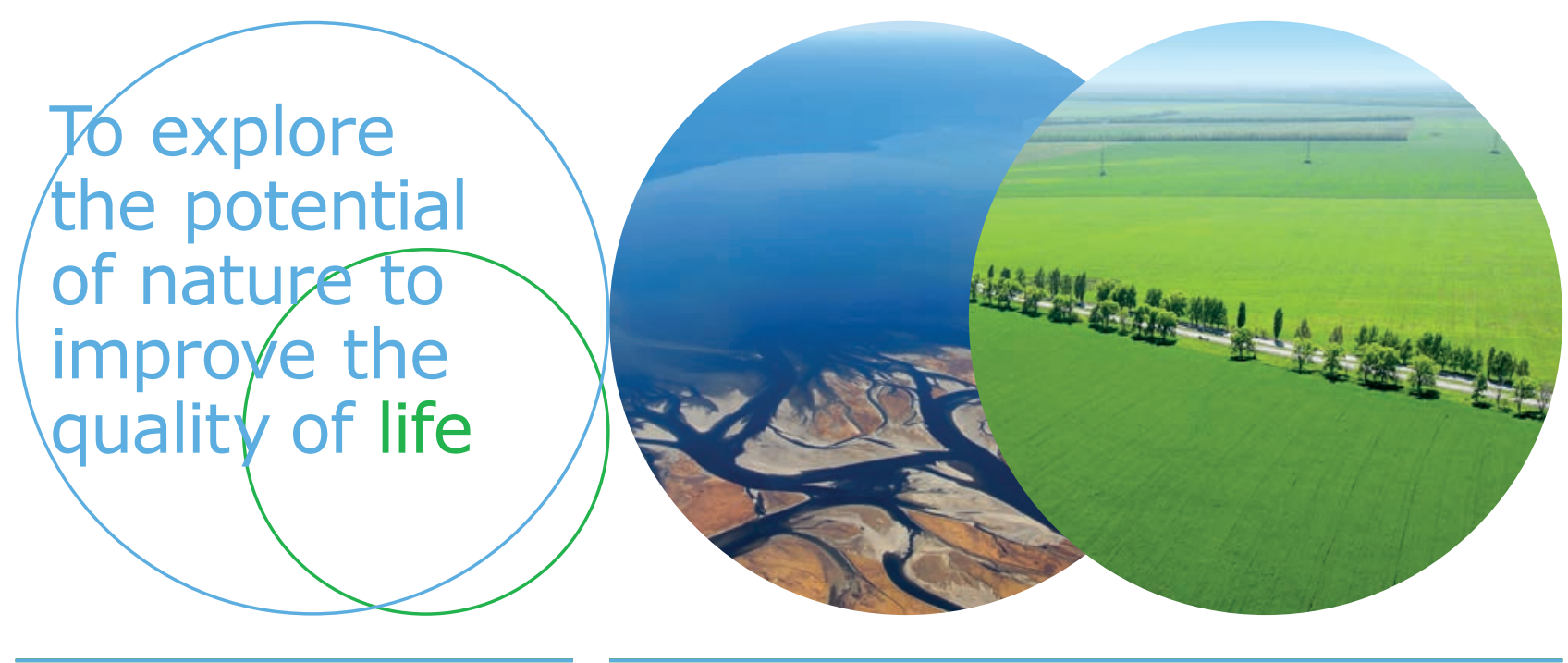

Wageningen University \& Research Leerstoelgroep Consumptie en Gezonde Leefstijl Postbus 8129 6700 EV Wageningen T 0317483505 office.chl@wur.nl www.wur.nl
De missie van Wageningen University \& Research is 'To explore the potential of nature to improve the quality of life'. Binnen Wageningen University \& Research bundelen Wageningen University en gespecialiseerde onderzoeksinstituten van Stichting Wageningen Research hun krachten om bij te dragen aan de oplossing van belangrijke vragen in het domein van gezonde voeding en leefomgeving. Met ongeveer 30 vestigingen, 5.000 medewerkers en 12.000 studenten behoort Wageningen University \& Research wereldwijd tot de aansprekende kennisinstellingen binnen haar domein. De integrale benadering van de vraagstukken en de samenwerking tussen verschillende disciplines vormen het hart van de unieke Wageningen aanpak. 